\title{
THE REVEAL \\ Voyeurism and Society
}

by

\author{
Paolo Milanes
}

A thesis submitted to the Faculty of Graduate and Postdoctoral Affairs in partial fulfillment of the requirements for the degree of

Master of Architecture

in

M.ARCH (PROFESSIONAL)

Carleton University

Ottawa, Ontario

(C) 2011

Paolo Milanes 


$\begin{array}{ll}\begin{array}{l}\text { Library and Archives } \\ \text { Canada }\end{array} & \begin{array}{l}\text { Bibliothèque et } \\ \text { Archives Canada }\end{array} \\ \begin{array}{l}\text { Published Heritage } \\ \text { Branch }\end{array} & \begin{array}{l}\text { Direction du } \\ \text { Patrimoine de l'édition }\end{array} \\ \begin{array}{l}\text { 395 Wellington Street } \\ \text { Ottawa ON K1A 0N4 } \\ \text { Canada }\end{array} & \begin{array}{l}395, \text { rue Wellington } \\ \text { Ottawa ON K1A ON4 } \\ \text { Canada }\end{array}\end{array}$

Your file Votre reférence ISBN: 978-0-494-83190-8 Our file Notre référence ISBN: 978-0-494-83190-8

NOTICE:

The author has granted a nonexclusive license allowing Library and Archives Canada to reproduce, publish, archive, preserve, conserve, communicate to the public by telecommunication or on the Internet, loan, distribute and sell theses worldwide, for commercial or noncommercial purposes, in microform, paper, electronic and/or any other formats.

The author retains copyright ownership and moral rights in this thesis. Neither the thesis nor substantial extracts from it may be printed or otherwise reproduced without the author's permission.
AVIS:

L'auteur a accordé une licence non exclusive permettant à la Bibliothèque et Archives Canada de reproduire, publier, archiver, sauvegarder, conserver, transmettre au public par télécommunication ou par l'Internet, prêter, distribuer et vendre des thèses partout dans le monde, à des fins commerciales ou autres, sur support microforme, papier, électronique et/ou autres formats.

L'auteur conserve la propriété du droit d'auteur et des droits moraux qui protège cette thèse. $\mathrm{Ni}$ la thèse ni des extraits substantiels de celle-ci ne doivent être imprimés ou autrement reproduits sans son autorisation.
In compliance with the Canadian Privacy Act some supporting forms may have been removed from this thesis.

While these forms may be included in the document page count, their removal does not represent any loss of content from the thesis.
Conformément à la loi canadienne sur la protection de la vie privée, quelques formulaires secondaires ont été enlevés de cette thèse.

Bien que ces formulaires aient inclus dans la pagination, il n'y aura aucun contenu manquant.

\section{Canadä}




\section{Please note:}

The information from the original title page for this thesis has been transferred to the Carleton University Library's standard title page template for theses/research essays due to legibility concerns. 


\section{THE REVEAL}

Voyeurısm and Society

PAOLO MILANES

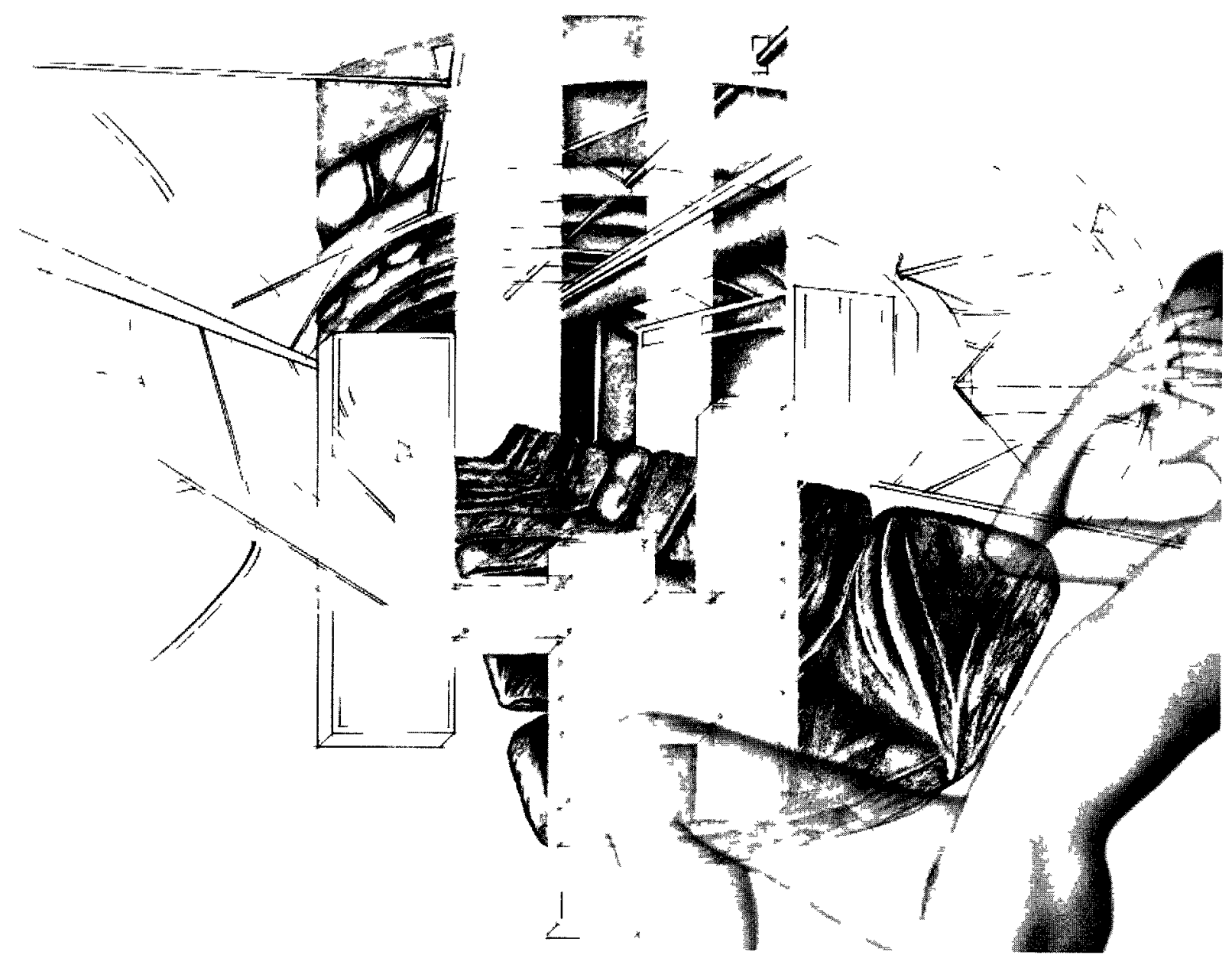

A thesis submitted to the Faculty of Graduate Studies and Research in partial fulfillment of the requirements for the degree of

\section{MASTER OF ARCHITECTURE $M$ ARCH (PROFESSIONAL)}

Carleton University School of Architecture Ottawa, Canada Paolo Milanes (C)2011 
This thesis investigates voyeurism in a social context, both within the public and the private realm. Voyeurism in today's society devalues privacy for the privilege of spectating scenarios, interactions, or discussions of others. The research aimed at clarifying misconceptions about voyeurism focuses on the engagement of voyeurs and exhibitionists. The importance of focusing on the interaction between the participant and the object is to ensure the direct impact of voyeurism as a social construct. Literary works, along with art and architectural case studies serve as a framework for means of seducing a participant to engage voyeuristic scenarios in an otherwise mundane environment. These qualities are required in order to address the issue of the chosen site where, on observation, the site is lacking any social engagement with the public. 


\section{Acknowledgements}

This thesis would not have been possible without my best friends to distract me from it and keep me sane. In particular, Francesca, Mina, Olya, Sebastian - thanks for all the laughs, the adventures, and the tequila / wine nights. To the DRS crew, you have made studio a lot of fun. To Jaclyn, Nadine, Vedrana, and Veronica: thanks for all the food, shelter, and gossip over the years. To Cammie, Jessica, and Sara, thanks for keeping me company in The Boudoir as we frantically tried to meet deadlines.

I would like to thank Dr. Stephen Fai for his direction, assistance, and guidance. I also wish to thank my previous professors who have all helped and taught me a great deal. Namely, never to create garbage pizzas, always be critical of criticality, and to show me, don't tell me. To Mark and Dave, thanks for putting up with me in your respective workshops.

To all the students of architecture who I've encountered in the last six years, many thanks for your insightful comments, creativity, and inspirations. You will be greatly missed.

Finally, words alone cannot express my gratitude to my family. For my parents who supported my decisions, and my sister and my brother who was always there. Thank you. 


\section{Table of Gontents}

Abstract

$i$

Acknowledgements

ii

List of Figures

iv

The Sentiment

Introducing Eroticism

The Expectation

6

Explaining Voyeurism

The Pursuit

Marcel Duchamp's Use of Desire and Voyeurism

The Peep Show

Portrayal of Voyeurism in Films

The Glosed Curtain

Voyeuristic Spaces in Architecture

The Badeschiff

Voyeurism in a Public Setting

The Exhibitionists

Using Voyeurism in the Spotlight

The Seduction

Voyeuristic Documentation

The Proposal

Engaging the Voyeurs

Appendix A

Process Work

Bibliography

Works Cited 


\section{List of Figures}

Fig. 1: Lady Godiva.

John Collier. Lady Godiva. 1898. Painting. <http://wikimedia.org>

Fig. 2: $\quad$ Eros

Caravaggio, Amor Vincit Omnia. 1602. Oil on canvas. Staatliche Museen, Berlin

Fig. 3: $\quad$ Woman with Camera.

Alfred Johnston, Woman with Camera. 1920. Photograph. <http://wikimedia.org>

Fig. 4: Tube TV.

Belweder. 2007. Photograph. <http://wikimedia.org>

Fig. 5: $\quad$ The Bride Stripped Bare by Her Bachelors, Even.

Marcel Duchamp, The Bride Stripped Bare by Her Bachelors, Even. 1915-23. Sculpture.

Philadelphia Museum of Art, Philadelphia

Fig. 6: $\quad$ The Large Glass.

The Large Glass. Photograph. <http://culturalartspddc.blogspot.com/2010_04_01_archive. html>

Fig. 7: . Étant Donnés - Exterior.

Marcel Duchamp, Given: 1 The Waterfall, 2. The Illuminating Gas. 1946-66. Sculpture.

Philadelphia Museum of Art, Philadelphia

Fig. 8: Étant Donnés - Interior.

Marcel Duchamp, Given: 1 The Waterfall, 2. The Illuminating Gas. 1946-66. Sculpture.

Philadelphia Museum of Art, Philadelphia

Fig. 9: Étant Donnés - Visitor.

Etant Donnés on View. Photograph. 2009. <http://theartblog.org>

Fig. 10: Jeffrey looking through the closet doors.

David Lynch, Blue Velvet. 1986. Film still.

Fig. 11: Frank on top of Dorothy.

David Lynch, Blue Velvet. 1986. Film still.

Fig. 12: Moller House - Elevation.

Adolf Loos. Moller House. 1928. Photograph.

Fig. 13: $\quad$ Moller House - Street façade.

Adolf Loos. Moller House. 1928. Photograph.

Fig. 14: Josephine Baker

French Walery. Josephine Baker in Banana Skirt. 1927. Photograph. <http://wikimedia.org>

Fig. 15: Josephine Baker House

Adolf Loos. Josephine Baker House. 1928. Photograph.

Fig. 16: Josephine Baker House Plans

Adolf Loos. Josephine Baker House. 1928. Illustration.

Flg. 17: The Badeschiff during the summer.

C-Reel.com. Badeschiff in the Summer. 2004. Photograph. <http://flickr.com>

Fig. 18: The Badeschiff during the winter.

Thomas Brauner. Winter Badeschiff. 2010. Photograph. <http://flickr.com>

Fig. 19: The Badeschiff showing selective transparency.

H. Füller. Badeschiff. 2010. Photograph. <http://flickr.com>

Fig. 20: Aerial view of Elgin and Laurier, Ottawa

Google Maps. 2007. Photograph. <http://maps.google.com> 
Fig. 21: $\quad$ First Baptist Church

Library and Archives Canada. Photograph. <www.collectionscanada.gc.ca>

Fig. 22: First Baptist Church, west façade

Library and Archives Canada. Photograph. <www.collectionscanada.gc.ca $>$

Fig. 23: North parking lot - daytime.

Author. 2010. Photograph.

Fig. 24: North parking lot - evening. Author. 2010. Photograph.

Fig. 25: First Baptist Church - Interior, sanctuary.

Author. 2010. Photograph.

Fig. 26: First Baptist Church - Interior, organ gallery.

Author. 2010. Photograph.

Fig. 27: Day and night conditions from Elgin Street.

Author. 2010. Photograph.

Fig. 28: Day and night conditions from Laurier Street.

Author. 2010. Photograph.

Fig. 29: Elevation from Laurier Street

Author. 2010. Collage

Fig. 30: Main entrance lobby.

Author. 2011. Rendering.

Fig. 31: Second Floor - View from stair landings.

Author. 2011. Rendering.

Fig. 32: View of hallway and sushi bars

Author. 2011. Rendering.

Fig. 33: Sushi bar.

Author. 2011. Rendering.

Fig. 34: Third Floor - Circulation

Author. 2011. Rendering.

Fig. 35: Public swimming pool with fitness facility above.

Author. 2011. Rendering.

Fig. 36: Ground Floor - Hallway for public visitors.

Author. 2011. Rendering.

Fig. 37: Columns extend downwards inside the swimming pool.

Author. 2011. Rendering.

Fig. 38: Typical stair detail.

Author. 2011. Rendering.

Fig. 39: Typical stair detail - Angle view.

Author. 2011. Rendering.

Fig. 40: Typical stair detail - Bottom view.

Author. 2011. Rendering.

Fig. 41: Elevation at night

Author. 2011. Rendering.

Fig. 42: Elevation showing illumination at night

Author. 2011. Rendering.

Fig. 43: First floor plan.

Author. 2011. Illustration.

Fig. 44: Second floor plan.

Author. 2011. Illustration. 
Fig. 45: Third floor plan.

Author. 2011. Illustration.

Fig. 46: Longitudinal section.

Author. 2011. Illustration.

Fig. 47: Section through public pool and Allstream office building. Author. 2011. Illustration.

Fig. 48: Section through restaurant and main lobby. Author. 2011. Illustration. 
The name "Peeping Tom," refers to a voyeur and originates from an $11^{\text {th }}$ century legend. The legend revolves around Lady Godiva (Fig. 1), an Anglo-Saxon noblewoman married to Leofric, the Earl of Mercia. They lived in the town of Coventry where the people were suffering grievously due to the Earl's oppressive taxation. Lady Godiva took pity upon the citizens and appealed to her husband to remit the taxes. The Earl refused but Lady Godiva was insistent and, weary of her nagging, the Earl accepted her request on one condition. Since the Lady Godiva was a patron of the arts, the Earl pointed out to her that the Greeks and Romans viewed a human body as one of the highest expressions of perfection in nature. ${ }^{1}$ The price she would have to pay in order to abolish the town's taxes would be to ride naked through the marketplace in Coventry at mid-day. Lady Godiva agreed. However, she issued a proclamation to the citizens saying that everyone must stay indoors and shut their windows as she rode naked, on a horse, through the town. One citizen disobeyed. The citizen, a tailor named Tom, created holes in his shutters that allowed him to peek through in order to see the naked Lady as she rode by.

The legend of the Peeping Tom is now an iconic example of voyeurism. In Coventry, there is a statue of Tom, located in the city's Cathedral Lanes Shopping Centre. ${ }^{2}$ The tale

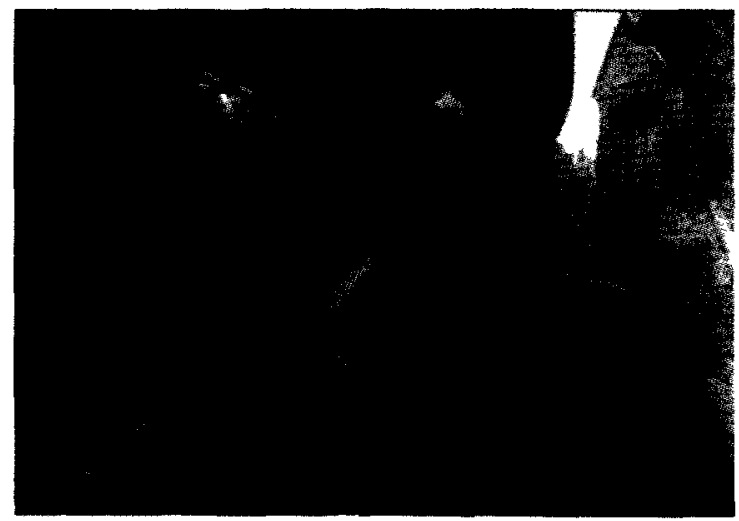

Fig. 1: Lady Godiva. exemplifies voyeurism through characters who are both spectators and participants; in the tale, Lady Godiva is, albeit under duress, the willing exhibitionist, and Tom is the willing voyeur. The tale also demonstrates the fact that voyeurism is a socially unacceptable behaviour and that it may possibly lead to undesired consequences; in some versions of the tale, Peeping Tom ends up being

1 "Lady Godiva: The Naked Truth." BBC News. Web. 05 May 2011. <http://news.bbc.co.uk/2/hi/in_ depth/uk/2000/newsmakers/1507606.stm>.

2 "Lady Godiva." Historic UK. Web. 05 May 2011. <http://www.historic-uk.com/CultureUK/LadyGo diva.htm>. 
struck blind. ${ }^{3}$ But is voyeurism still socially unacceptable? Is it an act that is perhaps misunderstood? To understand how voyeurism works in our present day culture and society, we must consider it under the broader umbrella of eroticism.

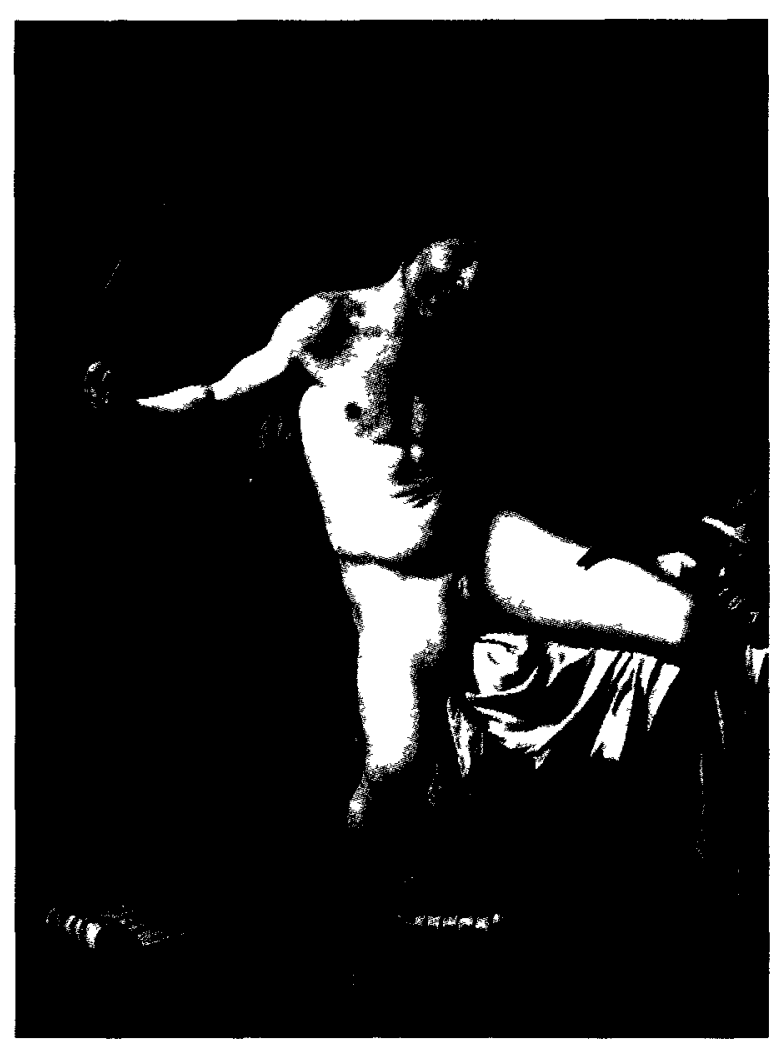

Fig. 2: Eros.
The word "erotic" is derived from Eros (Fig. 2.), a character in Greek Mythology who was the primordial god of sexual love and beauty. Eros denotes "want, lack, or desire for that which is missing. The lover wants what he does not have. It is by definition impossible for him to have what he wants if, as soon as it is had, it is no longer wanting." ${ }^{4}$ Eroticism thus becomes an issue of desire for an object. However, an object can have a diminishing desirability. Adrian Piper, a conceptual artist and analytic philosopher, explains the diminishing desirability of an object through the term "marginal utility." As an example, suppose there is a desire to quench one's thirst. The first glass of water is the most intensely enjoyable and thus, has the highest utility. The second glass of water has a lower utility as it is less enjoyable than the first. The third glass will be even less enjoyable, and perhaps even painful and unpleasant if the thirst is already quenched. Eroticism is present when fulfillment is prolonged; when desire is satiated, the utility is diminished and eroticism disappears.

3 Daniel Donoghue, Lady Godiva: a Literary History of a Legend, (Malden, MA: Blackwell Pub., 2003) 92.

4 Anne Carson, Eros the Bittersweet: an Essay, (Princeton: Princeton UP, 1986) 10. 
Adrian Piper argues that objects have a certain "mystery" around them. She describes this "mystery of the objects" as the objects containing "their own inner workings and unique qualities." To view these objects is to search out and understand the objects' peculiar logic and structure in order to discern whatever makes these objects unique. That is where voyeurism comes into play. We look, we view, we gaze, because we are attracted to the mystery of the object. We wish to understand or solve the mystery surrounding the object. As such, we view objects "in order to satisfy our desire for new and innovative perceptual experience, or our desire to expand our perceptual sensitivity to our surroundings, or for aesthetic or intellectual stimulation." 6

In the tale of Lady Godiva and Peeping Tom, Tom becomes a voyeur because he is attracted to the Lady Godiva: he wishes to be stimulated, albeit not intellectually, but physically. Carson argues that society "sets a high value on both the chastity and the prolificacy of the female." In the case of Peeping Tom, Lady Godiva is an object with a high value in terms of attractiveness and social status and is thus seductively unattainable. Tom realizes this, and understands that the closest he would come to attaining her would be through that peephole. Nevertheless, voyeurism runs deeper than just bodily and sexual desires.

French novels in the seventeenth, eighteenth, and nineteenth century exhibit similar themes as those present in the tale of Lady Godiva. In her book, Telling Glances: Voyeurism in the French Novel, Dorothy Kelly summarizes the plots of many French novels of the period.

"A man desires a woman who is enigmatic and unobtainable. He not only desires to possess her; he also experiences an irresistible need to see her and to understand her, to know exactly what she is, or what she desires. But since this information remains hidden, the man resorts to spying on her in order to obtain the information; he resorts to an act of voyeurism."

$5 \quad$ Adrian Piper, "Performance and the Fetishism of Art Objects," in The Nature of Art: an Anthology, ed. Thomas E. Wartenberg (Fort Worth: Harcourt College, 2002), 255.

6 Piper, 258.

7 Carson, 23.

8 Dorothy Kelly, Telling Glances: Voyeurism in the French Novel (New Brunswick, NJ: Rutgers University Press, 1992) 1. 
The connection between voyeurism in French literature in another period and our society is explained by Kelly, who suggests, "much of the voyeurism in the French novel, as well as much of psychoanalysis, focuses on quests for truth and knowledge, as well as searches for identity and desire." The idea put forth by Kelly is that although voyeurs in French novels aim to gain sexual knowledge, individuals in present day society become voyeurs in the hope that they may learn something about themselves or others. She concludes, "We strive to learn what truth and reality are in our mediated, jump cut world by watching others." ${ }^{10}$

Clay Calvert, in his book Voyeur Nation: Media, Privacy, and Peering in Modern Culture, argues that voyeurism at the beginning of the twenty-first century extends beyond the body and can be understood as "the consumption of revealing images of and information about others' apparently real and unguarded lives, often yet not always for the purposes of entertainment but frequently at the expense of privacy and discourse..." ${ }^{\text {"11 }}$ For Calvert, "revealing" includes "aspects of disclosure and enlightenment that may occur." ${ }^{12}$ As well, he chooses the phrase "apparently real and unguarded lives" to refer to images or scenarios that are purported to be spontaneous in nature. The phrase "often yet not always for purposes of entertainment" is used because the motivations for partaking in voyeurism extend beyond simple entertainment. Finally, the phrase "frequently at the expense of privacy and discourse" describes what we give up or sacrifice in order to be voyeurs. In voyeurism, privacy is devalued. Instead of interaction and discussion, preference is given to spectating. Although not all acts of voyeurism are without consent, other cases include individuals who willingly let others watch. These people, exhibitionists, sacrifice their privacy with consent.

In Lady Godiva's tale, one can observe multiple boundaries and the transgression of those boundaries. First, there is the issue of Lady Godiva exposing herself to the public. In Anglo-Saxon culture of the 11th century, nakedness in public was considered taboo. So for Lady Godiva to expose herself means that she knowingly must cross a certain social boundary in order to achieve her wish. Second, there is the boundary between Lady Godiva and the Earl. The Lady Godiva is the Earl's wife, so why does he wittingly embarrass and shame her to the public? Thirdly, Lady $9 \quad$ Kelly, 2.

10 Clay Calvert, Voyeur Nation: Media, Privacy, and Peering in Modern Culture (Boulder, CO: West view, 2000) 39.

11 Calvert, 2-3.

12 Calvert, 3. 
Godiva arranged that the public must remain in their homes and close their shutters. Peeping Tom defied this rule and decided to peek at Godiva's naked body. It was important for Tom to remain anonymous. Anonymity allows for the voyeur (Tom) to view the object (Godiva) without being noticed or seen and gives both of them a sense of security. It also allows Tom to project and attach his personal fantasies onto Godiva. 


\section{The Expectation Explaining Voyeurism}

This thesis investigates voyeurism in a social context, both within the public and the private realm. Can voyeurism be used in architecture to satiate society's desire for innovative perceptual experiences and surroundings? What would be the effects of this approach and would it be a viable way to invoke social engagement through architecture? The following chapters investigate the relationships and encounters between individuals as both spectators and participants in voyeuristic scenarios, to answer these questions and inform a framework for a voyeuristic architectural proposal.

Following Clay Calvert, I argue that North American Culture is heavily immersed in voyeurism. Turn on the television and we are exposed to a myriad of shows - some recreated, some not - that quench the audience's voyeuristic thirst for the sensational details of the lives of others. The audience does not even have to interact with these "others." Certain highly successful shows capture the realistic and unscripted moments of life as it unfolds, portraying details of others' private lives. Take for example the show COPS - the reality show where camera crews follow police officers, sheriffs, and deputies who patrol and perform police activities. ${ }^{13}$ Yet, television is not the only medium through which voyeurism reaches us every day. Technological development in electronics - spy cameras, video cameras, digital cameras, and computers just to name a few - have made other forms of voyeurism more intrusive and more pervasive.

Calvert calls to attention that, "[culture] has, depending on one's point of view, evolved or devolved into a culture of mediated voyeurism - a culture that values watching electronic images of other people's private and revealing moments, especially those that

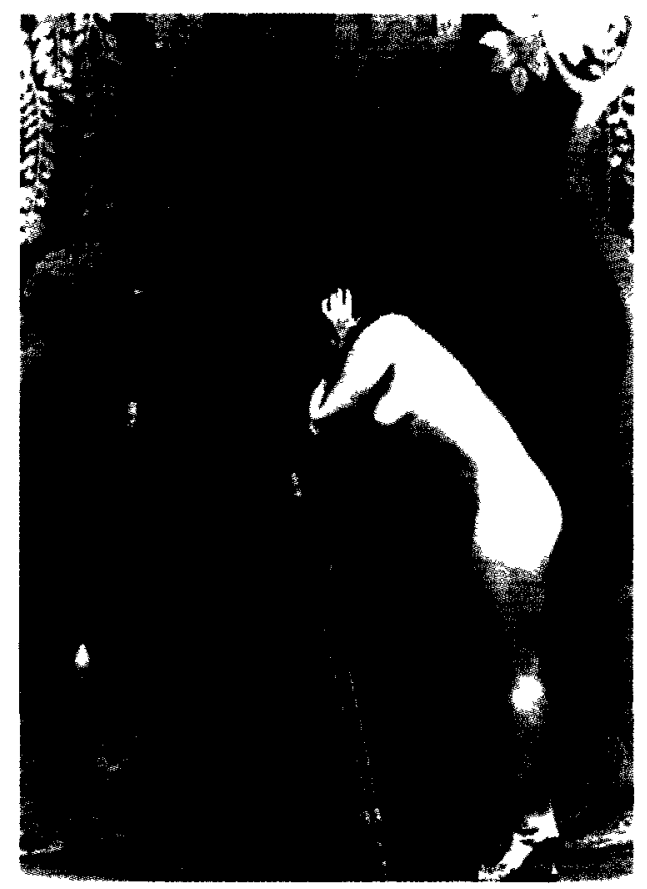

Fig. 3: Woman with Camera.

13 Ben Grossman. "Bad Boys = Big Money," Broadcasting \& Cable. 30 July 2005. Web. 28 July 2011. $<$ http://www.broadcastingcable.com/article/159548-Bad_Boys_Big_Money.php>. 
are sordid and sensational or simply strange and unusual." ${ }^{14}$ What the audience or voyeur possesses is the urge to view or perceive something that is both alien and intimate - something that is distanced from the voyeur's everyday life. Essentially, voyeurism sacrifices the privacy of others for the pleasure of the voyeur. Interestingly enough, privacy is a social construction. Our ideas of what is public and private are dictated and shift with culture. Privacy as a concept is "created, maintained, and changed by members of society, including, most notably, journalists and others in the media. Our own definition of what information will vary... pushed along by the media's actions in giving publicity to facts some would deem private." ${ }^{15}$ What society or culture considered taboo or private in the 1800 's is vastly different from what we consider presently, and it is still changing. Censorship,

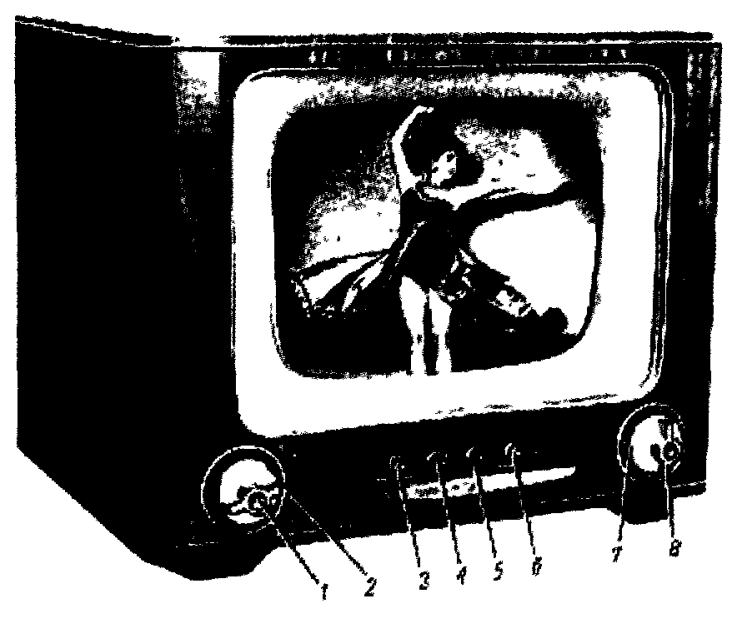

Fig. 4: Tube TV. rules, regulations, and political correctness are on the rise. ${ }^{16}$ Journalists are not the only ones with this influence; anyone, professionals, family members, laymen, or lawmakers can and will have different notions of what privacy is. ${ }^{17}$ Thus, privacy can be thought of as "the power and ability of an individual to control the flow and dissemination of information about himself or herself." ${ }^{18}$ But what happens if the power shifts and it is granted to the voyeur?

Calvert, 19-20.

Calvert, 78-79.

Calvert, 13.

Calvert, 79.

Calvert, 79. 


\section{The Pursuit \\ Marcel Duchamp's Use of Desire and Voyeurism}

Marcel Duchamp, a French artist who was closely associated with the Surrealist and Dadaist movements in art, understood that engagement and interaction were critical in art. He described art as having two poles: the object and the subject who views the object. Duchamp realized that the spectator contributes to the creative act of the artist by deciphering and interpreting the artwork. As Donald Kuspit explains Duchamp's notion: "It was the subject who made the object into art, that is, gave it esthetic and expressive value, however ironically. The subject is implicitly a male voyeur projecting his erotic and aggressive fantasies onto the object - a peeping Tom, as it were." ${ }^{19}$

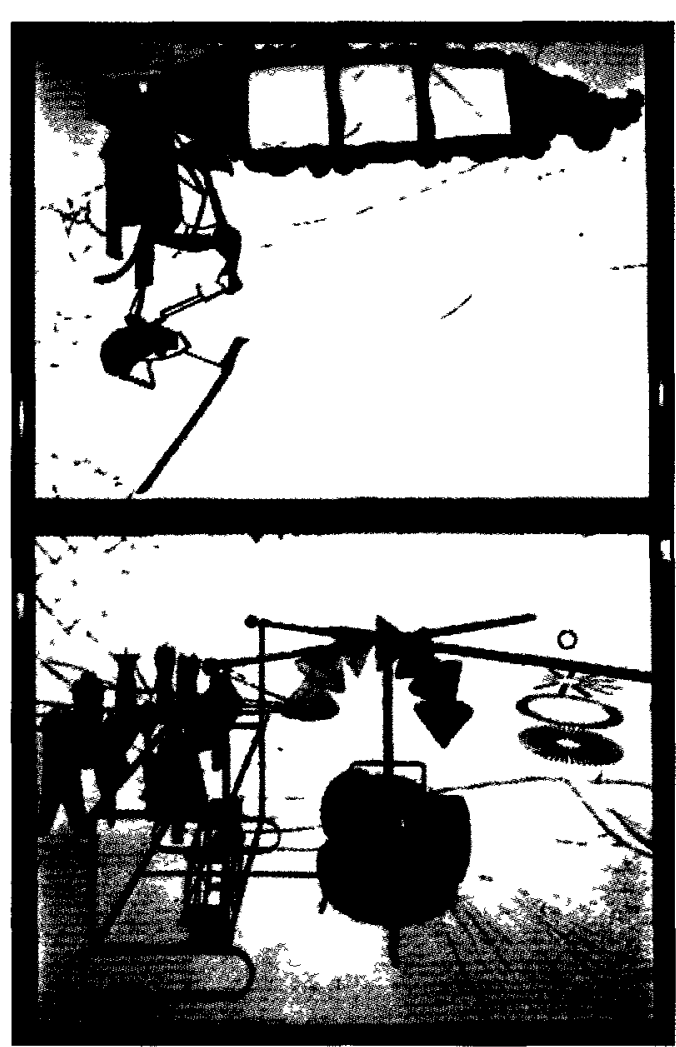

Fig. 3: The Large Glass.
In Marcel Duchamp's sculptures, we see the physical manifestation of deliberately disrupted fulfillment, particularly in his works The Bride Stripped Bare by her Bachelors, Even (1923), also known as The Large Glass, (Fig. 3.) and Given: 1. The Waterfall, 2. The Illuminating Gas (1966), otherwise called Étant Donnés. Both sculptures illustrate the "relationship between the individual and the unattainable reality." ${ }^{20}$ The underlying concept between both works was the idea of an impossible encounter, similar to the voyeuristic scenario employed in the tale of Lady Godiva. In Piper's idea of marginal utility, disrupting fulfillment and the idea of the "impossible encounter" is important; when desire is satiated, the utility is diminished and the feeling of eroticism or wanting disappears. Fulfillment becomes two pronged - it satisfies the desire while tragically eliminating the erotic.

19 Donald Kuspit, "A Critical History of $20^{\text {th }}$ Century Art," Artnet - The Art World Online, Web. 10 Nov. $2010<\mathrm{http} / /$ www.artnet.com/magazineus/features/kuspit/kuspit3-17-06.asp>.

20 Gloria Moure, Marcel Duchamp: Works, Writings and Interviews, (Barcelona: Ediciones Polígrafa, 2009) 42. 
In his Green Box Notes, Duchamp tells us that the Bachelors from the lower half of The Large Glass, depicting the Bachelor's desire for the Bride, never attain the Bride from the upper half. The lower half of the sculpture is the Bachelors'domain, while the upper half is the Bride's domain. ${ }^{21}$ In diagrammatic form, the lower half shows a chain of events, a series of impulses and occurring responses when the female (Bride) desire stimulates the male (Bachelors) desire. The Malic moulds that form the "Erōs's Matrix"22 represent the Bachelors of the story. In their realm, the Bride releases an illuminating gas to be received by the Bachelors, therefore controlling and initiating the consummation. In response to this illuminating gas, the Bachelors proceed through a series of obstacles, by objects such as chocolate grinders. The Bachelors undergo an amorous pursuit of the Bride. Despite the sequence of erotic interactions in The Large Glass, the Bachelors unfortunately never achieve their romantic goal, resulting in a delay their fulfillment. Intriguingly, the sculpture remains static and there are no explicit movements or animations within The Large Glass itself; the sequences between the panes of glass are left up to the viewer's imagination. The sculpture demonstrates how art can invoke memory and engage "the imagination and the intellect, not just the eyes." ${ }^{23}$ Due to the selective transparency of The Large Glass' selective transparency, the viewer

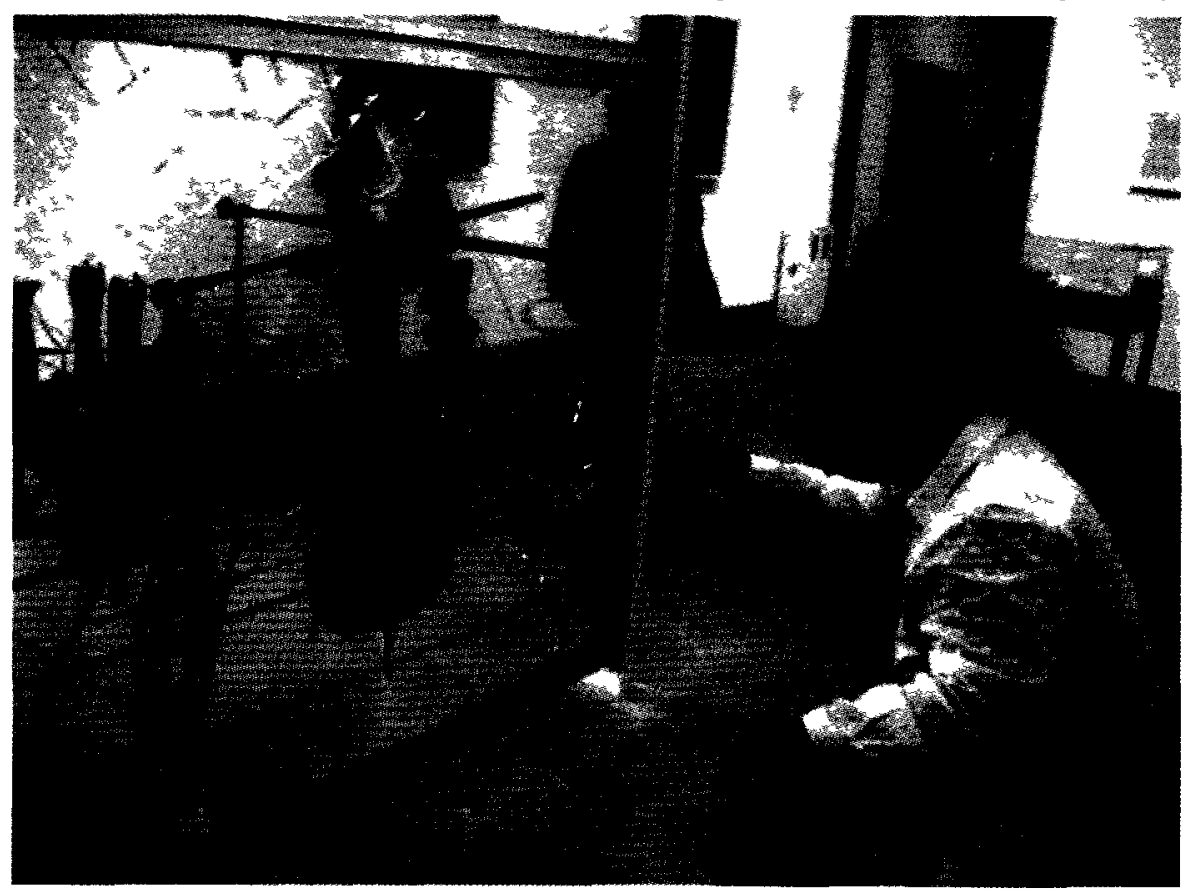

Fig. 6: Lower half of The Large Glass showing the Bachelors' domain.

$21 \quad$ Moure, 84

22 Moure, 75.

23 Andrew Stafford, "Makung Sense of Marcel Duchamp," revised 2008, Web. 7 Jan. 2011 $<$ http://www.understandingduchamp.com>. 
may experience a different interpretation or encounter with the sculpture. It is not surprising then that "the 'erotic' experience sometimes associated with [art and] architecture was often voyeuristic"24 as the interaction with The Large Glass was explicit to the spectator's vision.

One of Marcel Duchamp's objectives in The Large Glass was to "distance himself from everything that had gone before." 25 Thus, Duchamp laid out The Large Glass in an unorthodox format as compared to other diptychs; traditional painting diptychs are organized side by side, but The Large Glass defies convention by composing one-half of the diptych above the other. The panels are constructed out of glass with metal frames. Duchamp chose glass for its intrinsic property of "delay"26 - meaning the glass "shows a sequence of interactions, suspended in time." ${ }^{27}$ Wire, paint, and various other metals compose the imagery between the panes of glass.

The Large Glass is unlike a traditional painting in that, instead of a depicting an illusion of space on a flat, opaque surface, it uses transparency to incorporate the space of the gallery as a place of interaction with the viewer. ${ }^{28}$ The voyeurism is more abstract as The Large Glass is displayed publicly. Viewers attempting to explain the "mystery of the object" can walk around the piece and try to assemble the story of the Bride. Yet they do so in a public setting where anonymity and privacy is not really an issue.

The Philadelphia Museum of Art is home to Duchamp's final work, Given: 1. The Waterfall 2. The Illuminating Gas, otherwise known as Étant Donnés, is a diorama that occupies a room situated at a dead end at the back of the Duchamp Gallery in Philadelphia. The room is locked and cannot be entered. The antique wooden doors for the room are solid, with the exception of two peepholes at their center. The door comes from a Catalan farmhouse, and is framed by bricks made in Cadaqués, ${ }^{29}$ the wooden door appears silver grey from weathering. It is studded with iron rivets but does not have handles or a doorknob - giving the impression that it cannot be opened or entered.

$24 \quad$ Alberto Perez-Gomez, Built Upon Love: Architectural Longing after Ethics and Aesthetics, 61.

25 Moure, 73.

26 Moure, 73.

27 Stafford.

28 Kuspit.

29 Moure, 106. 
In Etant Donnés, the installation celebrates the inclusion of the spectator. It acts as an inverted pinhole camera in which the viewer's mind turns into the projecting screen. The creativity in both works is the ability to seduce viewers and engage their emotions and intellect to recreate the missing context in both pieces. Whereas Étant Donnés appeared realistic in its representation, Duchamp purposely achieved a high degree of abstraction with The Large Glass. He understood that eroticism could excite the imagination without explicitly showing anything. The resulting ambiguity allows viewers to develop a unique interpretation of the sculpture because of the elimination of specific symbolic references.

Only one person at any given time may look through the door (Fig. 7.) at the room inside. What the spectator sees is a brick wall with a shattered opening, showing a life size female model, naked, lying on a bed of twigs and branches (Fig. 8.). The woman's legs are spread open and extend towards the door to reveal her genitalia, and her hair, as well as the bricks from the foreground, which obscure her face and identity. Her right hand is out of the range of vision, but her left arm is raised to reveal that she is holding a vertical glass fixture of a small gas lamp that illuminates faintly. The background is composed of a richly painted landscape that consists of a hilly, wooded landscape and a waterfall. The sky is blue and contains soft, white clouds while the thick woods enclose the pool of water beneath the waterfall. ${ }^{30}$

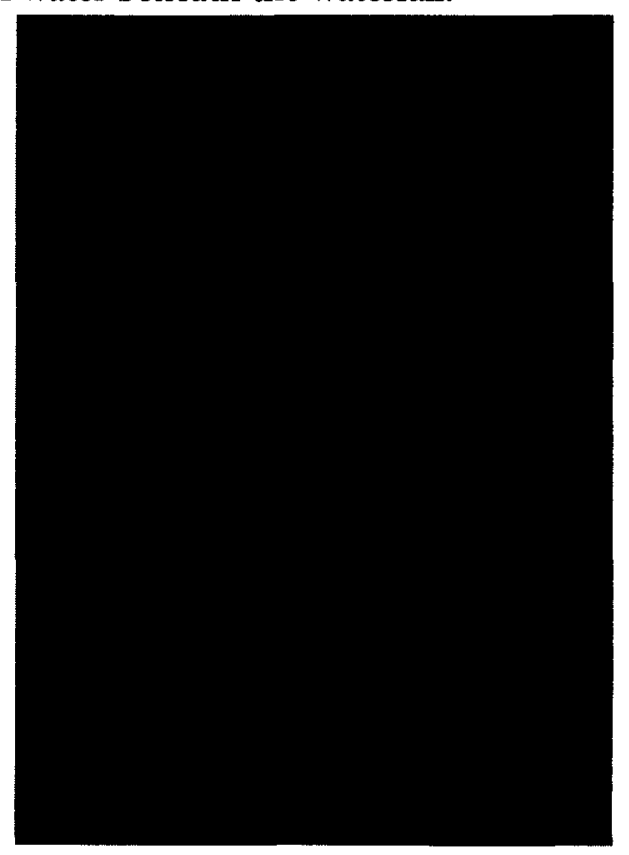

Fig. 7: Étant Donnés - Exterior.

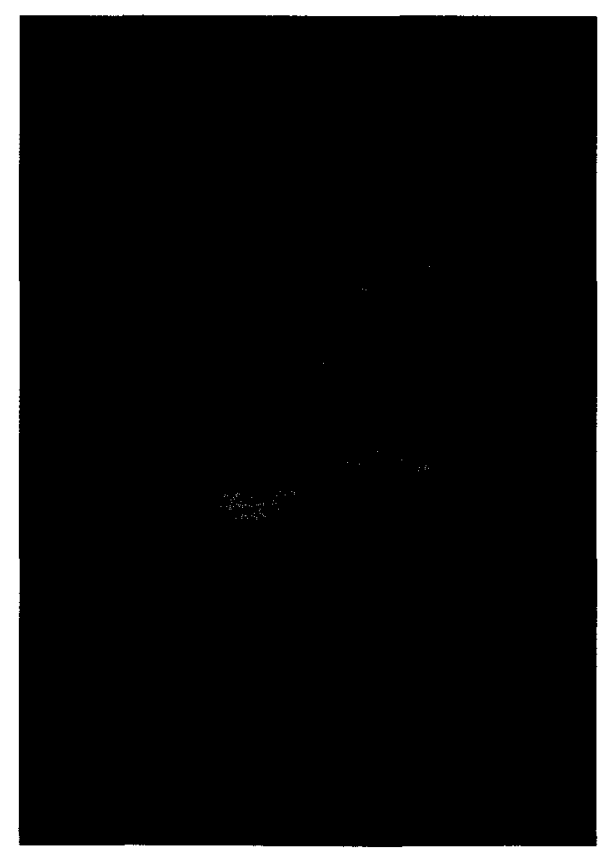

Fig. 8: Étant Donnés - Interior.

30 Moure, 106. 
Duchamp constructed the diorama in such a way that the spectator (should he or she choose to look at the peepholes, as there are no visual clues that lead to it) receives a shocking experience at the scene with which they are presented. The lack of context in the shocking scene is no accident, as Duchamp is attempting to once again engage the participant's imagination. The spectator may imagine it as an aftermath of murder, mutilation, or rape, as the scene exudes an underlying dark and erotic tone with it. In a conversation with British artist Richard Hamilton and art historian Charles Mitchell in 1959, Marcel Duchamp confessed, "Eroticism is a subject very dear to me... in fact I thought the only excuse for doing anything is to introduce eroticism into life." ${ }^{11}$

When the viewer chooses to look away from the door, they have but two options. One is to look into the door a second time or they can step away from the installation and return to browsing the rest of the museum. In Étant Donnés, Duchamp incorporated the surrounding architecture in order to emphasize the eroticism that is present in the voyeuristic act of viewing the piece. It is impossible to see or "look- around" beyond what is given in the frame. Nothing more is known about the situation of the naked woman lying on the bed of branches. The feeling of unease overcomes the voyeur upon the realization that they are looking at a scene they should not be looking at. The intimacy between the voyeur and Étant Donnés is a stark contrast with the experience of viewing regular objects in a museum. Duchamp uses participation in art "to engage the spectator and express a delay between appearance and apparition," 32 and to invoke their imagination, which is necessary for the enhancement of eroticism. Duchamp determined how much detail to reveal to the voyeur and in what perspective or angle the piece must be viewed at. He has deliberately constructed Étant Donnés in such a way that the viewer is kept from examining the details of the construction.

The uneasiness that overcomes the voyeur when viewing through the peephole in Etant Donnés is in the privacy of the act. Each voyeur has their own experience of curiosity, of wanting to look in, and then being troubled by the act of looking. The eroticism experienced while looking at Étant Donnés stems from its secretive nature. The experience becomes a mixture of desire (as the spectator wants to look) and shame (as the voyeur-turned-spectator views the unexpected scene).

\footnotetext{
$31 \quad$ Meeka Walsh, "The Gaze and the Guess: Fixing Identity in Étant Donnés," Border Crossings 29, no. 2 (2010):16-17.

32 Perez-Gomez, Built Upon Love: Architectural Longing after Ethics and Aesthetics, 103.
} 
What Étant Donnés does is highlight the idea of voyeurism as a solitary act (Fig. 9.). By revealing only certain components and not giving the full story of the woman, the voyeur who engages with the installation is left to attach their own narrative, fantasy, or identity to the woman.

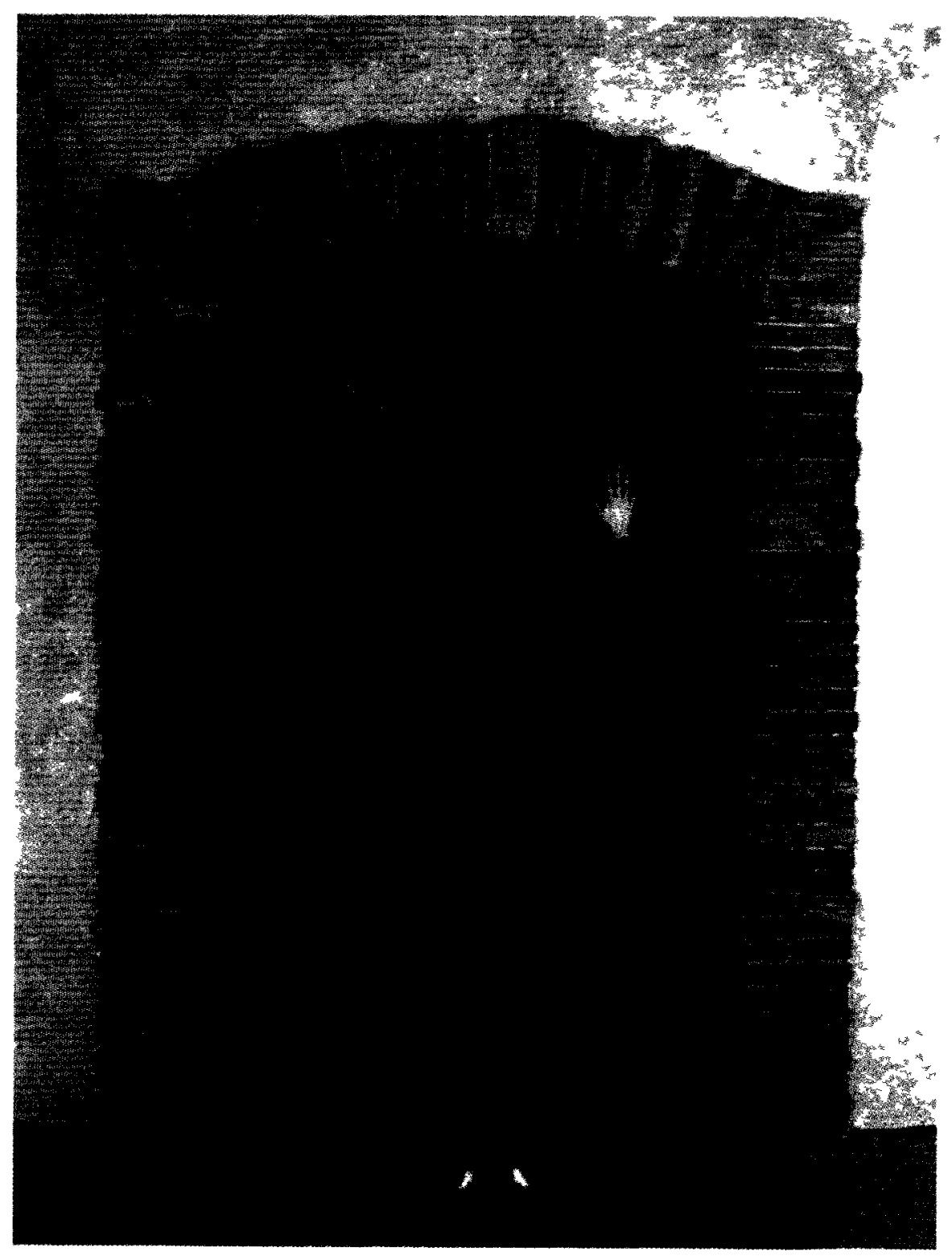

Fig 9. A visitor lookıng into Étant Donnés. 


\section{The Peep Show \\ Portrayal of Voyeurism in Films}

Clay Calvert notes, "cinematic voyeurism is at least twofold."33 First, there may be voyeurism in the content of films, as when one character watches another character or a camera watches a character. Second, there is voyeurism in the relationship between the audience and the film the audience watches the characters on screen, gazing at them without interacting with them or interfering with the action as it unfolds.

The use of voyeurism in the film noir Blue Velvet (1986) is extensive. Different levels of voyeurism exist between characters, as well as between characters and their neighbourhood. The voyeurism in Blue Velvet uses architectural elements in order to articulate and emphasize eroticism. Elements such as screens and framing similar to the conditions that surround Étant Donnés.

In the film, the main character Jeffrey returns home to the small town of Lumberton after finding out that his father experienced a heart attack. While wandering around a farm, he comes across a severed ear, which he turns in to the authorities. The detective in charge tells Jeffrey to leave it to the authorities' hands and that the police will take care of the case, but Jeffrey's curiosity gets the better of him. One night, Jeffrey decides to visit the detective's house to receive more information about the case, and again, the detective tells Jeffrey that he cannot divulge more information. Upon exiting the house, Jeffrey encounters the detective's daughter, Sandy. Sandy realizes that Jeffrey was the one who gave the severed ear to her father and tells Jeffrey that at times, she overhears private matters from her father's study. This time, it is information pertaining to the severed ear. The pair then goes on a walk to discuss the case and ends up on Lincoln Street, where a woman named Dorothy Vallens resides. Sandy had previously overheard that Dorothy is a person of interest in the case.

Jeffrey has a need to satiate his lack of information regarding the case. He conspires with Sandy to somehow gain access to Dorothy's apartment. It is at that moment that Sandy, speaking to Jeffrey, delivers one of the film's more memorable lines: “I don't know if you're a detective or a

$33 \quad$ Calvert, 43. 
pervert." Jeffrey replies: "Well, that's for me to know and you to find out."34

Jeffrey pretends to be a pest control worker in order to deceive Dorothy. Feigning to spray insecticide in her kitchen, Jeffrey spots an extra set of keys to the apartment. A knock at the door distracts Dorothy, giving Jeffrey a chance to grab the set of keys.

A few days later, Jeffrey and Sandy attend the venue The Slow Club - the place where Dorothy works as a nightclub singer. Knowing that Dorothy is preoccupied, Jeffrey and Sandy decide to return to Dorothy's apartment in order to sneak in and find more information about her. Sandy stays as a lookout outside the apartment to warn Jeffrey of Dorothy's return while Jeffrey snoops around inside for any information regarding the case. As he is inside the washroom, he does not hear Sandy's warning honks. Upon exiting the washroom, he hears Dorothy opening the apartment door and, desperate, Jeffrey quickly hides inside a closet. The closet doors are made out of wooden slats. As soon as she enters the foyer, Dorothy starts undressing while Jeffrey peers through the narrow slats of the closet; curious, he observes Dorothy slowly undress herself (Fig. 10.).

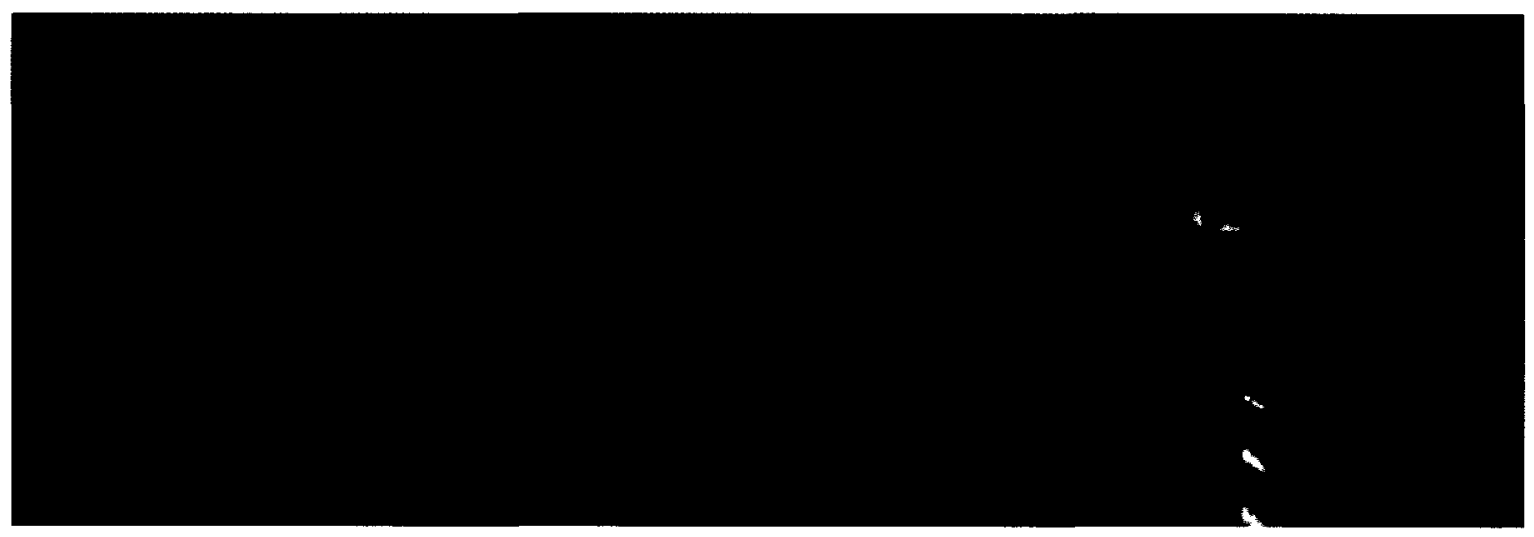

Fig. 10: Jeffrey looking through the closet doors.

Dorothy is alarmed when she hears a rustling in the closet, and retreats to the kitchen to grab a knife. Dorothy proceeds towards the closet slowly and surprises Jeffrey. She threatens to kill Jeffrey unless he himself starts undressing. Dorothy gradually goes on her knees and starts fellating Jeffrey, all the while warning him not to look at her. There is a sudden knock at the apartment door that disturbs their passionate moment.

34 Blue Velvet. Dir David Lynch. Perf. Kyle MacLachlan. De Laurentiis Entertainment Group (DEG), 1986. 
Dorothy, clearly frightened, whispers to Jeffrey to hide in the closet once again. She turns around and when she opens the door, Frank, a burly man, barges in. He is seemingly drunk and psychotic. The moment he enters, he yells at and demoralizes Dorothy, then forces her to participate in a bizarre sexual activity. His sexual arousal is fuelled by sadomasochism and an unknown gas that he inhales intermittently. Frank asks to see Dorothy's genitals before proceeding to hit her every time she looks at him, and then satiates his sexual desire by dry humping Dorothy to the point of climax (Fig. 11.). Frank leaves the apartment shortly afterwards. Behind the slits of the closet doors, Jeffrey has witnessed the entire bizarre event.

Dorothy tries to regain composure and lets Jeffrey out. In her moment of vulnerability, Dorothy wishes for her missing husband and tries to fill the void by longing for Jeffrey's touch. She wants to be satisfied by Jeffrey, and repeatedly asks him to hit her. Jeffrey refuses. With her requests turned down, Dorothy loses interest in being satisfied.

The scene is of importance for the movie as it sets a dark, erotic tone in the characters' seemingly small and innocent town. Voyeurism becomes a strong recurring theme in the movie.

Jeffrey's curiosity leads him into a situation where he chooses to be a spectator, and inside the closet, he unwittingly becomes a voyeur as Dorothy undresses, unaware of his presence. His vantage point is quite important as well, as it lets him see through multiple spaces due to the spatial layout of the apartment. In the movie, Jeffrey proclaims, "he is seeing something that is always hidden."35

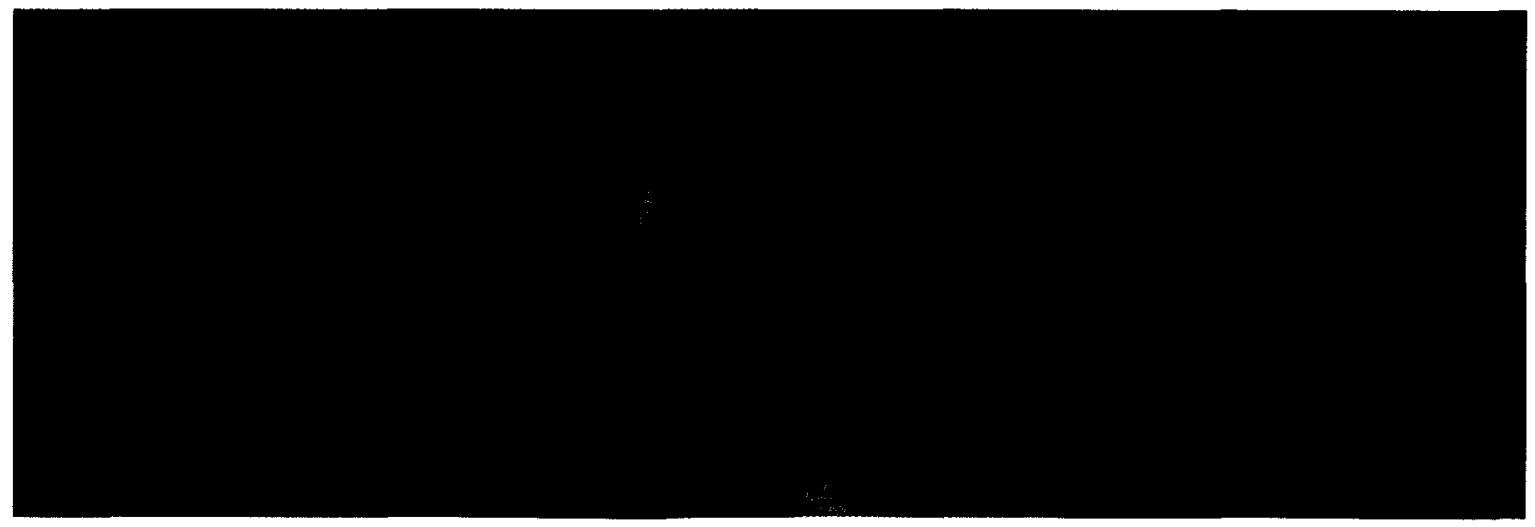

Fig. 11: Frank on top of Dorothy.

$35 \quad$ Blue Velvet. 
The voyeurism in Blue Velvet is not limited to just the closet scene, however. As Jeffrey develops a sexual relationship with Dorothy, he acquires context about the circumstances Dorothy and Frank are in. His curiosity again leads him to want to help Dorothy who was, until recently, just a stranger. This desire to help a stranger unknowingly leads him into the seedy underworld of crime where Jeffrey becomes a voyeur of the dark and hidden underside of Lumberton. Before meeting Dorothy, the Lumberton that Jeffrey knew was just a quaint and quiet town where everyone minded their own business. Now, Jeffrey can have a firsthand look, as he takes voyeuristic approach to Lumberton's darker side.

Jeffrey's engagement and participation stems from wanting to see what is hidden. Again, the lack of context seduces the protagonist to actively participate and engage in Dorothy's situation, as Jeffrey finds her world to be an exciting, dangerous realm he can escape to from his routine life in Lumberton. Dorothy's apartment in Blue Velvet is considered ordinary in terms of spatial regularity, but under the circumstances involving the characters, the spaces became sensual and erotic. Characters began to cross personal and spatial boundaries so much that ambiguity arises between public and private spaces. Blue Velvet is "about Jeffrey's voyeuristic and intimate introduction into a dark, erotically charged adult universe, which he is both hungry to experience and frightened of."36 According to the film critic Roger Ebert, "a film noir is not usually a gangster or crime film, but the story of how evil enters everyday lives... it does not show bad people doing bad things, but average people doing bad things." ${ }^{37}$

In Blue Velvet, David Lynch displays two kinds of scenes: one that portrays the everyday or small-town scenario "in which people go out on dates to the soda fountain and drive around town in shiny cars" 38 and one that portrays a "subterranean scene in which the most unspeakable acts take place behind closed doors." 39

36 Leonard Quart. “20 years later, Blue Velvet is surreal as ever”. Downtown Express. 10 Mar. 2006. Web. 11 June 2011. <http://www.downtownexpress.com/de_148/20yearslaterblue.html>.

37 Roger Ebert. "My Problem with 'Blue Velvet" Rogerebert.com. Web. 11 June 2011. $<$ http://rogerebert.suntimes.com/apps/pbcs.dll/article?AID=/19861002/PEOPLE/41216001>.

38 Ebert.

39 Ebert. 
The "closed door" scenario was used to great effect by one modern architect, Adolf Loos, to blur the preconceived notions of public and private spaces. By obscuring notions of boundaries, his Baker House (1928) and Moller House (1928) created conditions of voyeurism similar to the apartment portrayed in Blue Velvet. People's notions of privacy are shifting due to the desire to watch others and conversely, so are the willingness of others to be watched. As people desire to reveal more about their lives and give permission to be watched by others, their sense of individualism or moral worth may be in a state of decline. 


\section{The Blosed Burtain \\ Voyeuristic Spaces in Architecture}

Adolf Loos was a modern architect well known for his manifesto, Ornament and Crime (1908). His views on aesthetic purity influenced several of his projects to focus on the sensuality of space. Let us take, for example, his Moller House; in it, "there is a raised sitting area off the living room with a sofa set against the window. Although one cannot see out the window, its presence is strongly felt." ${ }^{40}$ Beatriz Colomina states, that "a sense of security is produced by the position of the couch, the placement of its occupants, against the light." ${ }^{m 1}$ The sense of security exists because the person sitting on the couch can detect any intrusion. Conversely, anyone descending the stairs will need a moment or two to realize that there is a presence on the couch. In another section of the house, the sitting area provides a vantage point for whoever overlooks the interior. Ordinarily, intimacy and control is crucial and must be present for the comfort of the occupant. Considered the most intimate space of the Moller House, the sitting area is placed at the periphery of the house, which in turn, pushes a volume onto a street facade, right above the front entrance (Fig. 12.). This creates a paradox regarding the privacy of the house.

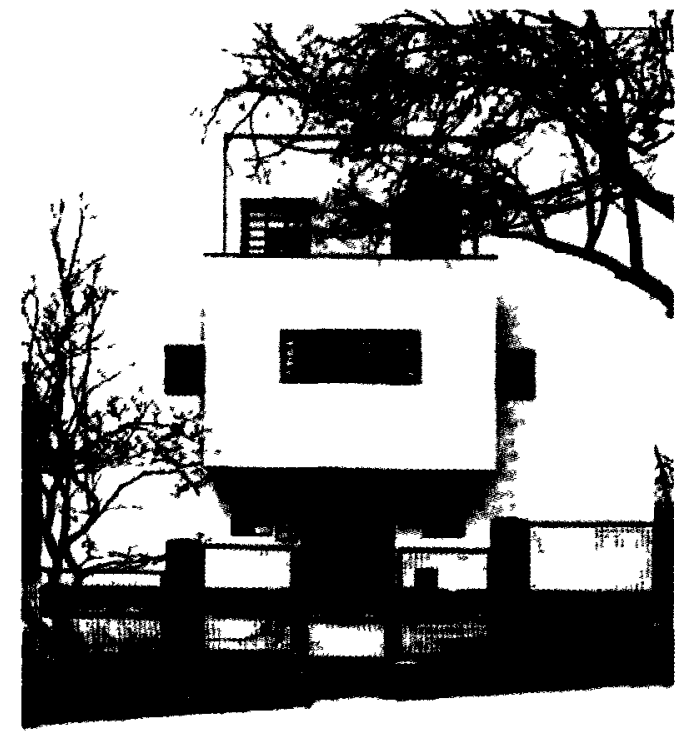

Fig. 12: Moller House - Elevation.

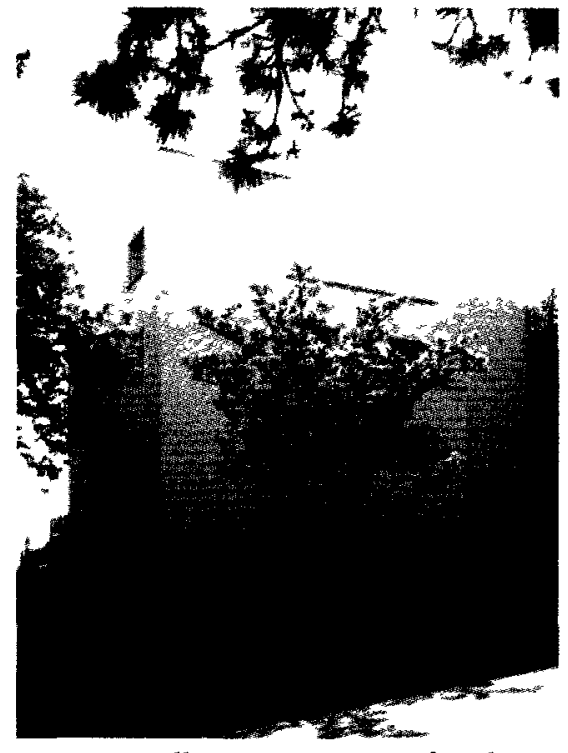

Fig. 13: Moller House - Street façade.

40 Beatriz Colomina, “The Split Wall: Domestic Voyeurism," in Sexuality \& Space, ed. Beatriz Colomina (New York: Princeton Architectural, 1992), 76.

41 Colomina, 76. 
The convention is to place the private spaces away from the public's view, but by placing the house's most intimate space adjacent to the street, it creates another condition for voyeurism and an uneasy atmosphere between both the occupants inside the house and the unsuspecting public. As Colomina observes in her study of Loos: "Architecture is not simply a platform that accommodates the viewing subject. It is a viewing mechanism that produces the subject. It precedes and frames its occupant." 42 In discussing the Moller House, Colomina recalls Jacques Lacan:

I can feel myself under the gaze of someone whose eyes I do not even see, not even discern. All that is necessary is for something to signify to me that there may be others there. The window if it gets a bit dark and if I have reasons for thinking that there is someone behind it, is straightaway a gaze. From the moment this gaze exists, I am already something other, in that I feel myself becoming an object for the gaze of others. But in this position, which is a reciprocal one, others also know that I am an object who knows himself to be seen. ${ }^{43}$

To a voyeur, one reason for the act of looking is to empathize, to share in the experience of the act. Properly designed, architectural spaces become the synergist for participation and social engagement through voyeurism. Unlike Étant Donnés, however, voyeurism in architectural spaces is not limited to a single view. At any moment, the roles may switch and the voyeur may unknowingly become the object of looking.

In one of Adolf Loos' projects, the Baker House, the roles of the inhabitant and guest are reversed. The actress Josephine Baker is now the primary viewing object and the visitors have turned into the looking subjects. ${ }^{44}$ The swimming pool, located at the centre of the house, is deemed the most intimate space: it is a paradigm of sensuality. ${ }^{45}$

\footnotetext{
$42 \quad$ Colomina, 83.

43 Colomina, 83.

44 Colomina, 88.

45 Colomina, 88.
} 
A close collaborator with Adolf Loos on the project, Kurt Ungers, described the project as such:

"The reception rooms on the first floor arranged round the pool - a large salon with an extensive top-lit vestibule, a small lounge and the circular café indicate that this was intended not for private use but as a miniature entertainment centre. On the first floor, low passages surround the pool. They are lit by the wide windows visible on the outside, and from them, thick, transparent windows are let into the side of the pool, so that it was possible to watch swimming and diving in its crystal-clear water, flooded with light from above: an underwater revue, so to speak." 46

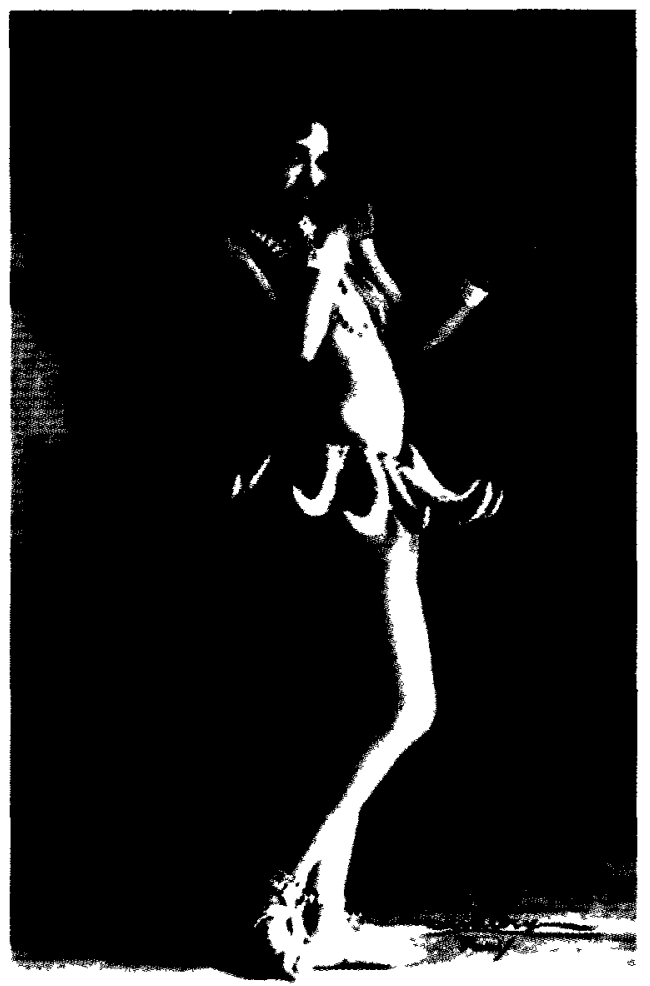

Kurt Ungers implies that the forms of entertainment in the Baker House consist of seeing and being seen. This is natural as Josephine Baker (Fig. 14.) is a singer, dancer, and actress herself; therefore, she is comfortable with the whole notion of entertainment and entertaining. The location of the swimming pool makes it the focus of the visitor's gaze; a skylight illuminates the pool from above, rendering the windows as reflective surfaces that obstruct the swimmer's view, should they choose to gaze at the visitors standing in the spaces above the pool. To make things more complicated, there are moments where the swimmer may see reflections of both themselves and the spectator who is framed by the window. Beatriz Colomina Fig. 14: Josephine Baker. describes this as an "erotic complex of looks" in which the swimmer "sees herself being looked at by another: a narcissistic gaze superimposed on a voyeuristic gaze." ${ }^{47}$ Similarly, Jean-Paul Sartre describes erotic relations as a "system of infinite reflections, a deceiving mirror-game that carries within itself its own frustration." 48

\begin{tabular}{ll}
\hline 46 & Colomina, 88. \\
47 & Colomina, 90. \\
48 & Carson, 11.
\end{tabular}


Farès el-Dahdah, chair of the Graduate Program in Architecture at Rice University, characterizes the Baker House (Fig. 15.) as a "framing apparatus whose function depends on the absence of whomever is to be seen. It is a machine idly waiting for some force to make it work. The body of Josephine Baker is thus strategically framed throughout her own house precisely because she will not be seen... In this house, one can only anticipate the way she might come down the grand stairs or dive into the swimming pool." ${ }^{49}$ The voyeurism inhibited in the Baker house can be attributed to certain details of the house. The framing of views and spaces are important in enhancing the voyeuristic experience. In one example, the stairs of the Baker house are so long that Josephine Baker's approach through them can only be heard at first from the vestibule. Then slowly, her head comes into view, and then the rest of her body follows.

In a similar scenario, there is an area in which the window has been pushed inward and doubled along the façade. This provides an opportunity for someone to look or stare endlessly through the window located on the side of the pool. While he or she is looking, they are also framed by a window located behind them, which "opens onto an aquatic world in which the naked body of Josephine might dive at any moment." ${ }^{50}$ In this scenario, there is an exhibitionist and a voyeur the exhibitionist being the swimmer. The swimmer may not always know someone is watching but there is always the prospect of being observed. Even if the exhibitionist catches on that someone is observing, the identity of the voyeur may still be unknown.

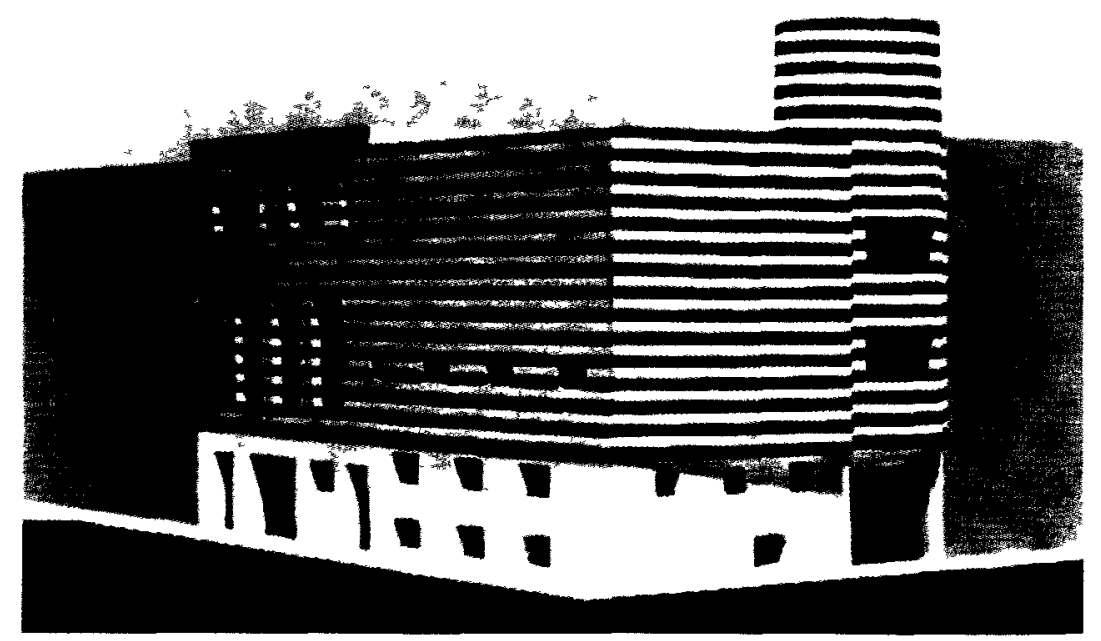

Fig. 15: Josephine Baker House.

$49 \quad$ Fares el-Dahdah, “The Josephine Baker House: For Loos’s Pleasure," Assemblage 26 (1995) 78.

50 el-Dahdah, 79. 
The pool in the Baker House is composed of mirrors that reflect and refract the body of the swimmer. The privacy of the swimmer is entertainment or spectacle for the person in the living room below; the situation serves as an example of how exhibitionists make public their lives for the sake of entertainment. The spectator, or the voyeur, "can now 'dilute' his gaze in the pool's/mirror's fluid tain and thus engage, along with his vision, a haptic sense that makes his eyes, since his hands cannot, caress the absent body of [the swimmer]."51
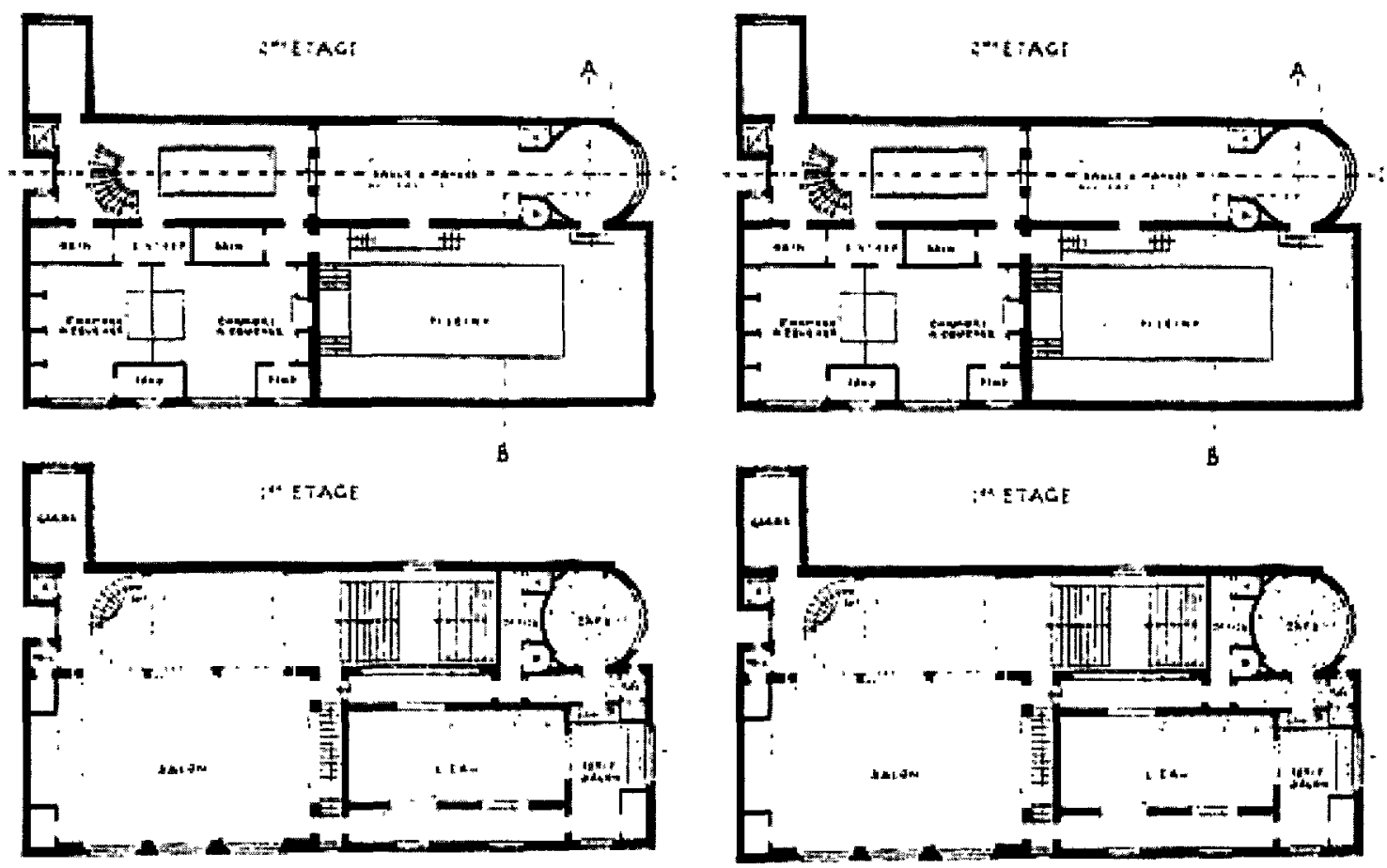

Fig. 16: Josephine Baker House - Plans.

51 el-Dahdah, 80. 


\section{The Badeschiff Voyeurism in a Public Setting}

Translating the ideas of the Baker House's spatial relationship with the pool, which Colomina describes as an "erotic complex of looks" onto a larger scale, results in extensive interest and engagement, particularly in a public setting. One such example is a recent project in Berlin by the firm AMP Arquitectos. In order to encourage a closer connection with the city and the landscape, a Berlin artist - Susanne Lorenz - designed a floating pool (Fig. 17.) to be temporarily placed along a small bend in the river Spree. ${ }^{52}$ In Imperial Rome, public baths existed and were a place for pleasure and encounter. In an interview, Michel Foucault describes the baths as a "sort of cathedral of pleasure at the heart of the city, where people could go as often as they want, where they walked about, picked each other up, met each other, took their pleasure, ate, drank, discussed..."53

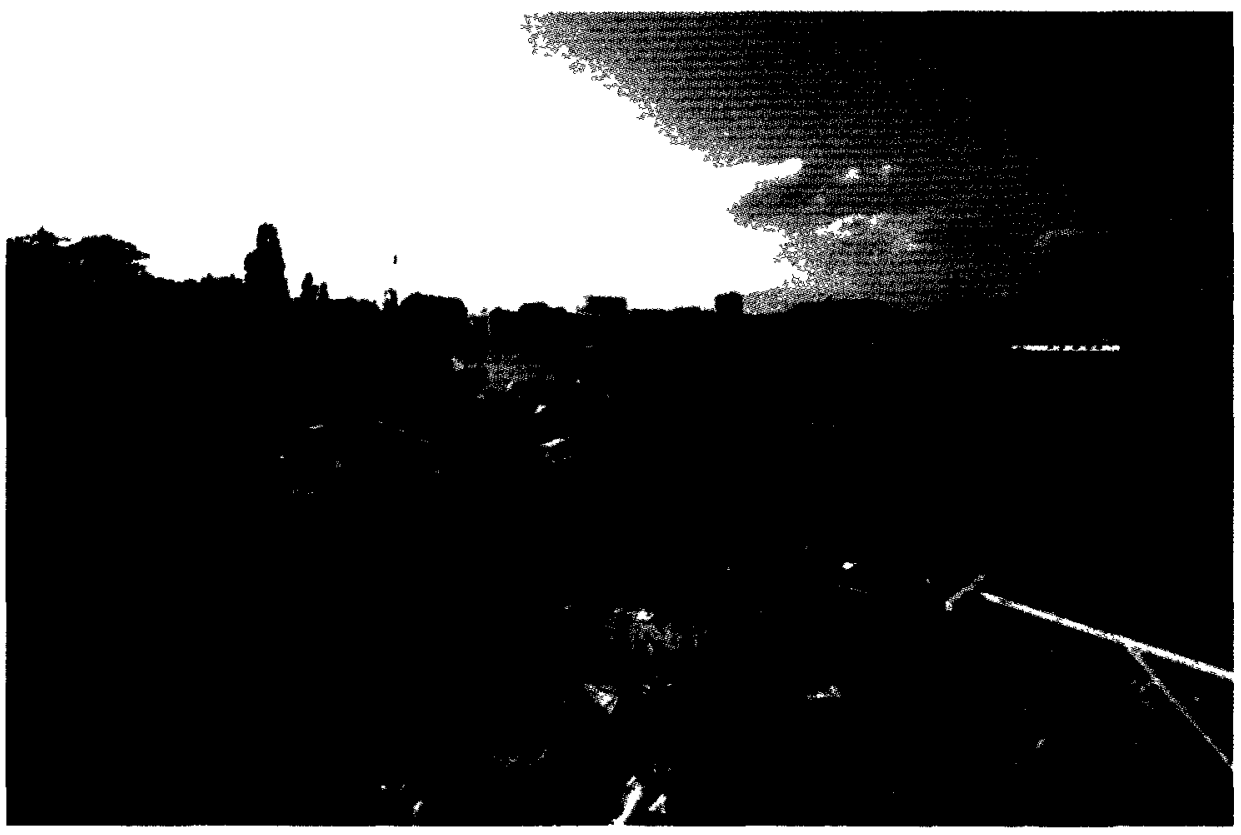

Fig. 17: The Badeschiff during the summer.

The adaptive reuse proposal by Susanne Lorenz does not attempt to be a fully-fledged bath from the ancient times, but it does try to bring the public together through something unconventional, by incorporating eroticism in its strategy. As it is an adaptive reuse project, AMP Arquitectos used

52 AMP Arquitectos. Web. 6 Dec. 2010.<http://www.amparquitectos.com/main.html >.

53 Michel Foucault, "Space, Knowledge, and Power," interview with Paul Rabinow, Skyline, March 1982; rpt. in Architecture Theory Since 1968, ed. K. Michael Hays (Cambridge, MA: MIT, 1998), 436-37. 
an old industrial lighter (barge), semi-submerged it, and filled it with treated water so that the public could use it as a swimming pool - a pool that floats in the river Spree. The firm used a vessel that commonly travelled the Spree, known as a Schubleichter, which was stripped down, and its hull transformed into a superstructure for the base. The hull was then filled with chlorine-treated water in order to submerge it in line with the Spree, which gives it an effect similar to an infinity pool. The Badeschiff (literally bathing ship) was originally planned as a temporary installation for one summer. The pool was well received, and the public's reaction was so positive that the company that owns the Badeschiff decided to make it a permanent pavilion in Berlin. During the winter, the pool platforms evolve into three different spaces: a lounge, a sauna, and the pool. A winter membrane is erected in order to house the new spaces as well as any necessary equipment (Fig. 18.). The two-layer membrane consists of elliptical wooden trusses that are connected by slender steel rods in order to support the skin. The membrane wraps tightly around the trusses to create a rib-like impression.

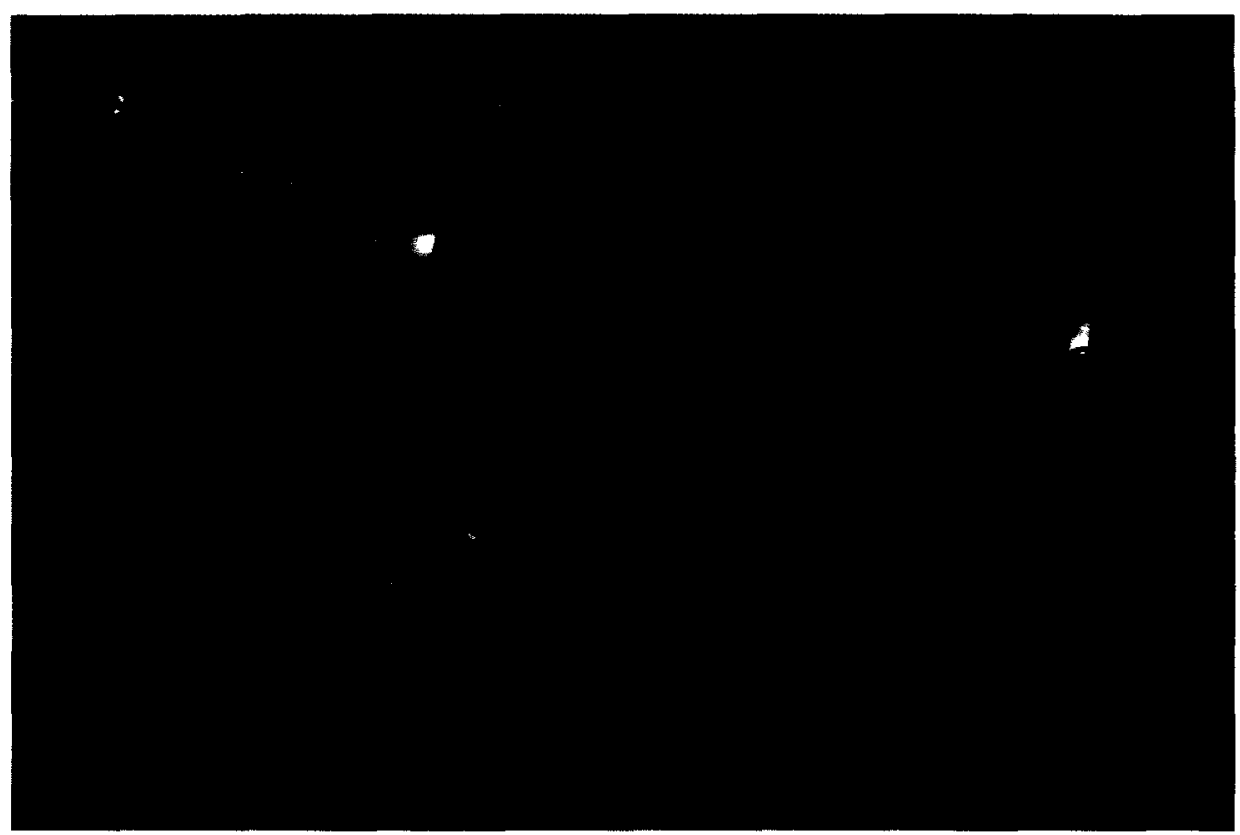

Fig. 18: The Badeschiff during the winter.

Anne Carson calls to attention that "Erōs is an issue of boundaries" and that Erōs exists "in the interval between reach and grasp, between glance and counter-glance." It is at these intervals that the "absent presence of desire comes alive." ${ }^{44}$ Bathing is presently considered a private act. In our homes, the bathrooms tend to be the most private and secluded rooms. The boundary crossed by the Badeschiff is in its placement; similarly to the Baker House where the placement of the pool 54 Carson, 30. 
allowed it to be the focus of the visitor's gaze, the Badeschiff's location in the Spree allows it to be the focus of the public's gaze.

During the summer, the Badeschiff is completely, exposed along with its participants so that the act of bathing takes place in a completely public space. Anyone who walks past this area of the Spree will see the bathers. Conversely, the swimmers and bathers participate knowing that they are exposed and can be watched at any given time. It is the condition, once again, of the voyeur and the act - the glance and counter-glance - a moment where the absent presence of desire comes alive.

In the winter, the Badeschiff completely transforms. The weather makes it too cold for swimmers and bathers to be completely exposed to the elements. Thus, a membrane is erected over the pool and the wooden platforms connected to it. The membrane structure consists of elliptical wooden frames supported by steel rods. Creating the structure proved to be challenging for designers, as there were three requirements to be fulfilled. The Badeschiff's original design did not account for additional weight from a new roof; the new structure had to be flexible and easily dismantled for the summer season, and finally, it had to correspond with the aesthetic vision of the artist and the architects. For the winter, the Badeschiff's programs consist of a lounge, a sauna, and a pool. The closest platform turns into a sauna for people's relaxation, and the swimming pool remains mostly unchanged, with the exception of the additional roof structure.

The assembled winter membrane adds another layer of sensuality to the Badeschiff. Each structural member must be chosen carefully to ensure minimal weight and profile due to the converted barge's space and weight limitations. Interestingly, the membrane does not fully enclose the spaces of the Badeschiff and has an ironic effect, as the membrane intended to cover actually makes the Badeschiff more erotic. The membrane uses selective transparency as a method to conceal certain spaces, but it also creates openings that provide glimpses into the activities within.

The Badeschiff is successful in the sense that it questions the notion of what is considered private space and private activities, by bringing them into public space. The result of the project was a reinvigoration of the community in an otherwise empty stretch of the Spree. 
We recall that in Lady Godiva's tale that Godiva consented to ride out naked because she felt secure to do it. No one was allowed to view her and Godiva believed that no one could. The locked doors, shut windows, and the villagers out of sight gave Godiva the sense of security she needed to perform her task. Similarly, the Badeschiff provides the membrane as a way for the patrons inside to feel secure. The membrane gives protection from the elements and from peering eyes, well, most of the time. The selective transparency provides (Fig. 19.) vantage views for the unsuspecting public to become a voyeur. As in the case of Etant Donnés, the newly turned voyeur can keep engaging in the activity, anonymously, or leave. I say anonymously because the patrons of the Badeschiff also have the (false) sense of security that Godiva had and there is virtually no way for them to know if anyone is peering.

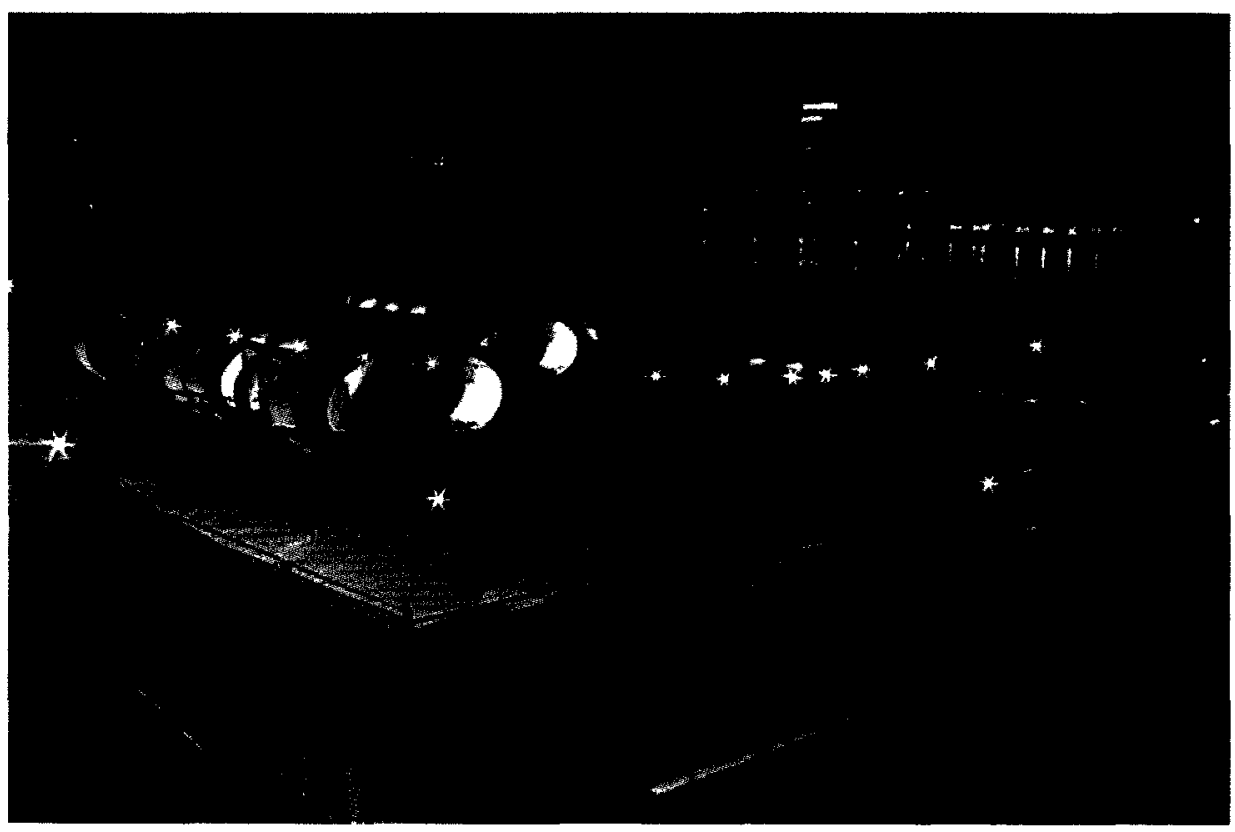

Fig. 19: The Badeschiff showing selective transparency. 


\section{The Exhibitionists}

Using Voyeurism in the Spotlight

In the painting, sculpture, film, and architectural examples discussed, voyeurism co-exists with exhibitionism. The pleasure of the voyeur and the exhibitionist are reciprocal. Again, following Calvert, the exhibitionist is motivated by four factors: self-clarification, social validation, relationship development, and social control..$^{55}$

Self-clarification involves individuals that "think about and focus attention on themselves in preparation of [revealing] themselves to others." ${ }^{~} 6$ Social validation transpires when individuals open up and reveal themselves to others in the hope of obtaining advice and feedback on the "appropriateness or correctness of their beliefs or behaviours." 57 The development of a relationship occurs when disclosure of information happens as a form of interpersonal exchange. Lastly, social control refers to the person who discloses and "engages in impression management by selectively and strategically revealing certain pieces of information to influence the opinions of others. ${ }^{58}$

If we recall Dorothy Kelly's analysis of voyeurs in French novels, she describes the voyeurs as spies who wish to learn about others; the knowledge they gain gives them, in a certain sense, power over the person they spy on. The voyeur does not give information, but rather, he or she is the taker of information and as such, is able to learn about other people's lives just by watching them. The power associated with the voyeur's privileged vantage point may also be rewarding for the voyeur in terms of knowledge. As Calvert explains: "The voyeur knows something important that the individual does not - that the individual is, in fact, being observed."59

The examples of art, film, and architecture discussed in this thesis - The Large Glass, Etant Donnés, Blue Velvet, the Moller House, the Baker House, and the Badeschiff - all fulfill some of the different motivations that drive exhibitionists: self-clarification, social validation, relationship development, and social control. Since voyeurism requires both an exhibitionist and a voyeur, these examples provide a basis for successful voyeuristic scenarios.

55 Calvert, 84.

56 Calvert, 83-84.

57 Calvert, 84.

58 Calvert, 84.

59 Calvert, 69. 
In Étant Donnés, Duchamp revealed only certain elements to the viewers or spectators. He placed the peephole selectively to limit the viewer to only seeing what the artist wanted them to see. Even the construction of the art piece is hidden from the public, to enhance the voyeuristic effect.

Female characters are central to both Blue Velvet and the Baker House. The characters Dorothy and Josephine Baker show evidence of exhibitionists. Dorothy had moments of selfclarification, as she craved attention from others because her husband and her son were not present, and gained that attention by performing in the club before revealing herself to Jeffrey. She needed to be validated by Jeffrey in the emotional sense, and her disclosure of her legal and personal troubles led to the development of a physical relationship with Jeffrey. But Dorothy still had to be careful with what she opened up to him about - that is where her social control set in.

Similarly, Josephine Baker, as an actress, is used to the concept of exhibitionism. In her house, she carefully controls and chooses how much she reveals. The architect, Adolf Loos, controls the exposure of the guests as well, through architectural views and detailing. The way he used mirrors, windows, glass, transparencies, and even reflections of the water all contributed to the exposure or exhibition of the guests in the Baker House.

The Badeschiff, on the other hand, fully reveals the truth of its construction. In the winter, the framing and structural detailing expose the interior to the participants of the Badeschiff. Although the construction is revealed to the participants, that same structure selectively and partially conceals the participants from the outside. Through openings and transparencies, a member of the public becomes a voyeur as he or she chooses to look at the events happening inside the Badeschiff.

Godiva's tale exemplifies moral contrast through "self-display not merely as something shameful and dangerous but also as something positive: her erotic appeal allegorized as public fame." ${ }^{60}$ The public fame refers to the time when women of the middle class in the $19^{\text {th }}$ century prized Godiva's moral tale of willing to "risk public scandal for a higher moral good." 61 Godiva leaves her home to be shamed in public, yet after achieving her goal of improving society, she returns with her virtue is still intact. In a similar vein, we have Loos' architecture designed to breach social privacy constructs for the sake of entertaining inside the Baker House.

60 Donoghue, 92.

61 Donoghue, 92. 
Today, privacy in the home is taken for granted. In the middle ages, privacy was a privilege reserved for a select group. Since Godiva was an aristocrat, her choice to deliberately renounce said privacy was shocking as she was one of the few in her society who could preserve her privacy. Daniel Donoghue expresses, "the legend dramatizes the taboo associated with voyeurism, but it is typically invoked only to be circumvented. It also celebrates Godiva's physical beauty and the pleasures of the gaze, but in ways that strive to maintain social respectability." ${ }^{2}$ Donoghue implies that by attributing a motive that is self-sacrificing to her public exposure, Godiva justifies her scandalous deed. But a deeper analysis of the tale reveals additional issues "such as the relation between the private and the public, guilt and shame, desire, taboo, honour, scapegoating, and the gendering of the gaze." ${ }^{63}$ The "gaze" in Godiva's tale presents itself on a number of levels. As the tale could only be passed on by word of mouth or by written means. A spoken or written version leaves it up to the listener or reader to imagine Godiva's nakedness. Even if the populace in the tale was forbidden to look at her, the listener or reader has the ability to cross that boundary because it occurs in the listener or reader's imagination. The second is within the narrative itself in the personification of the voyeur, Peeping Tom.

The voyeuristic role combines "transgression and wish-fulfillment [that] has found deep resonances in modern Western culture."64 One sees this "transgression and wish-fulfillment" exemplified within the case studies looked at earlier. For instance, Jeffrey shows the relations between honour, taboo and desire by breaching social and legal rules in order to aid Dorothy. Duchamp explicitly plays with the viewer's guilt and shame when looking inside his Étant Donnés. When the Philadelphia Museum of Art first installed Étant Donnés, visitors flocked to the museum and asked, some in a whisper, to see the "peephole picture." After turning away from the peephole, many contained a puzzled look in their face, yet everybody looked shocked. ${ }^{65}$ Although the door physically separates the peeping observer and the reclining girl to create a tense and unbridgeable experience, it is still a space of participation. ${ }^{66}$

\footnotetext{
62 Donoghue, 2.

63 Donoghue, 2.

64 Donoghue, 5.

65 Alice Goldfarb Marquis, Marcel Duchamp, the Bachelor Stripped Bare: a Biography, (Boston: MFA Publications, 2002) 303.

66 Perez-Gomez, 104.
} 
The roles of the voyeur and exhibitionist are tightly intertwined, as they are the subject and the object. In Duchamp's works, the sculptures are the objects and the museum visitors the subjects. In Blue Velvet, there is Jeffrey, Dorothy, and adds another voyeur - the person watching the film. The Moller House has the inhabitants and the public while the Baker House had Josephine Baker and her guests. In the moral tale of Lady Godiva and Peeping Tom, we see the development of "complementary opposites." ${ }^{67}$ The tale portrays Peeping Tom as "hidden while [Godiva] is on public display; his gaze is active and she is its passive object; his social position is low and hers is high; he is wicked and she is virtuous; his sexuality is questioned while hers is affirmed; his conscience feels guilty where she feels shame; he is punished and she is rewarded." ${ }^{8}$ 'The tale also demonstrates power when the Earl, Leforic, "desires to display what he possesses without relinquishing it." 69 Conversely, the voyeur's intrusive gaze is "motivated by a desire to possess what he cannot have."70 One can assume that in Lady Godiva's exposed state, she feels shame and Peeping Tom feels guilt. Throughout the tale, as Donoghue explains, "The guilt of the voyeur is superseded by shame, which prompts the subsequent realization of oneself as an object in the eyes of another, even when there is no 'other' there, when the alarm is false. A gazer-at-the-keyhole who is indifferent to the shame of being caught in the act would presumably no longer be a voyeur, and indifference could come about only when guilt is absent." ${ }^{11}$

Colomina states that architecture is not just a "platform that accommodates the viewing subject. [Architecture] is a viewing mechanism that produces the subject." ${ }^{2}$ In Loos' architecture, he uses mirrors to "promote the interplay between reality and illusion" 73 as a means to convolute or blur the notions of boundaries between inside and outside. As well, the ambiguity is amplified by Loos' strategy of separating sight from the other senses. Physical and visual connections are not readily apparent in Loos' houses due to the separation. Unlike Étant Donnés, which has a physical barrier, the Moller House subtly uses framing for openings to enhance the stagelike effect. For instance, the music room is 70 centimetres below the dining room and the only means of access

67 Donoghue, 69.

68 Donoghue, 69.

69 Donoghue, 62.

70 Donoghue, 71.

71 Donoghue, 79.

72 Colomina, 83.

73 Colomina, 86. 
is to unfold hidden steps in the timber base of the dining room. Loos repeats this framing strategy in his interiors; interestingly, what Loos' frames is "the traditional scene of everyday domestic life."74

A further example of a voyeuristic scenario involving everyday life will be explored in the next chapter. Framing was an important issue in the design and subsequent renovations and additions.

$74 \quad$ Colomina, 86. 


\section{The Seduction \\ Voyeuristic Documentation}

The Directed Research Studio began with the documentation of an urban site in Ottawa that included the First Baptist Church-a designated heritage building. The site was part of a block on Elgin Street, between Laurier Street and Gloucester Street (Fig. 20.). The documentation process involved using a Leica Scan Station 2 to record point-cloud data of the site, including the First Baptist Church. Our group stationed the 3D scanner in multiple locations over the course of two weeks to gather the point-cloud data. Half of the area of the chosen site was dedicated to a parking lot, and this is where our group took most of the 3D scans. We experienced the voyeuristic aspects of the project in two distinct ways, as both the subject and the observer. As we were out in the open, any number of people could have been watching us from the multitude of office and apartment buildings surrounding the parking lot. Some parallels could be drawn to the Panopticon, in which the 3D scanner would be the "guard" and its task to record information in its line of vision. In that same vein, the members of our group were the voyeurs of this heritage-designated church.

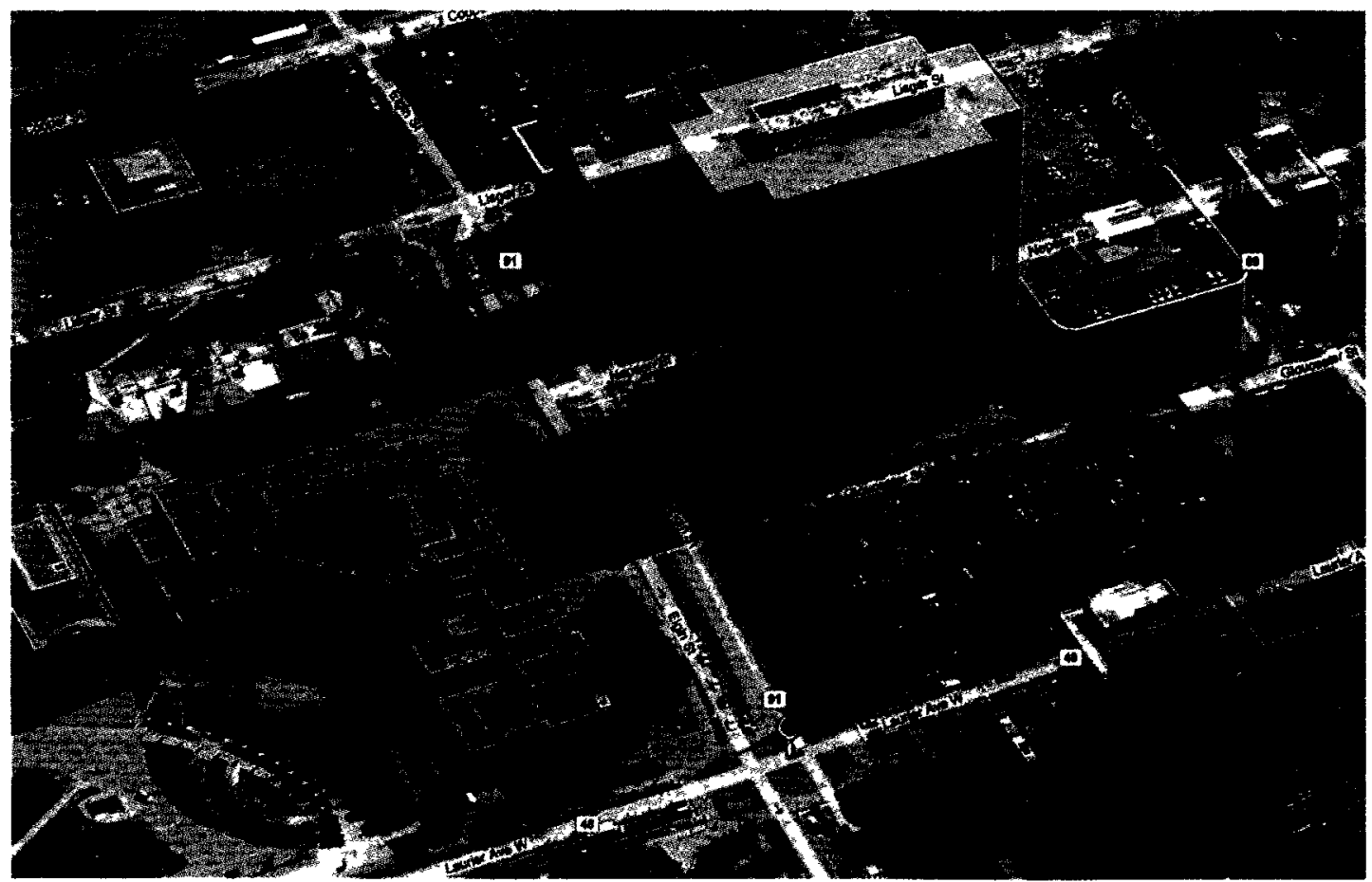

Fig. 20: Aerial view of Elgin and Laurier, Ottawa. 
The construction of the church began in 1877 and Prime Minister Alexander Mackenzie laid the first stone. James Mather, the architect of the church, designed it in a Gothic Revival Style. In its time, the First Baptist Church had quite the street presence, as nearby buildings consisted of low-rise housing apartments. The architect planned the interior in an amphitheatre style so that the pews faced the west wall, because this is where the baptistery was located, and as a result, it became the focus of the congregation.

In 1914 , the construction of a new addition, or Annex, was approved. The addition allowed for the expansion of educational facilities, the rebuilding of the organ, and the relocation of the choir behind the pit. In order to connect the Annex to the original church, significant structural work was needed, namely opening a large two-storey arch in the masonry of the west wall. Unfortunately, in 1928 , the interior west wall sustained damage due to a roof leak. The damage was serious enough to loosen a portion of the plaster wall near the pulpit platform. The renovations afterwards dramatically changed the interior, as the architect at that time, A.J. Hazelgrove, recommended that the sanctuary be converted to a nave and chancel from an amphitheatre plan. The new rectangular layout featured a rectangular nave, with a centre and side aisles. The pews were positioned row on row facing the south wall, where a stepped chancel, a pulpit, and a lectern are situated. The congregation held its first service after the renovations on the Church's $50^{\text {th }}$ anniversary. The last major change was in 1966, when the acquisition of newly acquired Casavant Fréres organ required structural changes to the gallery. In order to have enough space for the organ and the organist, the church needed to extend the depth of the gallery for a proper cantilever.

Presently, the church does not have the same imposing presence as it did in the early 1900 's. Multiple buildings, physically bigger than the church, have popped up. From the street, one notices that the First Baptist Church's main entrance features wooden doors. Once well kept and pristine, the doors currently appear dull, faded, and show signs of wear and tear. On the north side of the sanctuary is the cantilevered organ gallery. Situated above the organ gallery is another set of stained glass windows that adorn the face of the north wall. The stained glass windows are much larger than the stained glass windows located on the east wall. They were designed by the artist Peter Howarth and are collectively called the Memorial Window. Three figures make up the composition of the memorial window; Christ the Carpenter in the centre, a lumberman to 


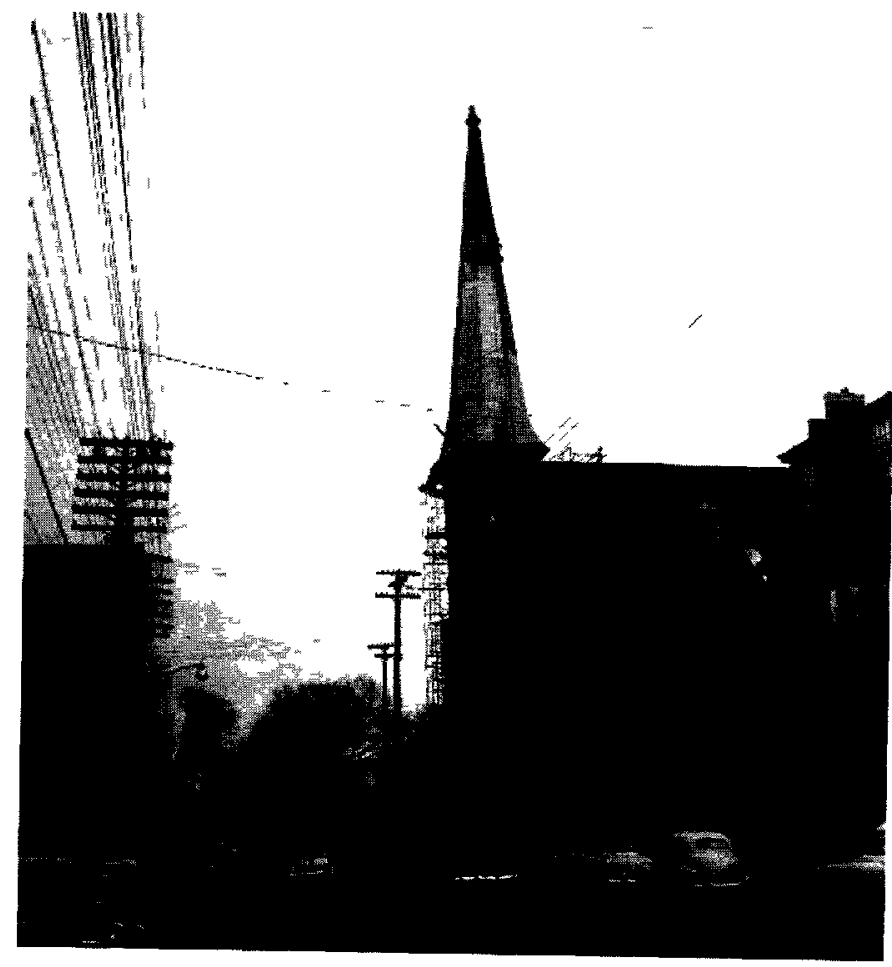

Fig. 21: First Baptist Church.

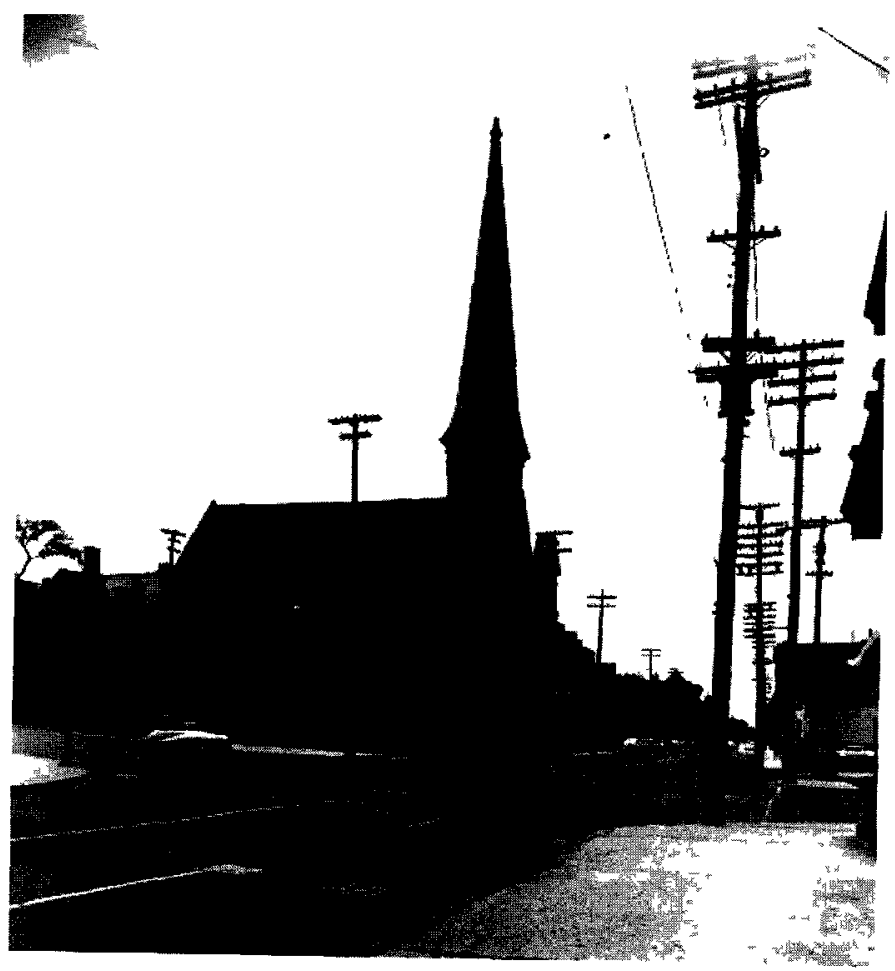

Fig. 22: First Baptist Church - West façade. 
his left, and a river man to the right. The overall theme is that of man and nature. The lumberman symbolizes the dignity of labour, while the river man symbolizes creation. Other objects within the Memorial Window include the Tree of Life, the Vine, the Cross, and the Dove. The bottom part of the composition depicts Canadian trees during the spring, winter, and autumn seasons.

Above the sanctuary is the exquisitely crafted wood ceiling, made with a hardwood and possibly stained in order to radiate a reddish-brown colour. The wooden ceiling is composed of grids with diagonal slats filling each grid. One cannot tell from the condition on the outside, but the interior is in fairly good shape.

Outside the First Baptist Church though, is a different atmosphere. Whereas in the early 1900 's the Church's congregation totalled upwards of 550 people, nowadays, the active congregation is around 70 people. Similarly, the First Baptist Church's street presence has faltered; the times are long gone when the Church and its steeple were the dominant sight around the neighbourhood. Today, it is overshadowed by significant buildings, such as the Bell Tower to its south and the city hall and government courthouses to the east. An empty parking lot dominates the block that the church is situated in. Adjacent to the church are a few more offices, along with a now abandoned residence that is, roughly, a contemporary of the church.

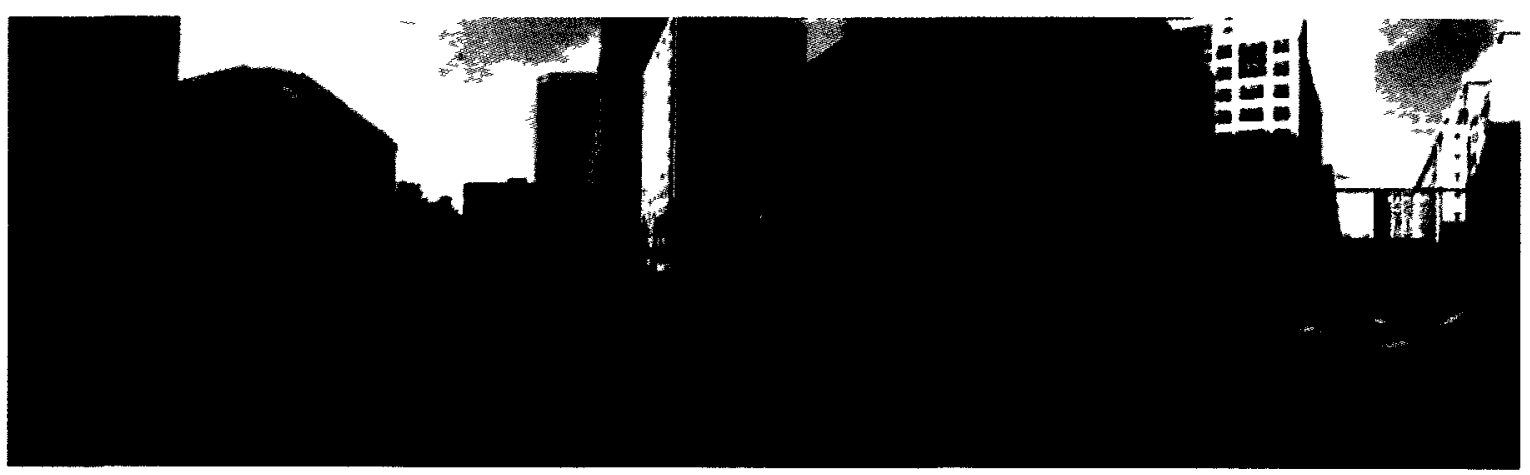

Fig. 23: North parkung lot - daytıme.

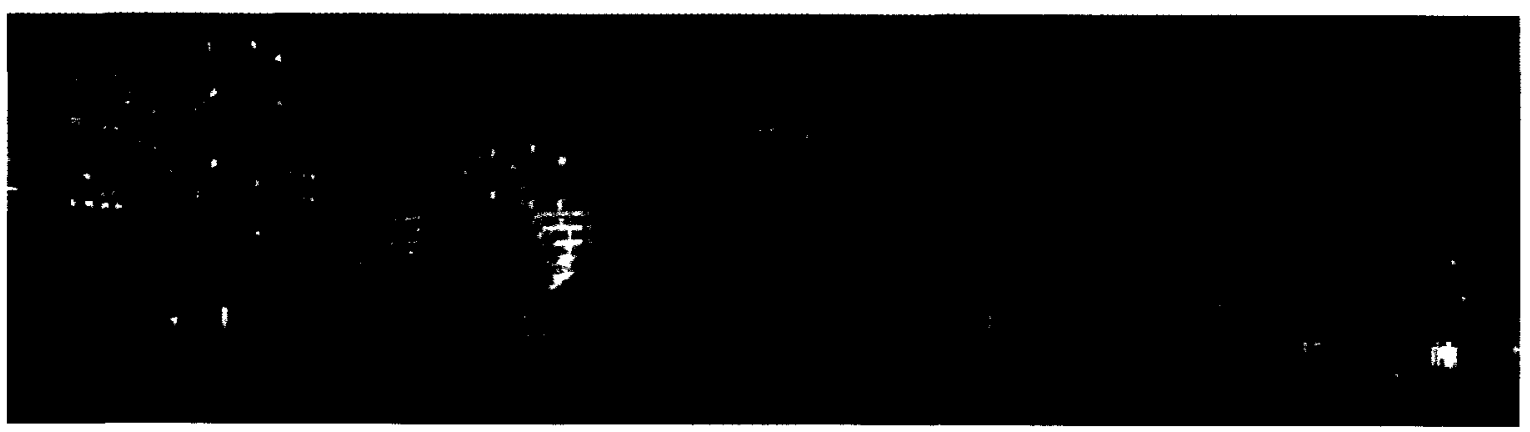

Fig. 24: North parkung lot - evenıng. 


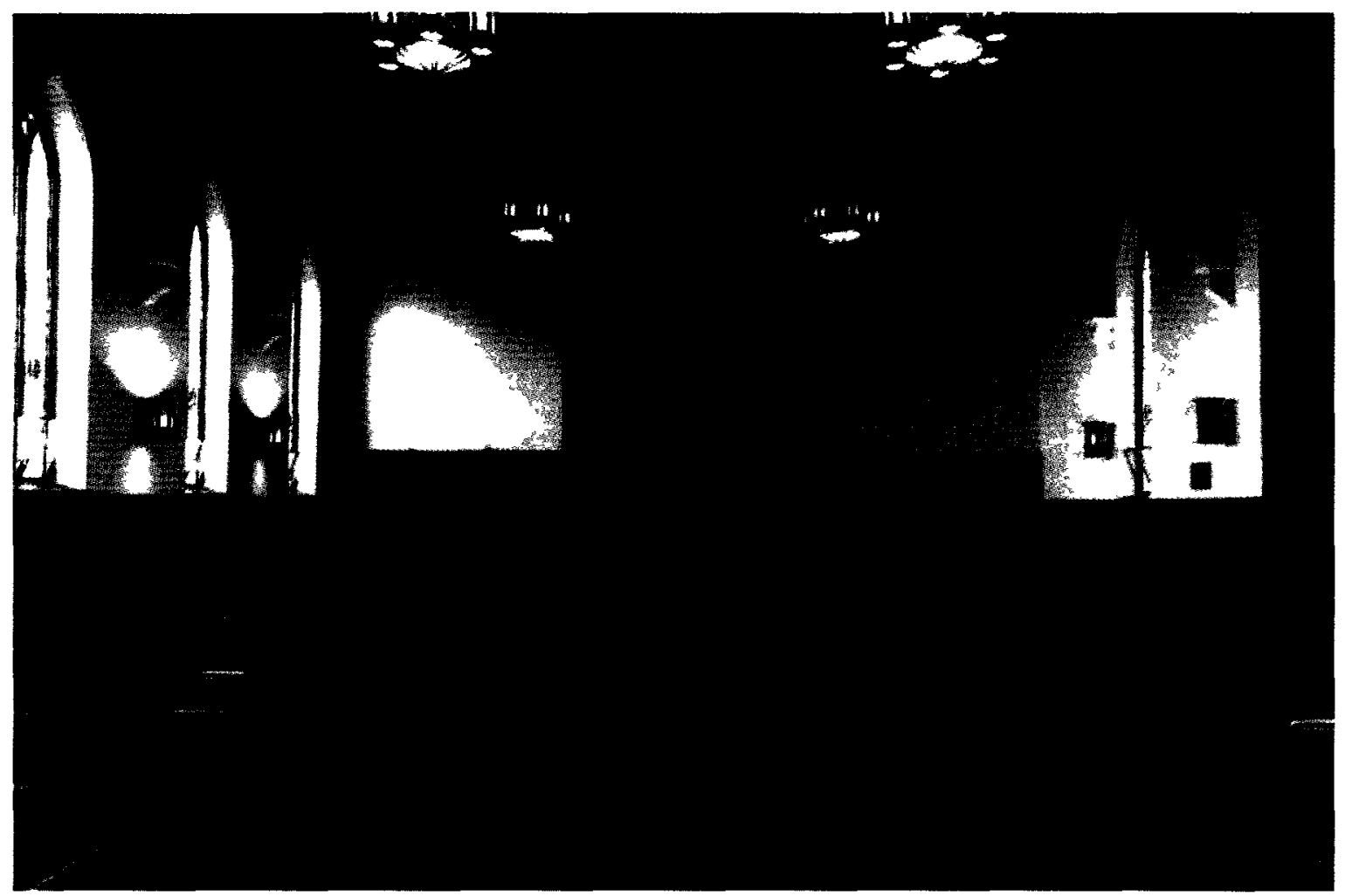

Fig. 25: First Baptist Church - Interior, sanctuary.

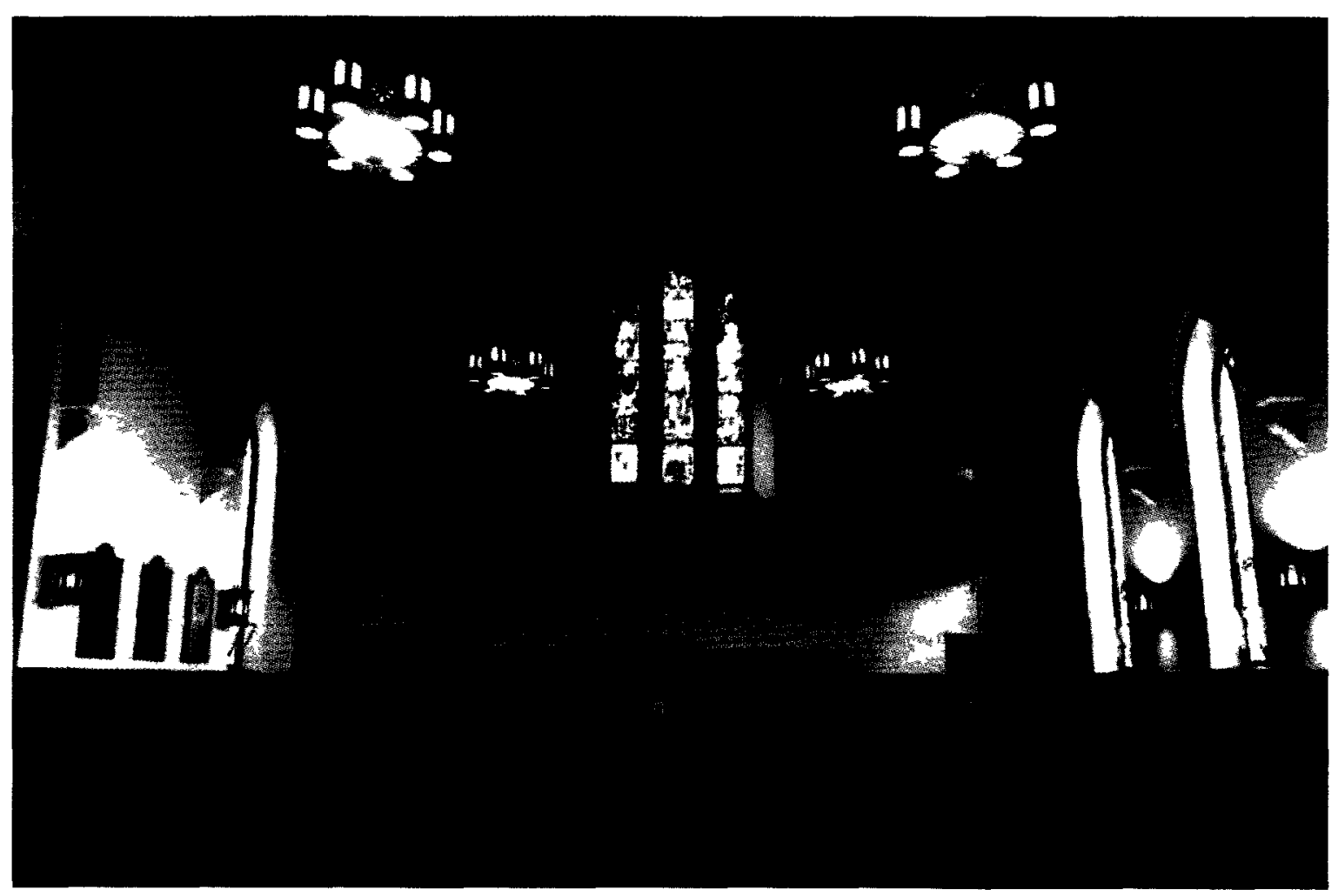

Fig. 26: First Baptist Church - Interıor, organ gallery. 


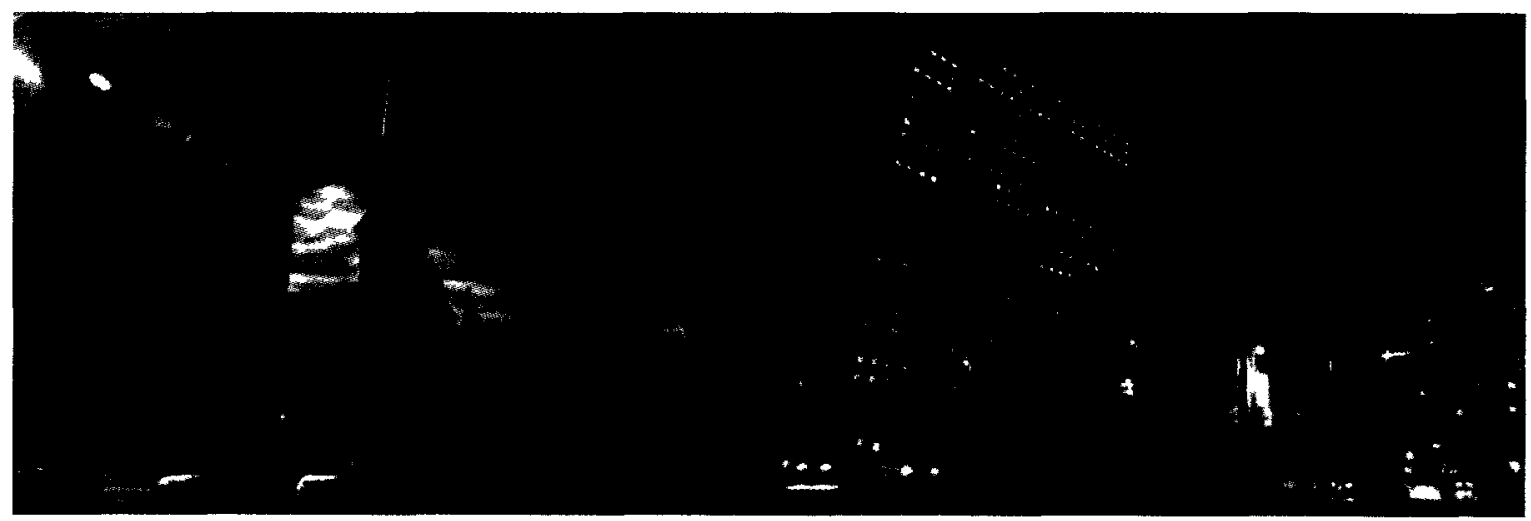

Fig. 27: Day and night conditions from Elgin Street.

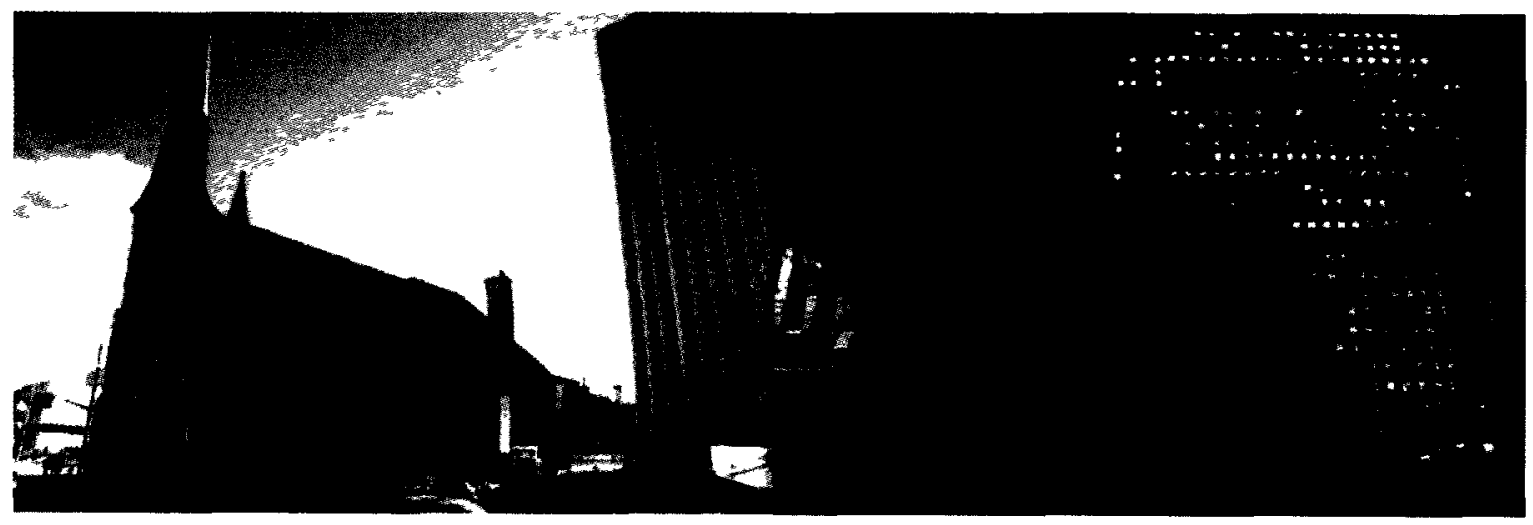

Fig. 28: Day and night conditions from Laurier Street. 


\section{The Proposal \\ Engaging the Voyeurs}

The architectural proposal attempts to address the relationship between voyeurism and society as a way of creating new and innovative perceptual experiences. The mundane and rather regular conditions of the site could be used as an advantage for the building. The proposed voyeuristic architecture incorporates the surrounding apartments and offices that surround the site.

The design proposes a new building to the west of the First Baptist Church and intersecting the Allstream building on Laurier Street. The programmatic elements consist of a swimming pool, a sushi bar, and a fitness studio. The building acts as a civic and public building that is open twenty four hours a day. This addresses the issue of a missing entertainment hub between Elgin Street and Sparks street. Being open twenty four hours also creates the condition of the irregular. The restaurant area can transform into a night lounge or an entertainment hub. Dorothy Kalins from New York Magazine observes that a night lounge or discotheque is a fine balance between voyeurism and exhibitionism. "Men and women indulge in both. Women become more voyeuristic because they are stimulated by the action as dancing increasingly mimics sexuality. ${ }^{75}$ There is amplification of eroticism because the disco generates the thought "Why dance for one partner when everyone in the room is looking at me and I can move for all of them?"76 At night, the transparent façades provide a glimpse for residents of the neighbouring buildings to peer or gaze inside and watch what occurs inside the building.

The pool and fitness studio intersect the Allstream building. The spaces become a point of entertainment for workers of the Allstream building and to the public. The pool becomes voyeuristic in the sense that office workers look down into these spaces during their working hours and gaze upon the swimmers. The pool is designed aboveground and adjacent to Laurier Street. Anyone can enter from the sidewalk and watch or participate with the swimmers. By making the building publically accessible, participants, users, scenarios and events fluctuate and are continuously changing. It is a way to escape a routine that could become predictable and boring.

75 Dorothy Kalins. "Here’s Looking at You: Voyeurism in New York." New York Magazine 3 Mar. 1969: 40.

76 Kalins, 40. 
This is important for those that live or work in the neighbouring buildings; they become voyeurs as they watch the unscripted lives of others unfold. The issue of boundaries develops as participants of the building participate knowing that they can be watched.

But the voyeurism is not just limited to the activities that transpire inside. The architectural detailing of the building is also transparent so that participants learn about the truth of the building and how it is put together. The connections of materials each add to the "exhibitionist" or selfdisclosure nature of the building.

Voyeurism in today's society devalues privacy for the privilege of spectating scenarios, interactions, or discussions of others. In essence, we take away some of the privacy of the participants inside the building. What we end up with is a building that counteracts the mundane or the routine activities within the existing site. It creates a "day and night" condition so to speak. One hopes to generate new and innovative experiences through the civic building's programs, activities, and architectural detailing.

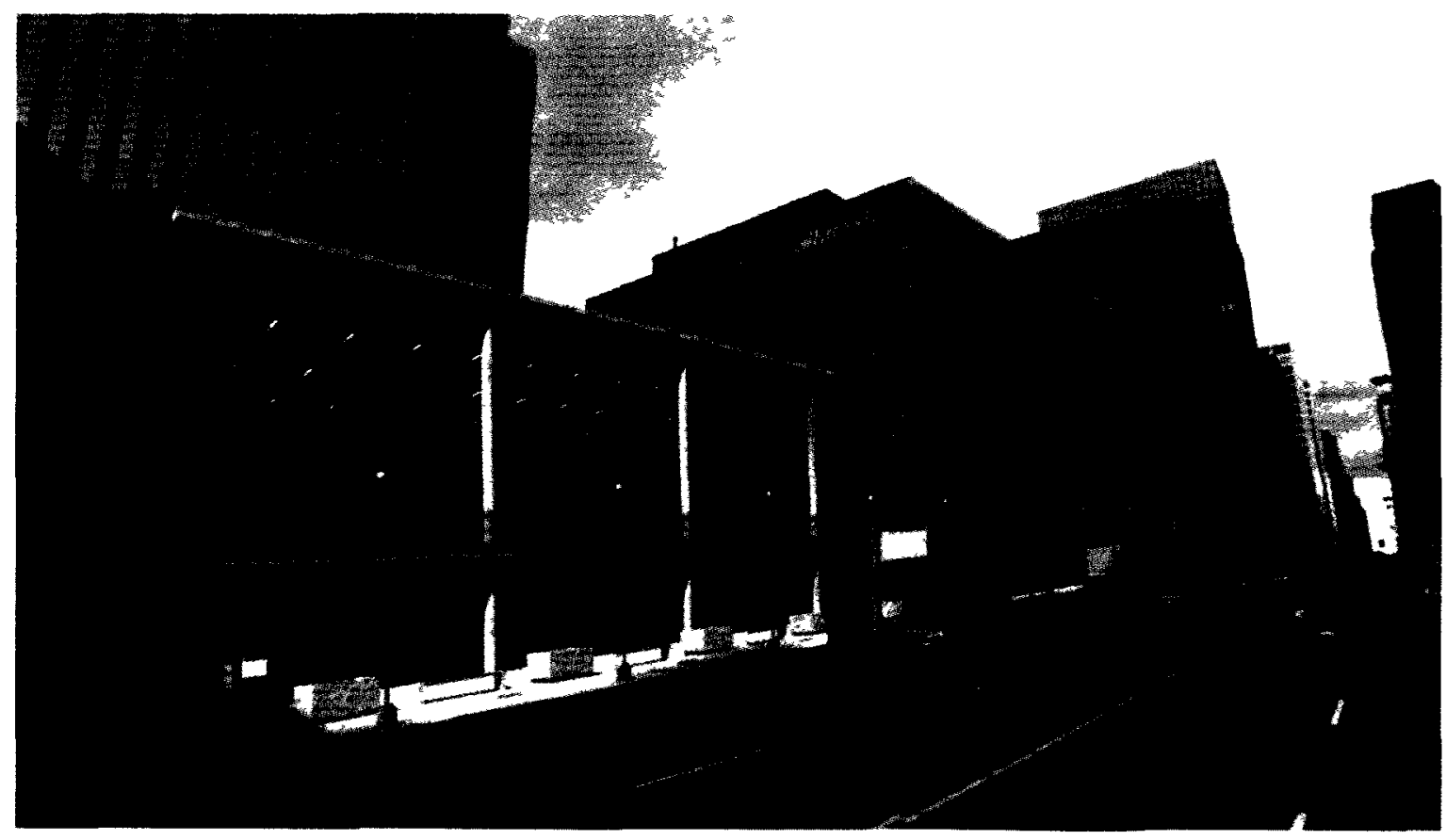

Fig. 29: Elevation from Laurier Street. 


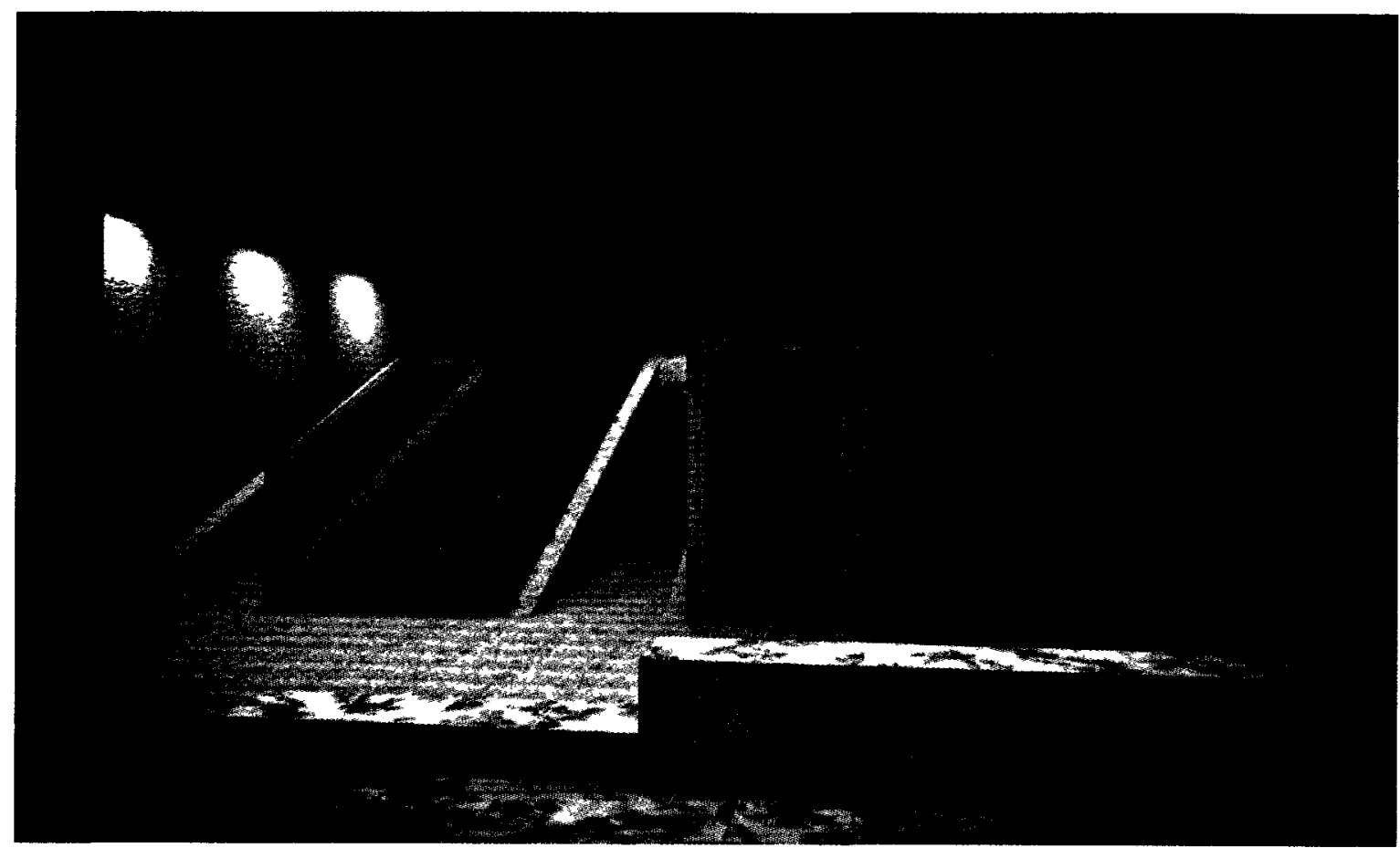

Fig 30: Ground Floor - Main entrance lobby.

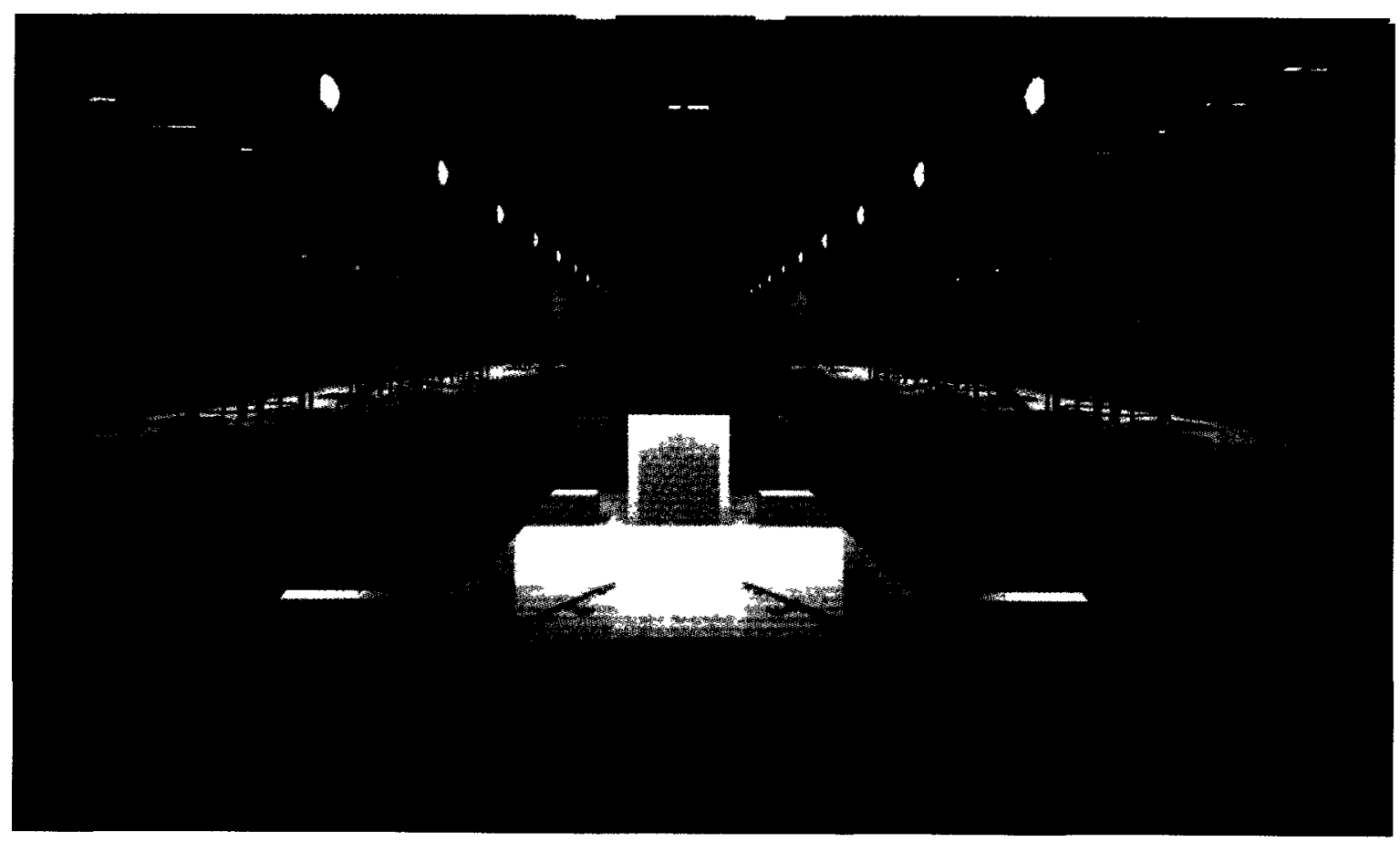

Fig 31: Second Floor - View from stair landıngs 
Earlier, I argued that the North American culture is heavily immersed in voyeurism. The voyeuristic proposal creates a situation where participants are given a sense of security which in turn leads to different levels of vulnerability. Situations where people find themselves in a position of watching, being watched, or unsure of either. The proposal attempts to become the "complementary opposite" of the chosen Ottawa site. The proposal can be considered hedonistic, and the nearby church as the austere. It is active and engaging while the office buildings are considered passive and mundane. The whole proposal revolves around the narrative of the voyeurs and the exhibitionists and the ability to express guilt and shame. Kalins interviewed voyeurs in New York and this is what they had to say about it. "Voyeurism is a holiday, life without risk, an escape into reality. A game with the senses. A way of creating drama, of charging life with extra excitement. A way to break down city loneliness. Everything out there is a play for your benefit."77

The creation of a voyeuristic experience is achieved through consideration of several subject matters. The architecture should possess something along the lines of a mystery. The "mystery of the object" creates curiosity and seduces voyeurs. The design conceives a mystery by proposing activities that contrasts existing conditions on the site in order to seduce the nearby workers and inhabitants. The recreational and athletic activities serve as scenarios for the "real and unguarded lives" that are for the purpose of entertainment.

The activities trifle with the boundaries of public and private. A voyeuristic architecture caters to the accepted notion that society has a thirst for sensational details, events, and lives. Thus, a voyeuristic architecture questions society's notion of what becomes public and private. The essential thing to a voyeur is that he (or she) must believe that the object must "never know that the concept of privacy has broken down. Once she acknowledges that, he [or she] loses pleasure in watching."78 Conversely, exhibitionists expose themselves in public because there is something in that public to react to. Whether it is the stolen glances, the double take, or the guilty pleasure.

The power to control what is private can shift between the voyeur and the exhibitionist if given a gateway. The voyeur chooses what he or she sees, and conversely, the exhibitionist chooses what he or she reveals. 'This power can have a profound effect on society's lifestyle as the "Peeping 


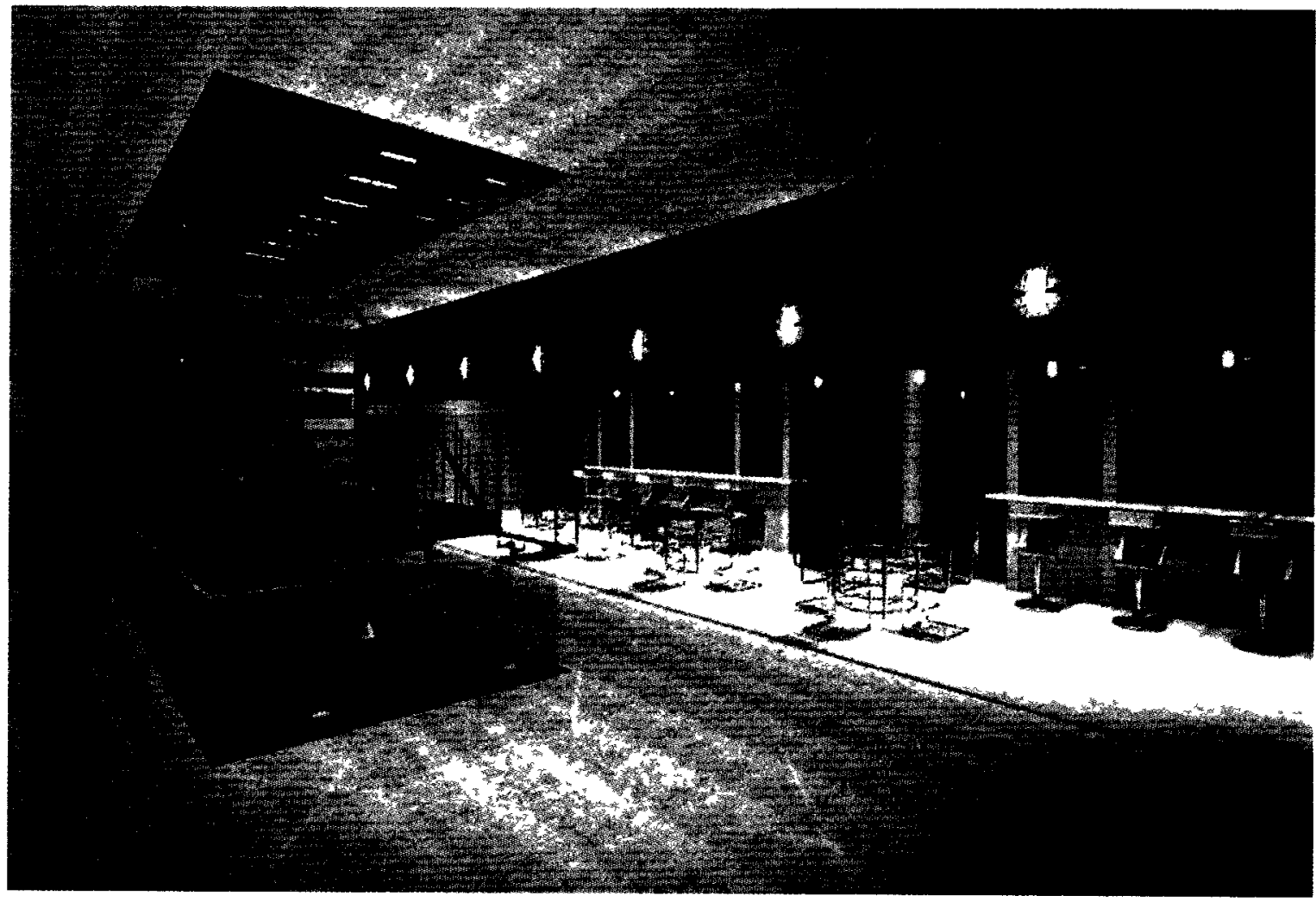

Fig. 32: View of hallway and sushi bars.

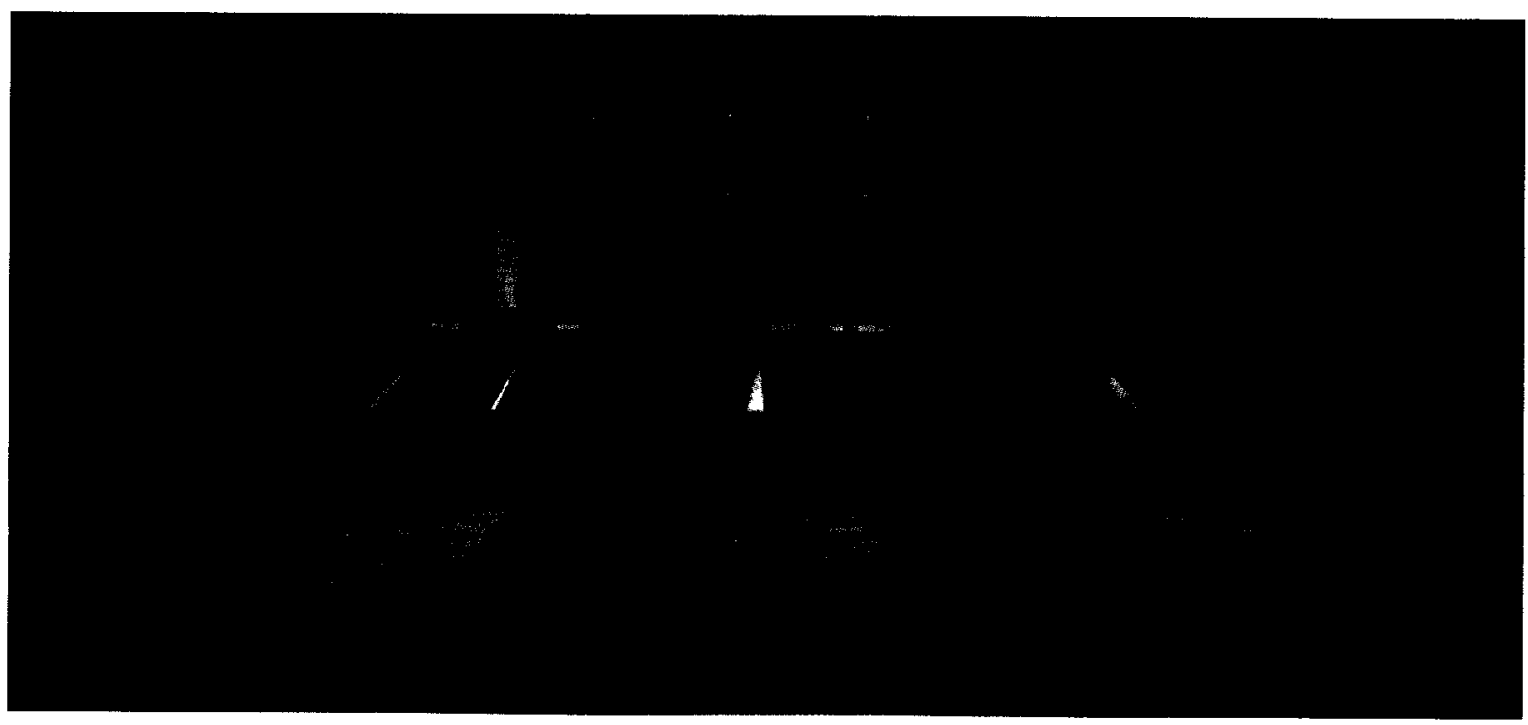

Fig. 33: Sushi bar. 
Tom" effect can be viewed either negatively or positively. This thesis aims to view voyeurism in a positive light for both participants and spectators and voyeuristic experiences are enabled by obscuring ideas of personal boundaries between the two. The objects, or people being observed, must remain strangers for the voyeur so that they may attach fantasies and identities to the object.

It is important to understand that voyeurism is not limited to being sexual in nature. A voyeuristic architecture enables a place to learn or encounter new and innovative perceptual experiences. Voyeurism is not just about the explicit view; it is also about the observation and the stimulation one experiences in seeing or getting what normally would be withheld. 


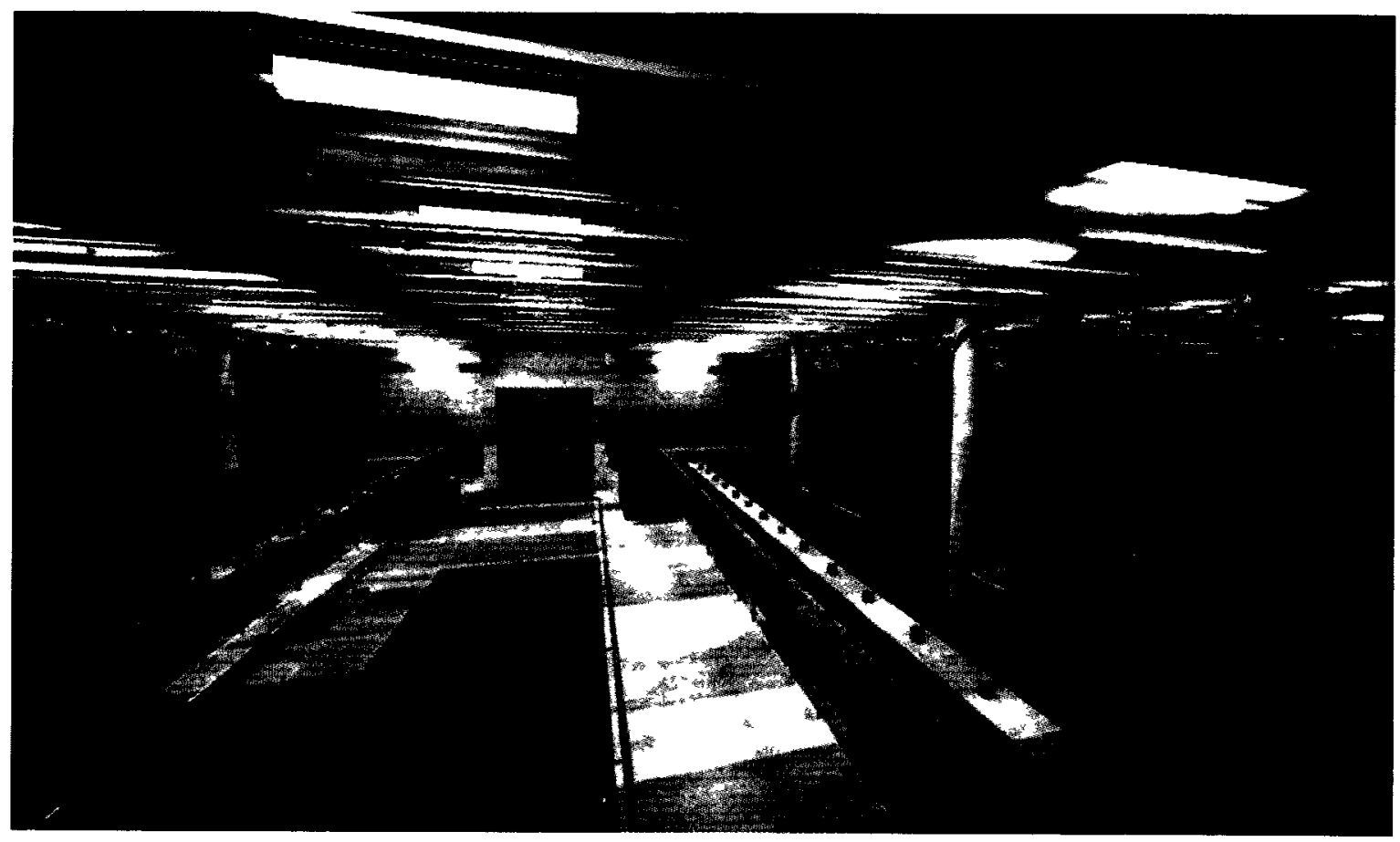

Fig. 34: Third floor - Circulation.

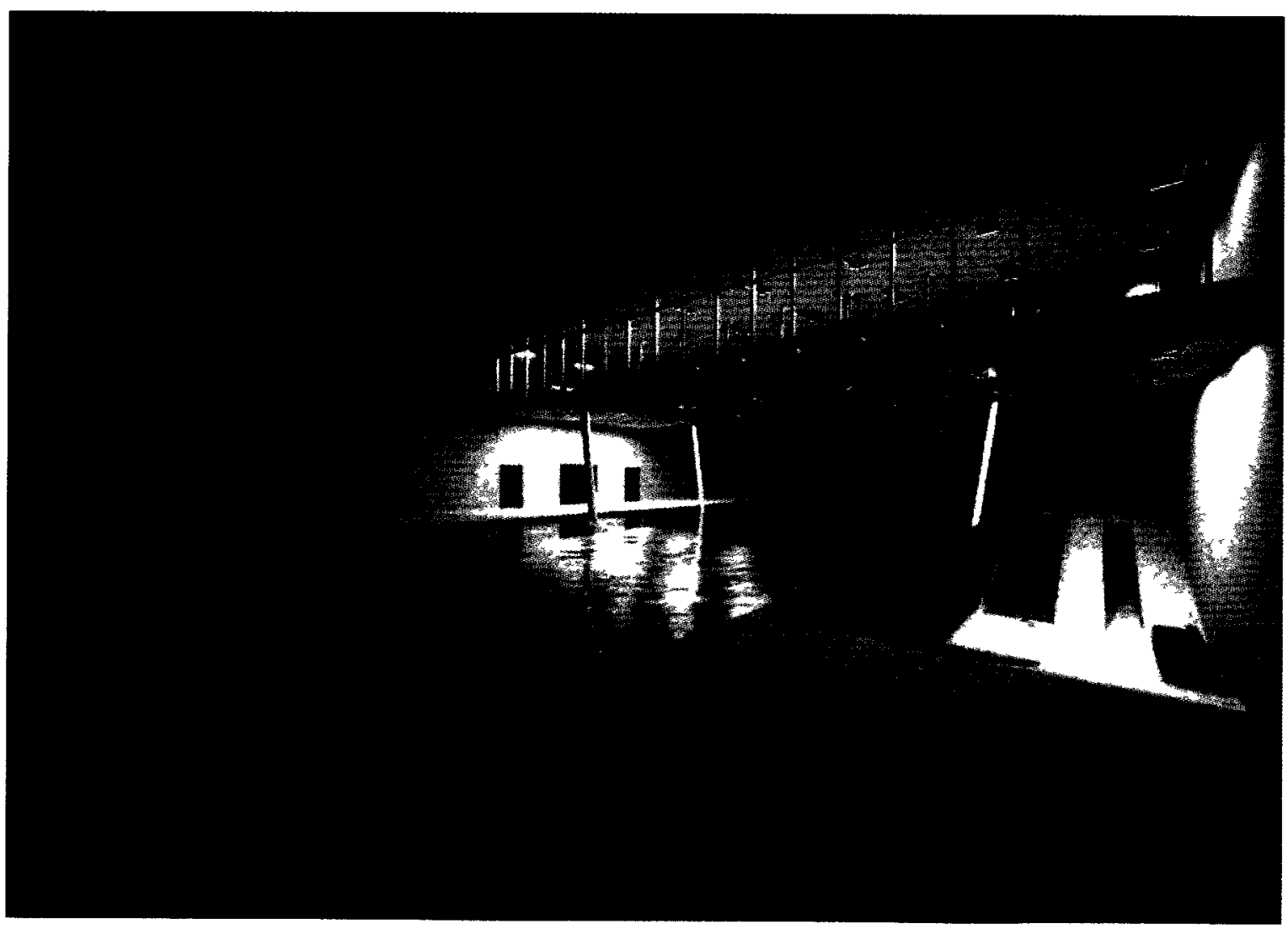

Fig. 35: Public swımming pool with fitness facility above. 


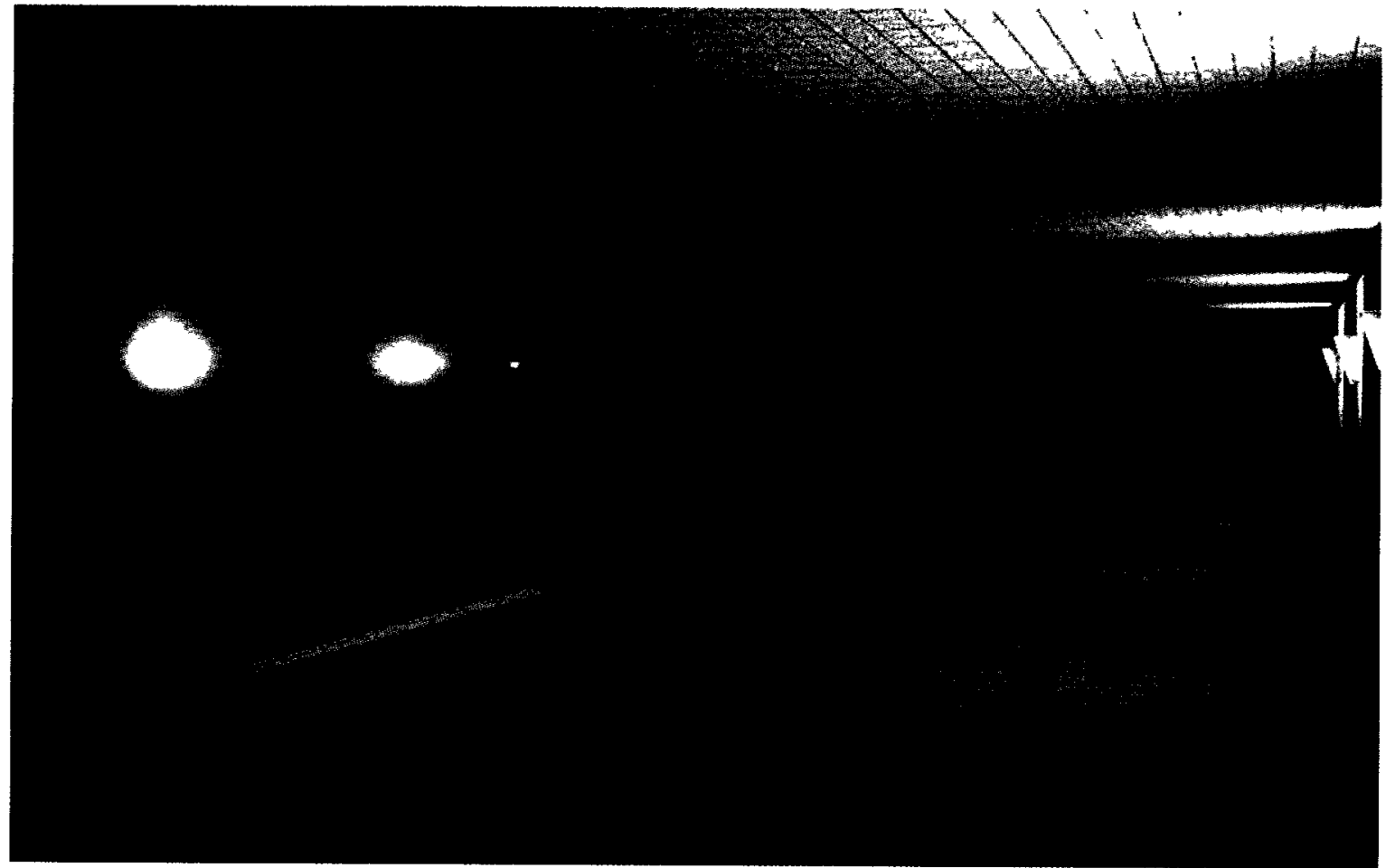

Fig. 36: Ground Floor - Hallway for public visitors.

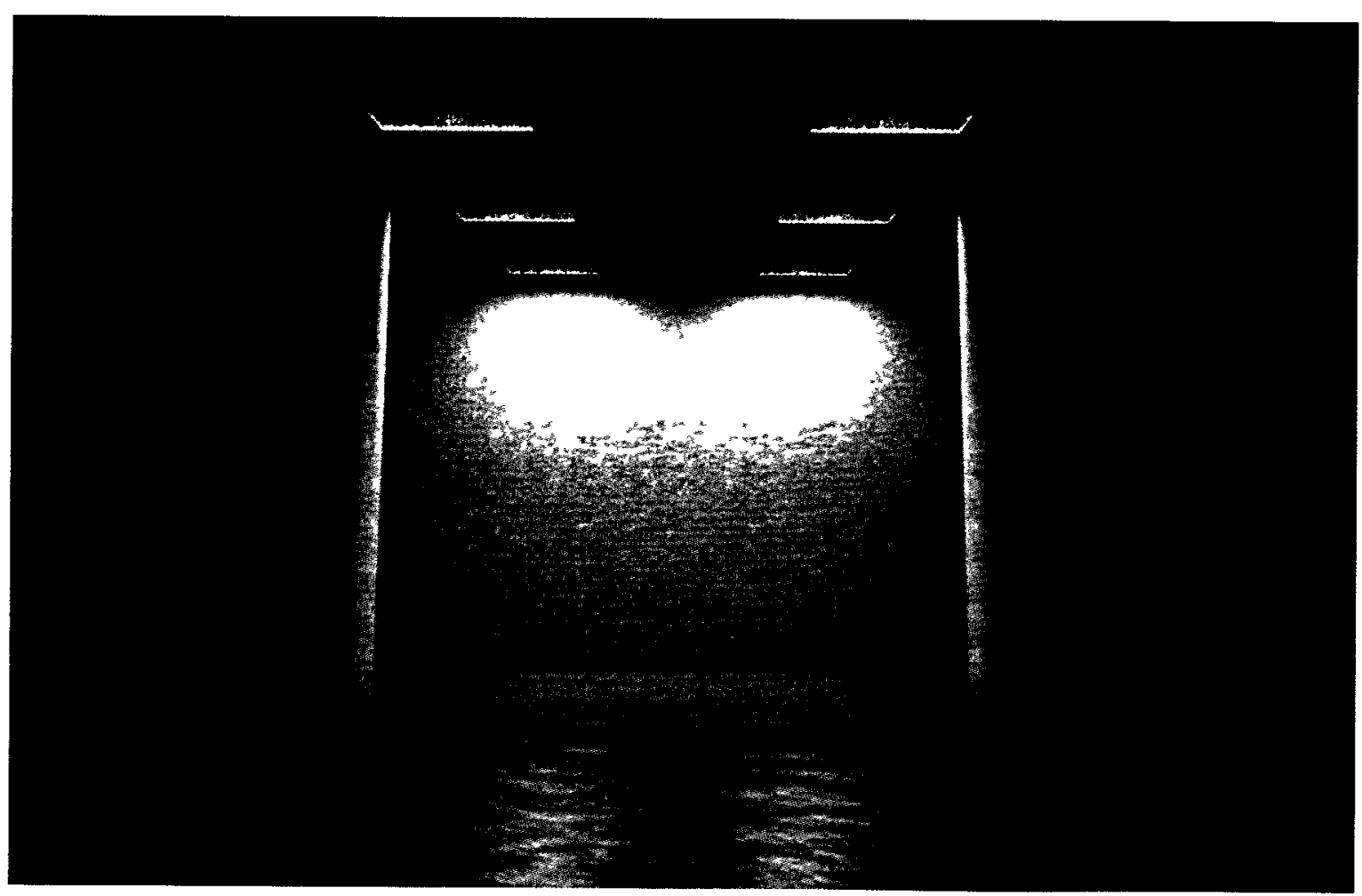

Fig. 37: Columns extend downwards inside the swimming pool. 


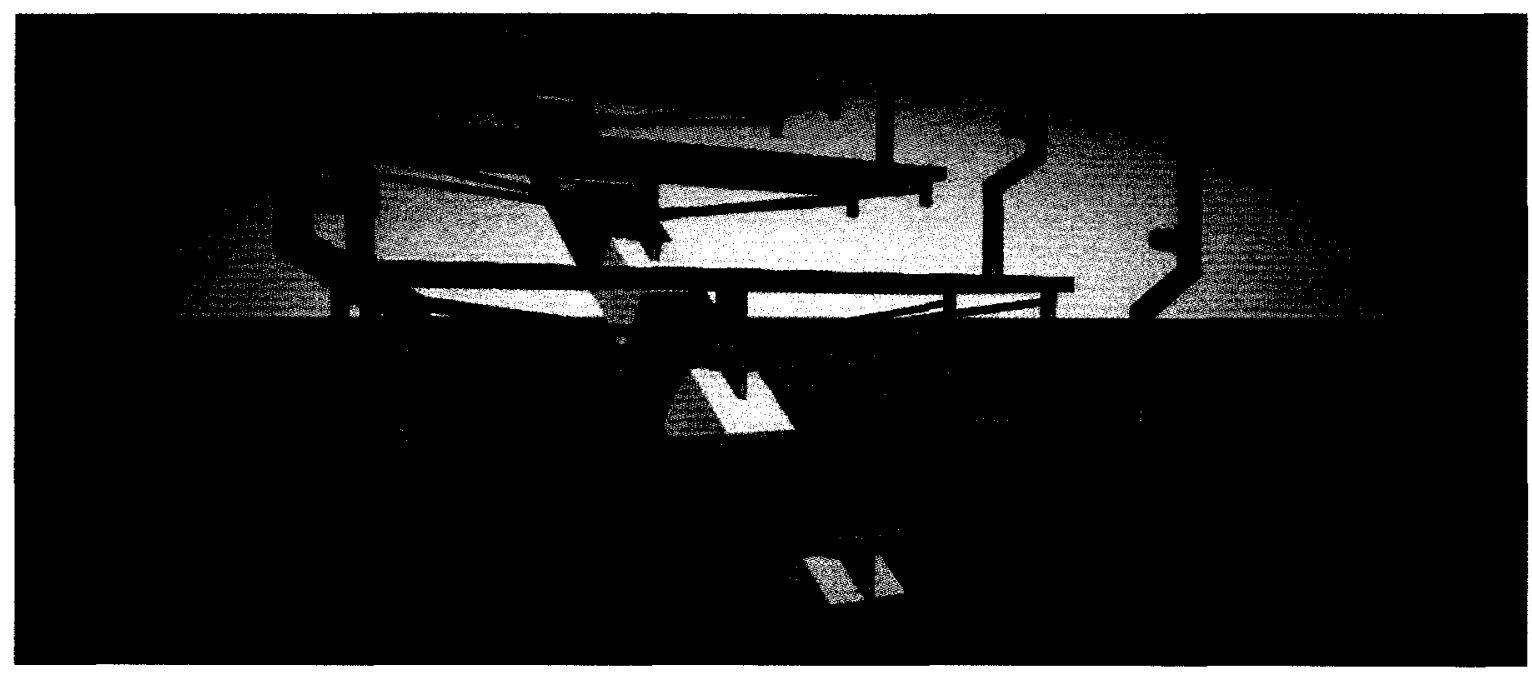

Fig. 38: Typical stair detail: Glass treads, steel rod supports connected to a steel plate. Steel plate connects to a steel beam. Aluminum balusters with glass panels.

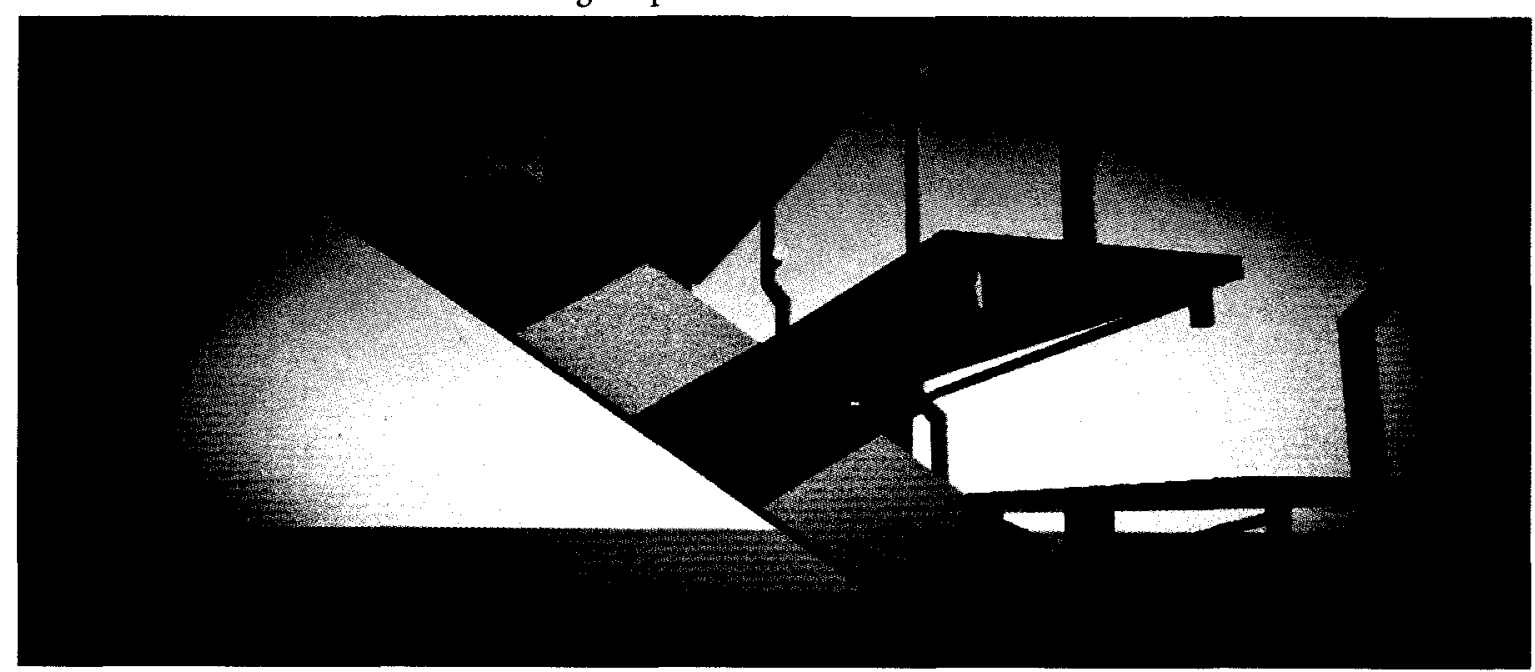

Fig. 39: Stair Detail - Angle view.

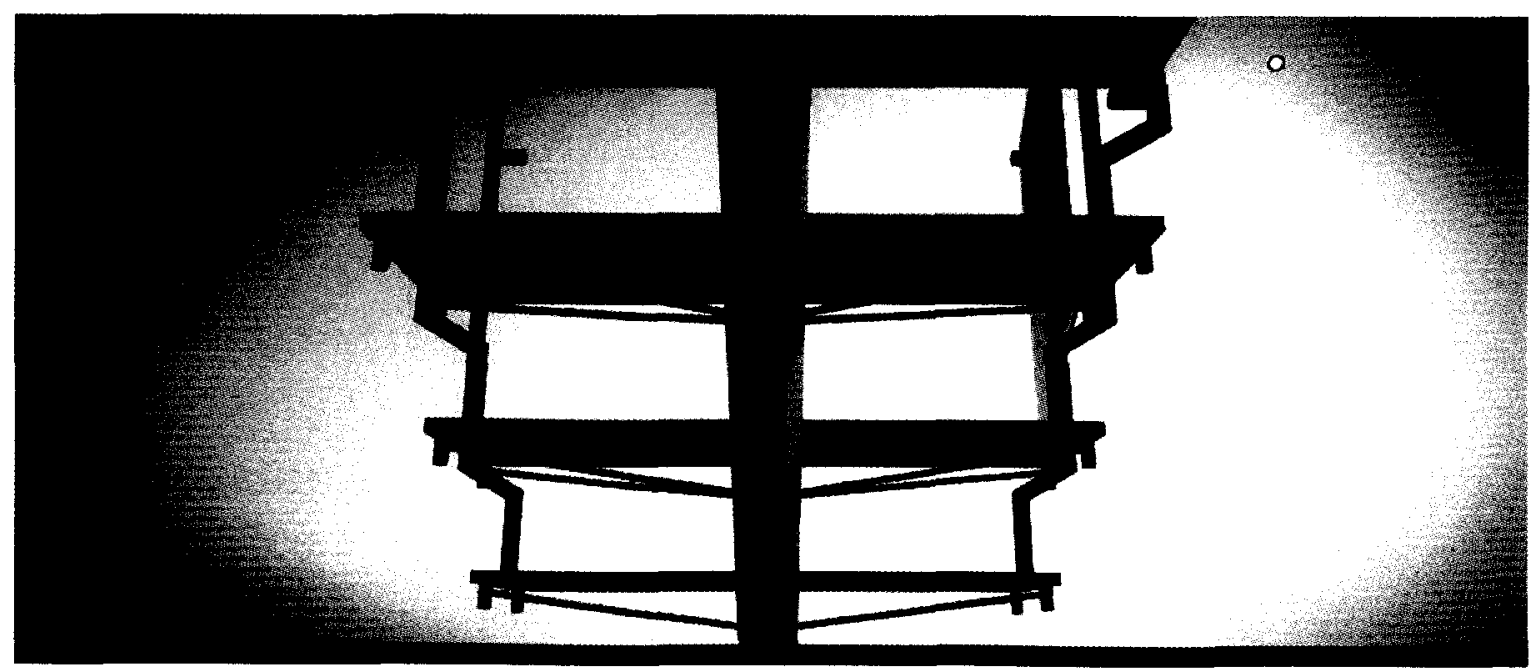

Fig. 40: Stair Detail - Bottom view. 


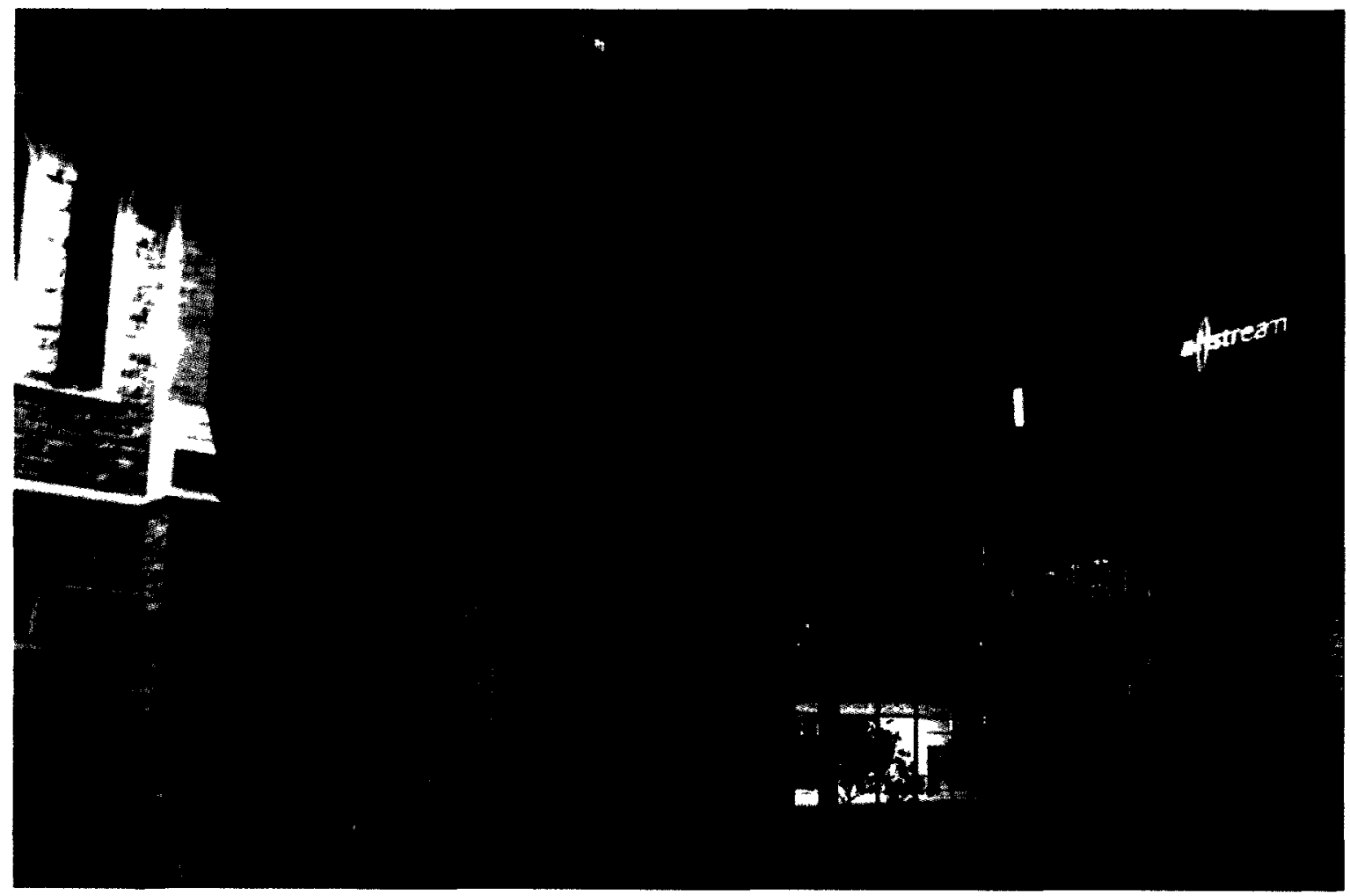

Fig. 41: Elevation at night.

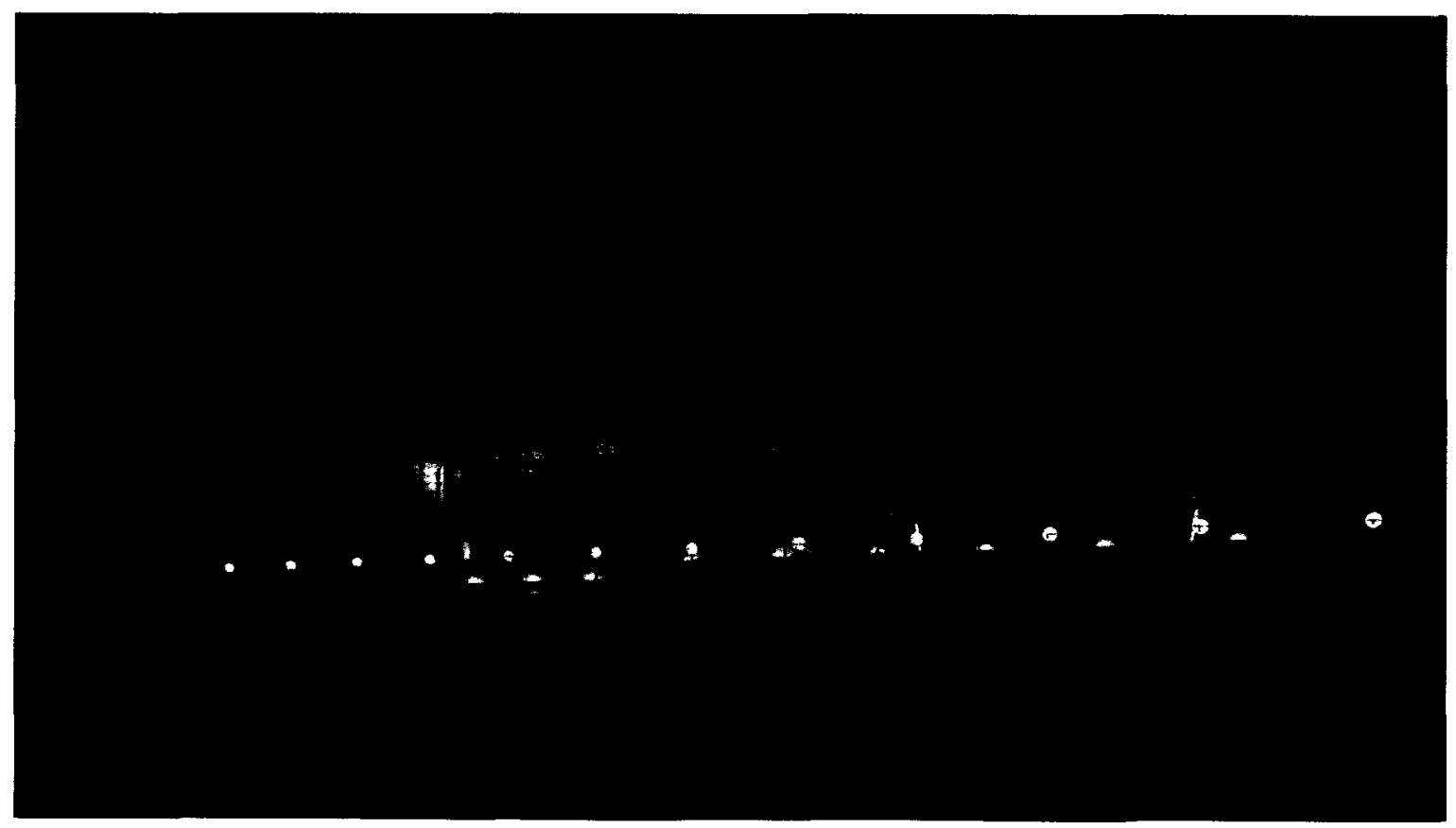

Fig. 42: Elevation showing illumination at night. 


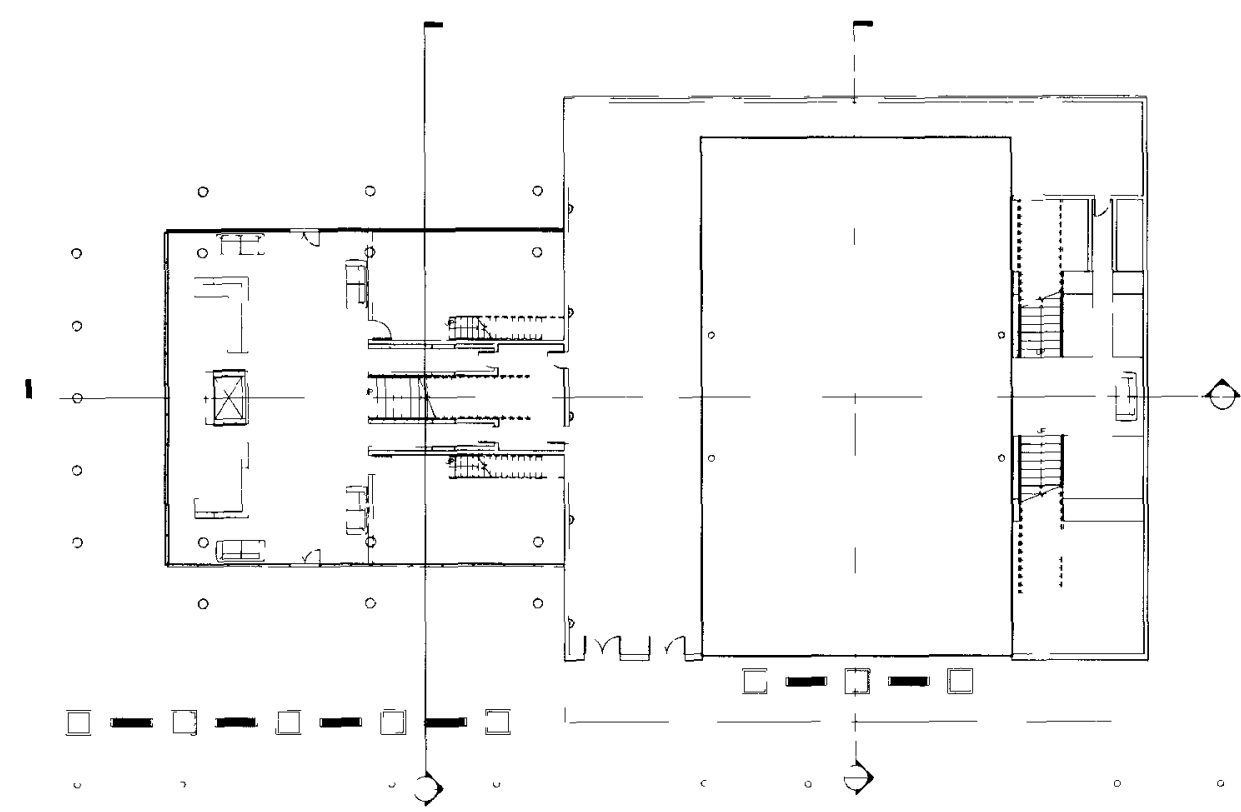

Fig. 43: First floor plan.

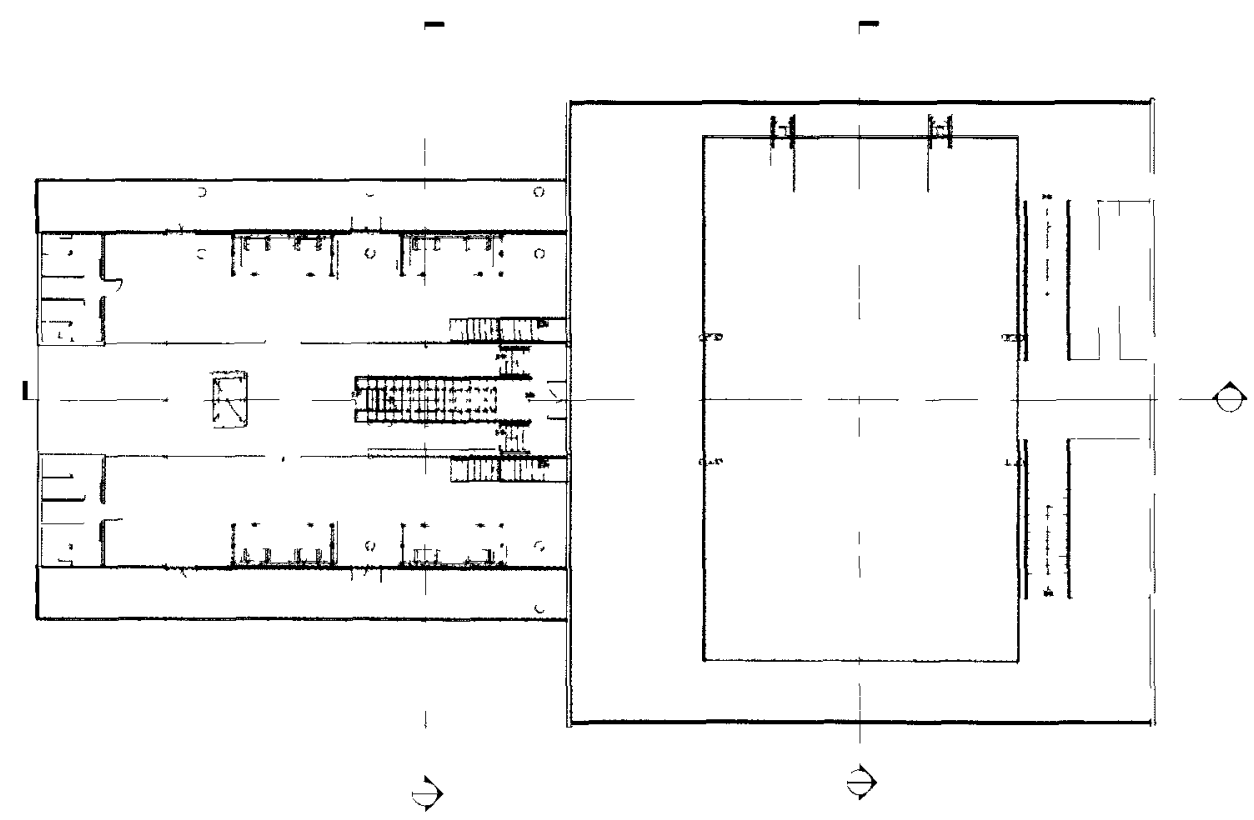

Fig. 44: Second floor plan. 


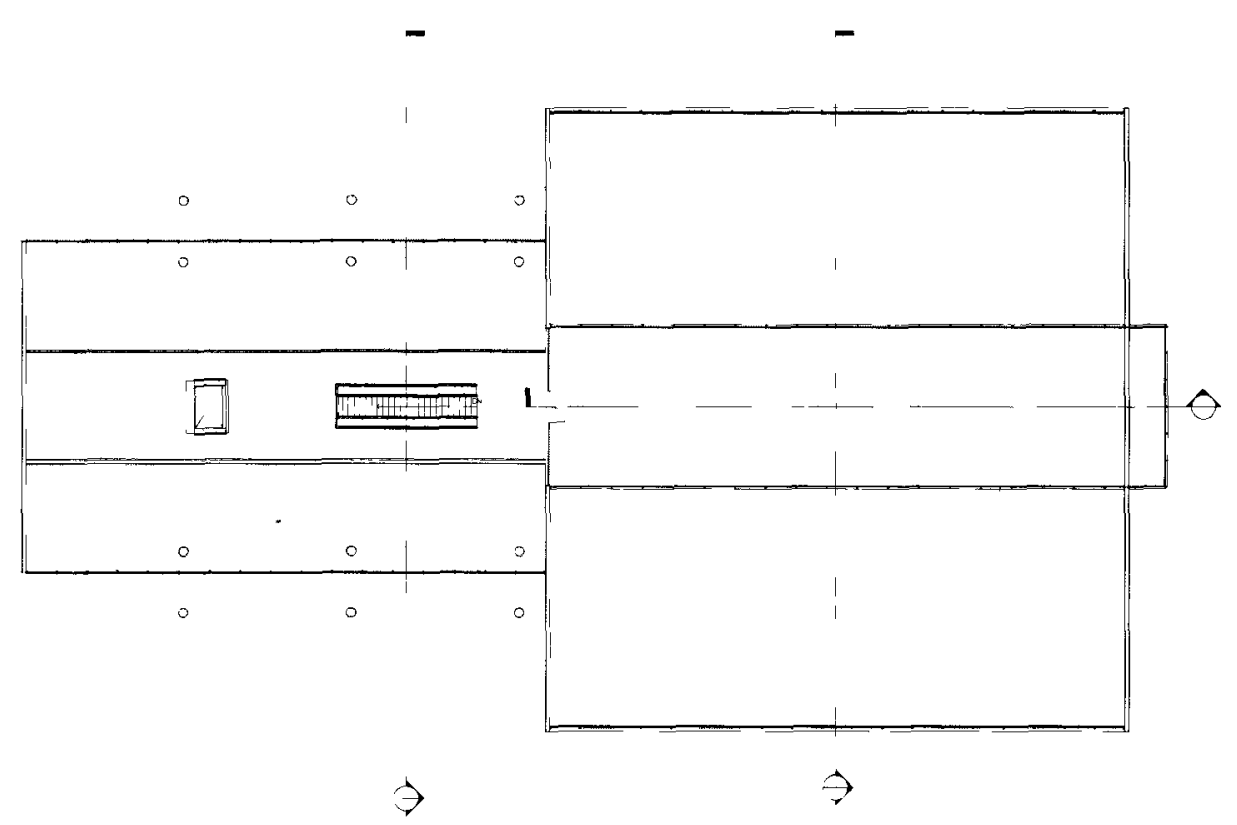

Fig. 45: Third floor plan.

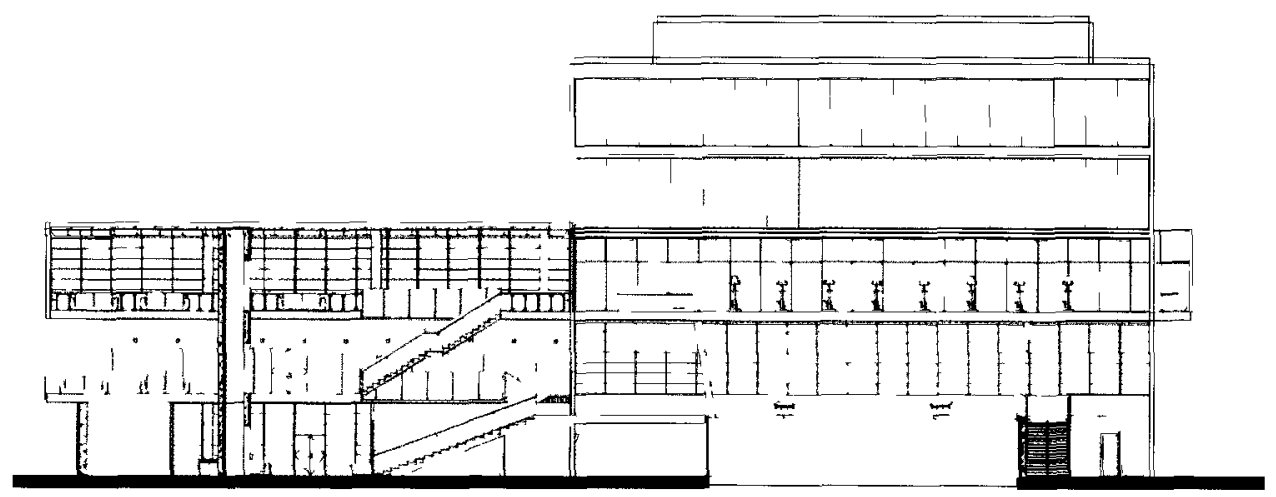

Fig. 46: Longitudinal Section. 


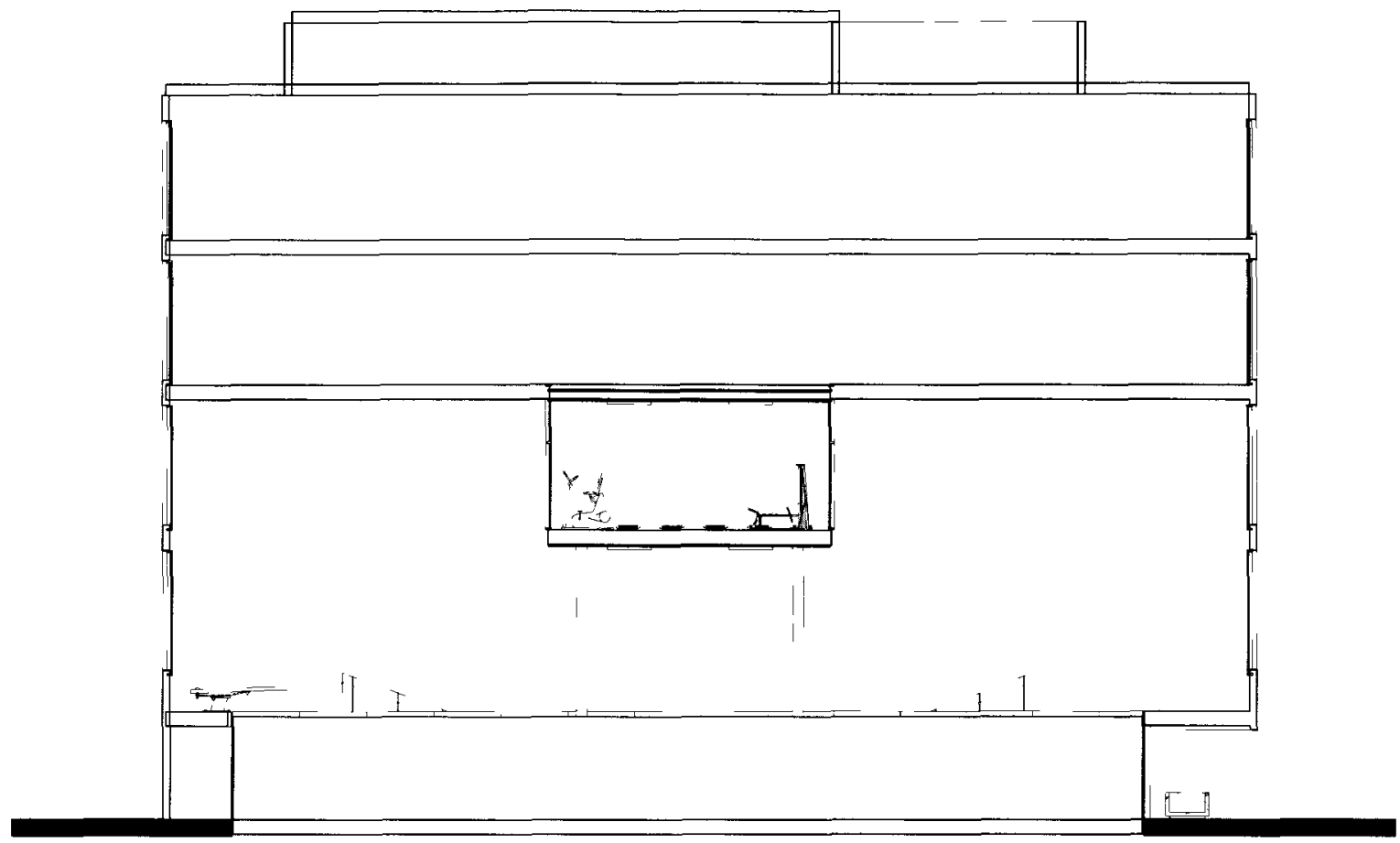

Fig 47 Section through public pool and Allstream office buldıng
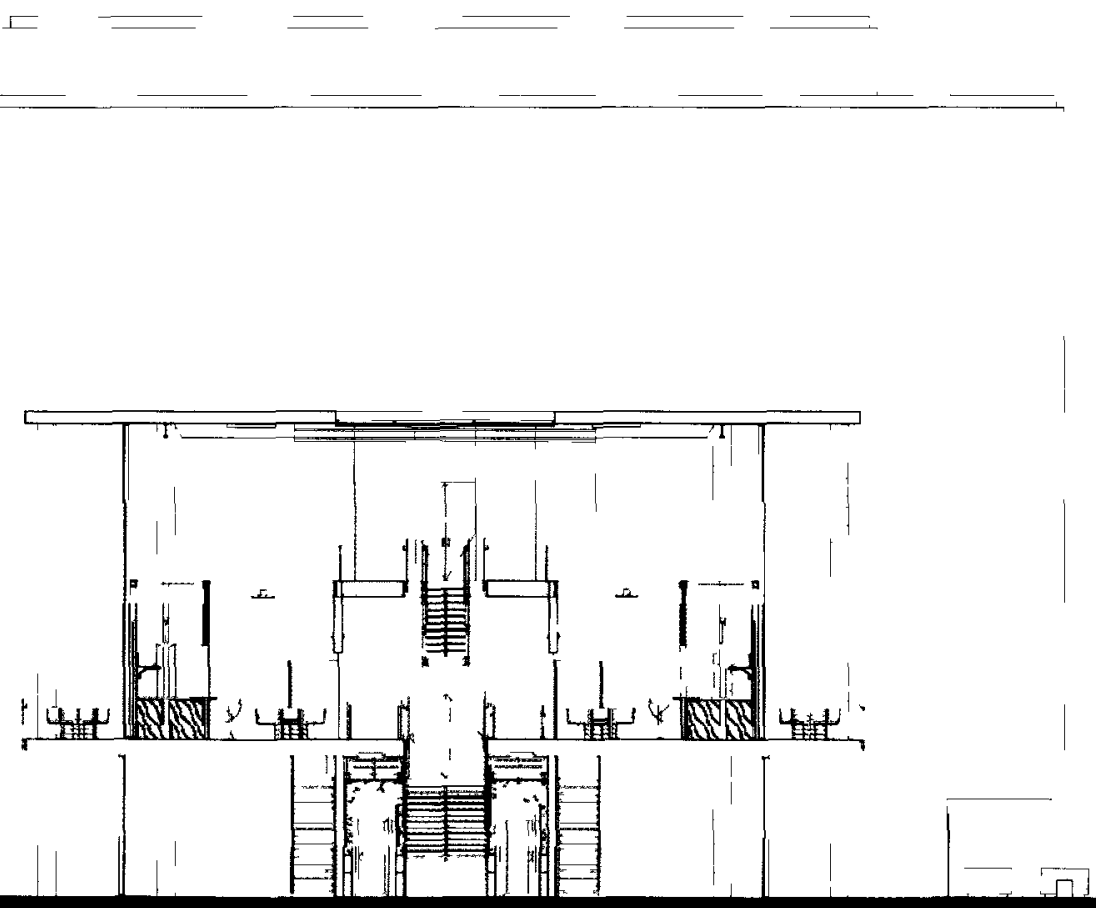

Fig 48 Section through restaurant and main lobby. 


\section{Appendix}

Process Work
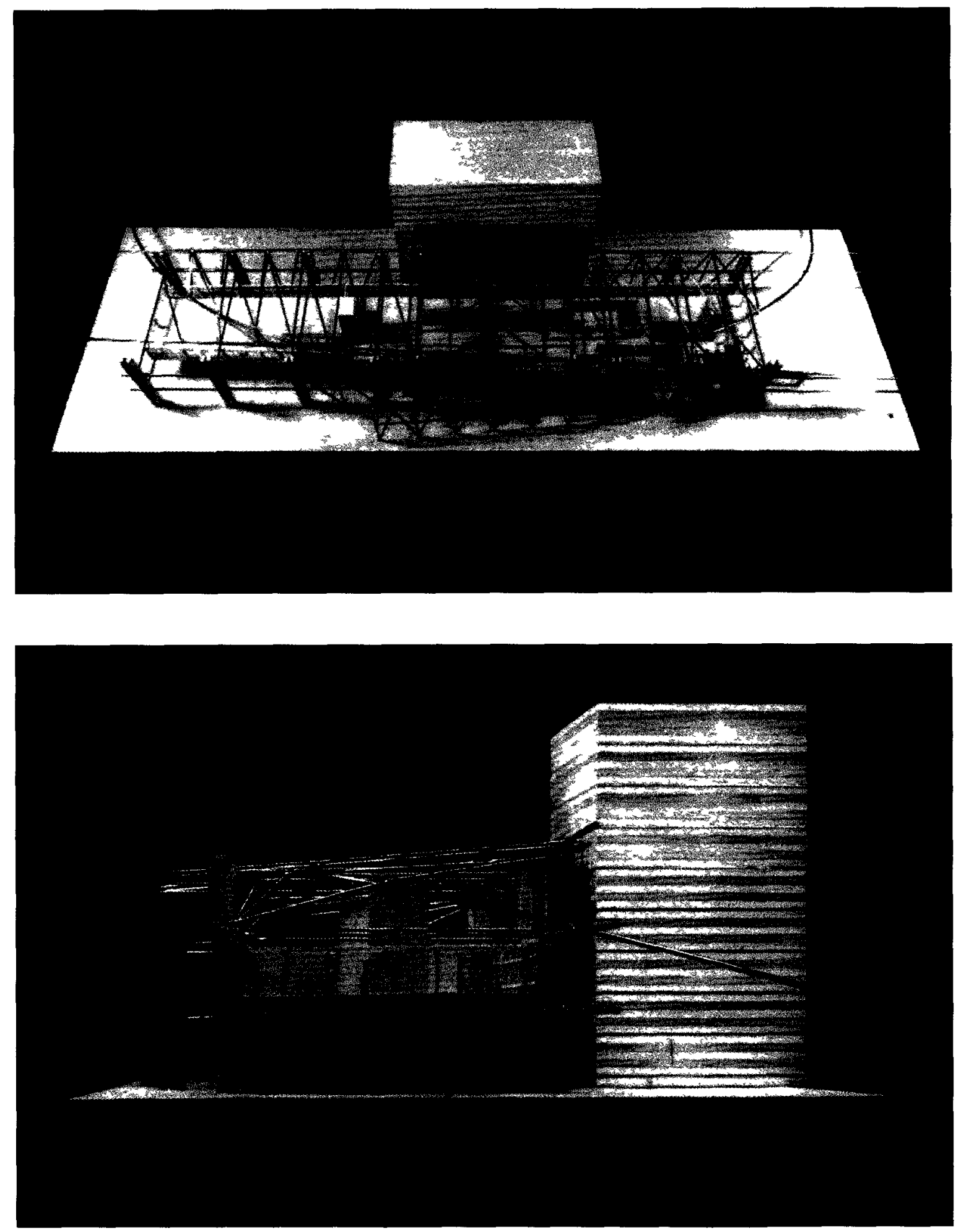

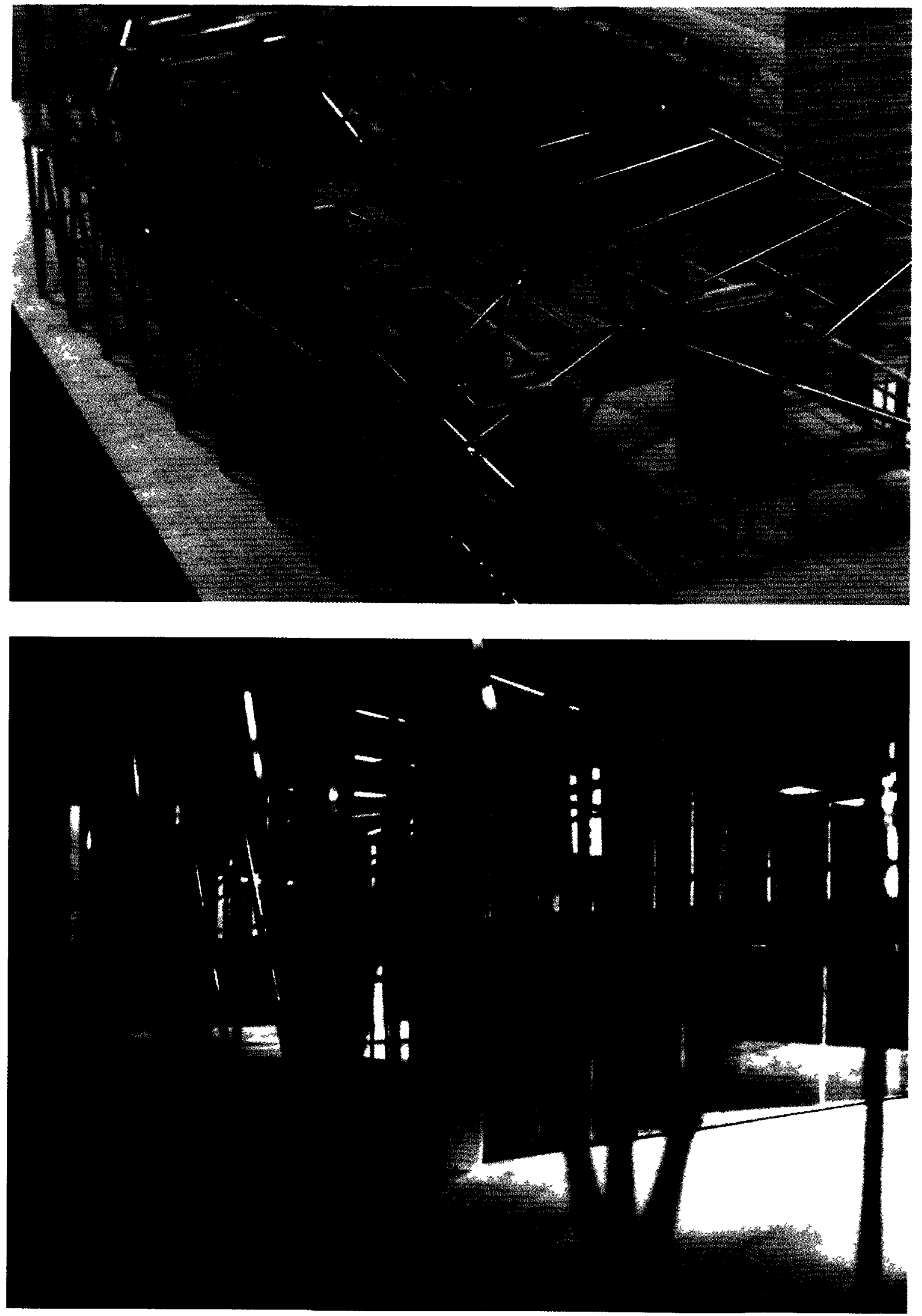

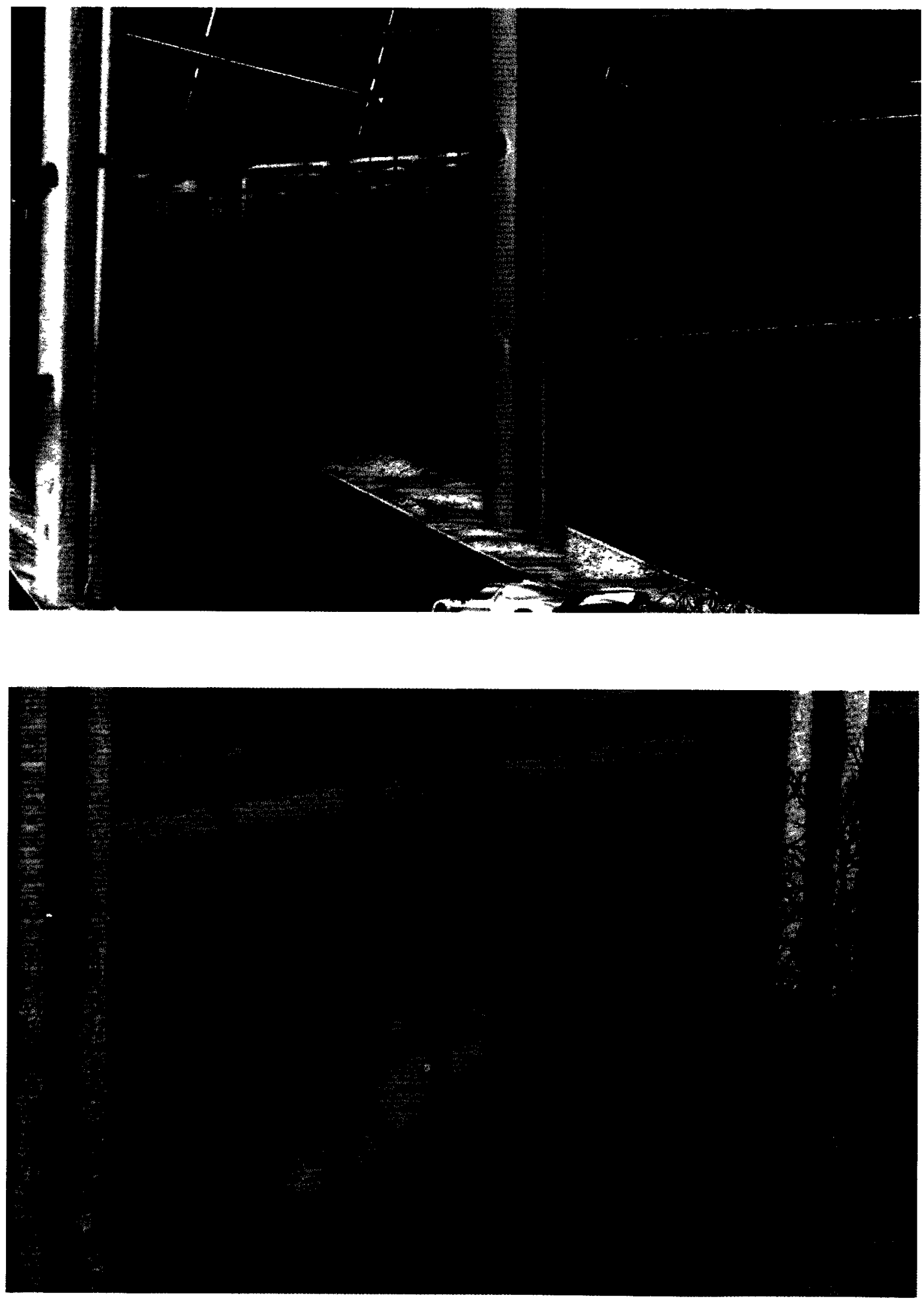

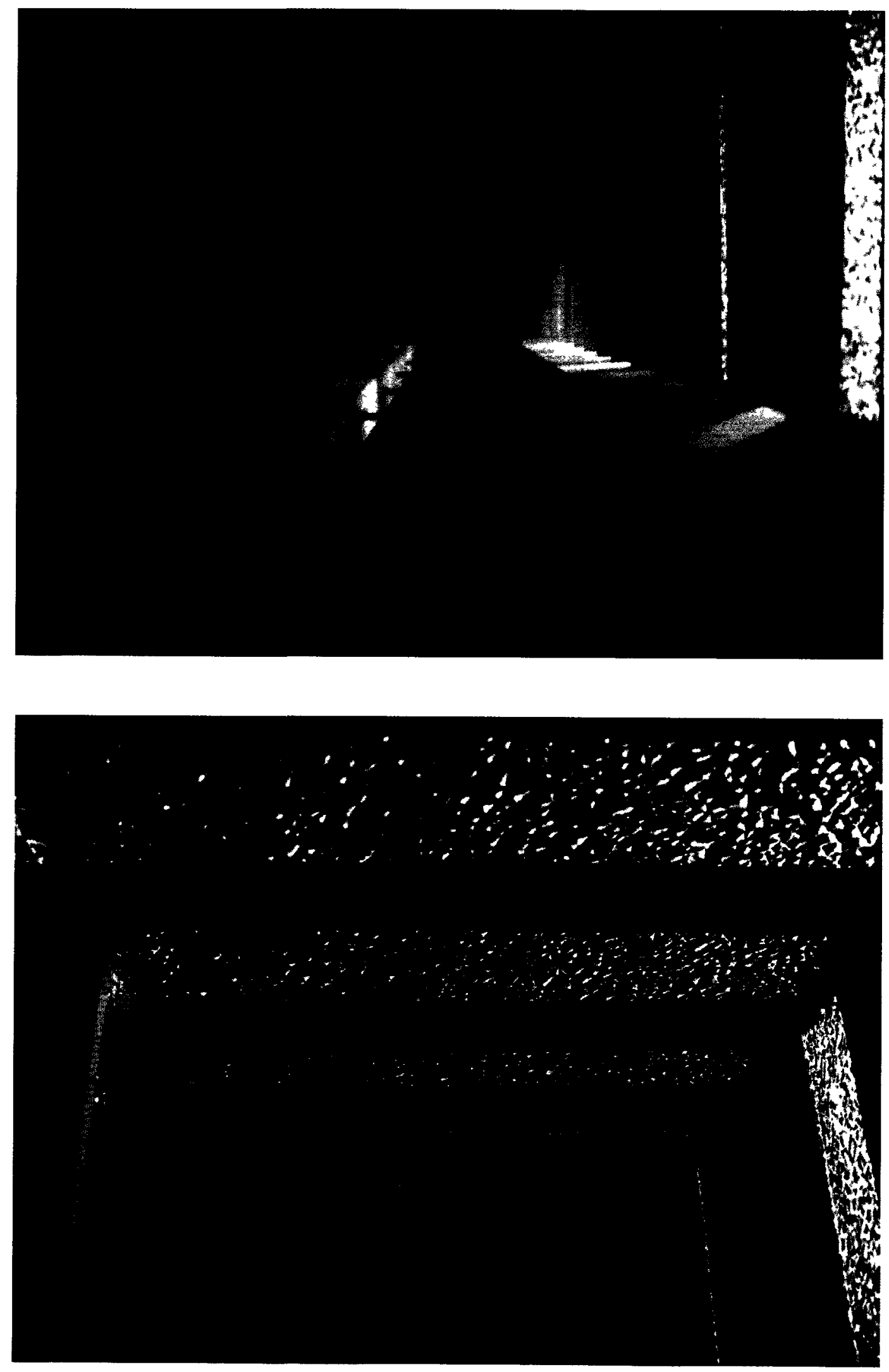


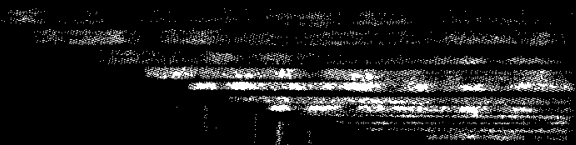

.
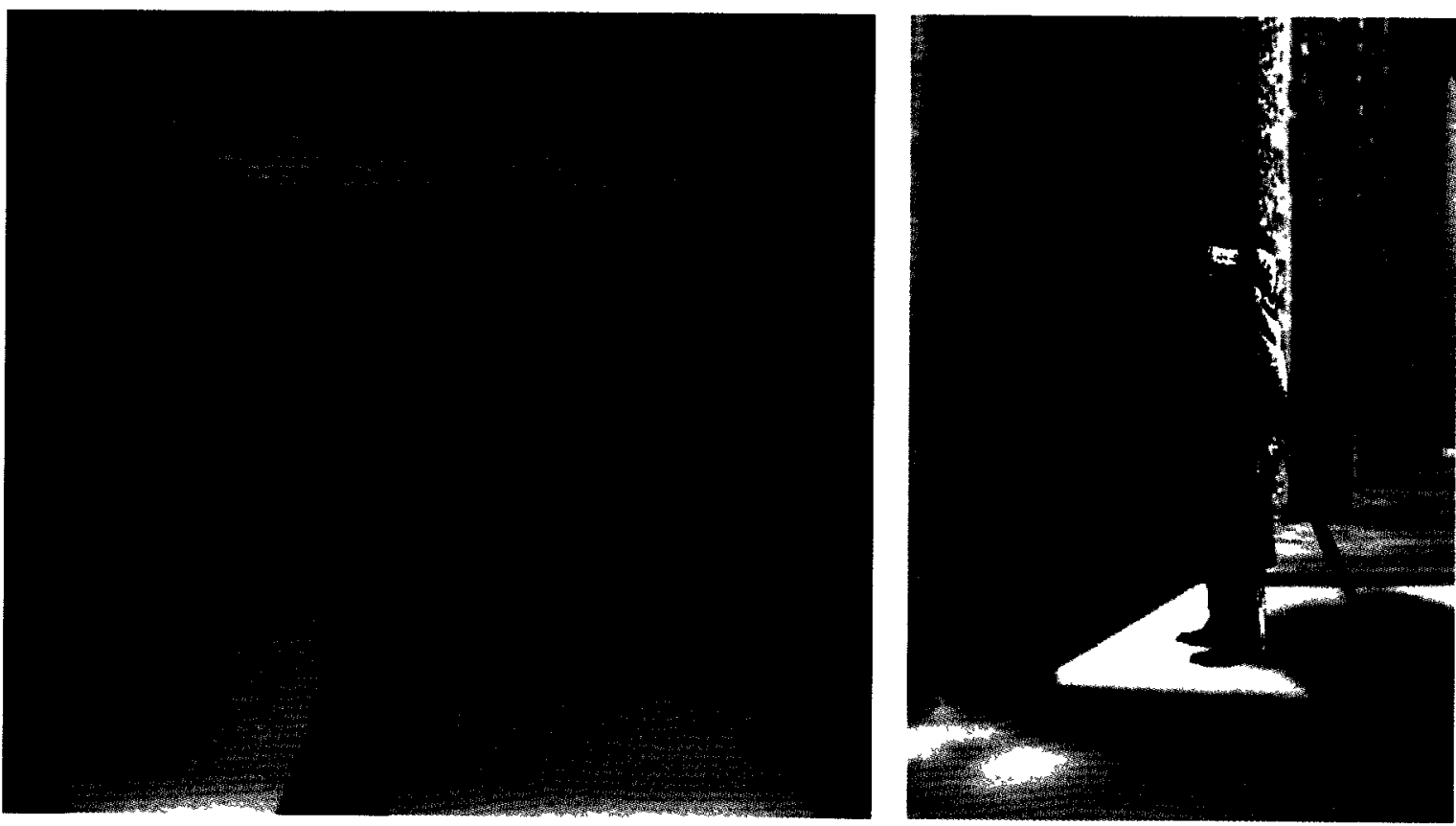


\section{Bíbliography}

1. "AMP Arquitectos." AMP Arquitectos. Web. 6 Dec. 2010. <http://www.amparquitectos.com>.

2. Blue Velvet. Dir. David Lynch. Perf. Kyle MacLachlan. De Laurentiis Entertainment Group (DEG), 1986. DVD.

3. Burgin, Victor. "Perverse Space." Sexuality \& Space. New York: Princeton Architectural, 1992. 219-40. Print.

4. Calvert, Clay. Voyeur Nation: Media, Privacy, and Peering in Modern Culture. Boulder, CO: Westview, 2000. Print.

5. Carson, Anne. Eros the Bittersweet: an Essay. Princeton, NJ: Princeton UP, 1986. Print.

6. Colomina, Beatriz. "The Split Wall: Domestic Voyeurism." Sexuality \& Space. New York: Princeton Architectural, 1992. 73-128. Print.

7. Cotter, Holland. "Landscape of Eros, Through the Peephole." The New York Times. 27 Aug. 2009. Web. 7 Nov. 2010

8. Donoghue, Daniel. Lady Godiva: a Literary History of a Legend. Malden, MA: Blackwell Pub., 2003. Print.

9. El-Dahdah, Fares. “The Josephine Baker House: For Loos's Pleasure.” Assemblage 26 (1995): 72-87. Print.

10. Ebert, Roger. "My Problem with "Blue Velvet." Rogerebert.com. Web. 11 June 2011. <http://rogerebert. suntimes.com/apps/pbcs.dll/article?AID=/19861002/PEOPLE/41216001>.

11. Foucault, Michel. Discipline and Punish: the Birth of the Prison. New York: Vintage, 1995. Print.

12. Foucault, Michel. "Space, Knowledge, and Power." Ed. Paul Rabinow. Architecture Theory Since 1968. Ed. K. Michael. Hays. Cambridge, Mass: MIT, 1998. 436-37. Print.

13. Hollier, Denis. Against Architecture: the Writings of Georges Bataille. Cambridge, MA: MIT, 1989. Print.

14. Jormakka, Kari. "The Most Architectural Thing." Surrealism and Architecture. London: Routledge, 2005. 290-313. Print. 
15. Kalins, Dorothy. "Here's Looking at You: Voyeurism in New York" New York Magazine. 3 Mar. 1969: 3440. Print.

16. Kuspit, Donald. "A Critical History of 20th-Century Art." Artnet - The Art World Online. Web. 10 Nov. 2010. <http://www.artnet.com/magazineus/features/kuspit/kuspit3-17-06.asp>.

17. Kuspit, Donald. “The Troubling Nude”" Artnet - The Art World Online. 11 Mar. 1999. Web. 10 Nov. 2010. <http://www.artnet.com/magazine/features/kuspit/kuspit11-3-99.asp>.

18. Kuspit, Donald. “The Unempathic Eye." Artnet - The Art World Online. 19 Oct. 2001. Web. 8 Nov. 2010. <http://www.artnet.com/magazine/features/kuspit/kuspit10-19-01.asp>.

19. “Lady Godiva." Historic UK. Web. 05 May 2011. <http://www.historic-uk.com/CultureUK/LadyGodiva. htm>.

20. "Lady Godiva: The Naked Truth." BBC News. Web. 05 May $2011 .<$ http://news.bbc.co.uk/2/hi/in_depth/ uk/2000/newsmakers/1507606.stm>.

21. Loos, Adolf. "Ornament and Crime." Programs and Manifestoes on 20th-century Architecture. Cambridge, MA: MIT, 1971. 19-24. Print.

22. Marquis, Alice Goldfarb., and Marcel Duchamp. Marcel Duchamp, the Bachelor Stripped Bare: a Biography. Boston: MFA Publications, a Division of the Museum of Fine Arts, Boston, 2002. Print.

23. Meis, Morgan. “The Smart Set: Peep Show." The Smart Set. 7 Oct. 2009. Web. 12 Dec. 2010. <http://www. thesmartset.com/article/article10060901.aspx>.

24. Moure, Gloria, and Marcel Duchamp. Marcel Duchamp: Works, Writings and Interviews. Barcelona: Ediciones Poligrafa, 2009. Print.

25. Perez, Gomez Alberto. Polyphilo, Or, The Dark Forest Revisited: an Erotic Epiphany of Architecture. Cambridge, MA: MIT, 1992. Print.

26. Pérez-Gómez, Alberto. Built upon Love: Architectural Longing after Ethics and Aesthetics. Cambridge (Mass.): MIT, 2006. Print.

27. Philly. Dir. Hannah Wilke. Perf. Hannah Wilke. Electronic Arts Intermix, 1977. Videocassette. 
28. Piper, Adrian. "Art as Fetish: Adrian Piper." Ed. Thomas E. Wartenberg. The Nature of Art: An Anthology. Fort Worth: Harcourt College, 2002. 253-64. Print.

29. Quart, Leonard. "20 Years Later, Blue Velvet Is Surreal as Ever." Downtown Express. Web. 11 June 2011. $<$ http://www.downtownexpress.com/de_148/20yearslaterblue.html $>$.

30. Schittich, Christian. Building in Existing Fabric: Refurbishment, Extensions, New Design. München: Edition Detail, 2003. Print.

31. Stafford, Andrew. "Making Sense of Marcel Duchamp." Making Sense of Marcel Duchamp. 2008. Web. 07 Jan. 2011.<http://understandingduchamp.com/text.html\#1923>.

32. Walsh, Meeka. "The Gaze and the Guess: Fixing Identity in Étant Donnés." Border Grossings 29.2 (2010): 16-17. Print. 